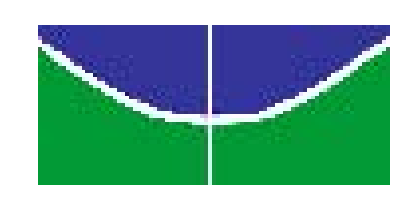

UNIVERSIDADE DE BRASÍLIA - UNB

FACULDADE DE ECONOMIA, ADMINISTRAÇÃO, CONTABILIDADE E CIÊNCIA DA INFORMAÇÃO E DOCUMENTAÇÃO (FACE) MARIA GORETE GUERRA DE QUEIROZ

\title{
ANÁLISE DA GESTÃO ESTRATÉGICA DO STJ NO PERÍODO 2004 - 2008
}


MARIA GORETE GUERRA DE QUEIROZ

\section{ANÁLISE DA GESTÃO ESTRATÉGICA DO STJ NO PERÍODO 2004 - 2008}

Monografia apresentada ao Programa de PósGraduação em Administração (PPGA) da Faculdade de Economia, Administração, Contabilidade e Ciência da Informação e Documentação (FACE), da Universidade de Brasília, como requisito parcial à obtenção do grau de Especialista em Gestão Judiciária.

Orientador: Prof . Aldery Silveira Júnior

Brasília - DF 
Dedico este trabalho,

A meu esposo, que sempre me incentivou e apoiou na caminhada rumo ao crescimento intelectual.

A meus filhos Gabriela e Luiz, aos quais dedico minha vida. 


\section{AGRADECIMENTO}

A Deus, por iluminar os meus caminhos, ajudando-me a vencer todos os obstáculos.

Ao Superior Tribunal de Justiça que patrocinou a minha participação no Curso de Gestão Judiciária na Universidade de Brasília.

Ao Prof. Aldery Silveira Júnior, meu orientador, pela sua atenção e disponibilidade em participar desse momento tão importante de crescimento pessoal e intelectual.

Aos Professores e Colegas do Programa de pós-graduação, pelo empenho, companheirismo e diálogos.

A Maize Silva Ramos, pela inestimável ajuda nos trabalhos de pesquisa que realizamos durante a participação no Curso.

A todos aqueles que, sem serem mencionados, no silêncio, contribuíram na realização do presente trabalho. 


\section{RESUMO}

Este trabalho teve como objetivo avaliar os resultados obtidos na gestão estratégica do STJ, bem como a sua efetividade. Inicialmente, foi realizada uma extensa pesquisa bibliográfica com vistas a explorar os aspectos teóricos e metodológicos inerentes ao processo de gestão estratégica. Foi dedicado um tópico especial ao Balanced Scorecard, ferramenta de gerenciamento e aferição da gestão estratégica, que é utilizada pela Instituição e que permite a avaliação dos resultados da gestão estratégica de forma segmentada e integrada, em função das perspectivas definidas no planejamento. A análise dos resultados foi realizada através de pesquisa documental, tomando-se por base os planos e relatórios de gestão, para o período de 2004 a 2007. O ano de 2008 não foi abrangido pela análise, tendo em vista que o relatório de gestão desse período ainda não está disponível. Mesmo considerando as dificuldades na aferição de alguns indicadores e levando-se em conta o período de abrangência reduzido, foi possível deduzir um quadro avaliativo global para o período sob análise, que retrata não só o efeito da gestão estratégica sobre o desempenho da Instituição, bem como a sua utilização na prática como instrumento capaz de viabilizar o cumprimento de sua missão institucional. A análise dos índices de forma individualizada e consolidada permitiu efetuar conclusões sobre a forma como o processo de gestão estratégica vem sendo conduzida; quanto ao desempenho

global observado no período; e quanto à utilização do Balanced Scorecad como instrumento de avaliação e de subsídio para implementação de ações corretivas com tempestividade.

Palavras-Chaves: Gestão Estratégica, Planejamento Estratégico. 


\section{LISTA DE GRÁFICOS}

Gráfico 1 - Satisfação do usuário externo $\quad 41$

Gráfico 2 - Recorribilidade interna $\quad 42$

Gráfico 3 - Reforma interna da decisão

Gráfico 4 - Redução do impacto ambiental

Gráfico 5 - Número de pessoas beneficiadas pelos projetos de cidadania $\quad 46$

Gráfico 6 - Aumento da produção de julgados $\quad 48$

Gráfico 7 - Índice de redução do passivo $\quad 49$

Gráfico 8 - Processos recursais tramitados no prazo 51

Gráfico 9 - Prazo médio de tramitação 53

Gráfico 10 - Percepção da atuação do STJ 54

Gráfico 11 - Nível de conhecimento

Gráfico 12 - Integrar as informações processuais $\quad 57$

Gráfico 13 - Garantir a apreciação de 80\% dos projetos de lei de interesse do STJ 59

Gráfico 14 - Convergir 100\% dos processos aplicados ao desenvolvimento de pessoas 60 para o modelo de competências

Gráfico 15 - Capacitação de servidores $\quad 61$

Gráfico 16 - Satisfação do servidor 63

Gráfico 17 - Economicidade $\quad 65$

Gráfico 18 - Aplicação dos recursos orçamentários $\quad 66$

Gráfico 19 - Incremento de recursos para investimento $\quad 67$

Gráfico 20 - Custo do processo judicial $\quad 68$ 


\section{LISTA DE QUADROS}

Quadro 1- O animal da estratégia

Quadro 2- Vantagens e desvantagens associadas à estratégias

21

Quadro 3 - Princípio da maior eficiência, eficácia e efetividade . 25

Quadro 4 - Etapas do Planejamento Estratégico 26

Quadro 5 - Um sistema gerencial diferente - Planejamento e estabelecimento de metas.. 28

Quadro 6 - Detalhamento das metas e resultados.

Quadro 7 - Detalhamento das metas e resultados (continuação). 72

Quadro 8 - Consolidação dos resultados por objetivo estratégico. 73

Quadro 9 - Consolidação dos resultados por perspectiva..... 73 


\section{SUMÁRIO}

1 - INTRODUÇÃO ....................................................................................................................................

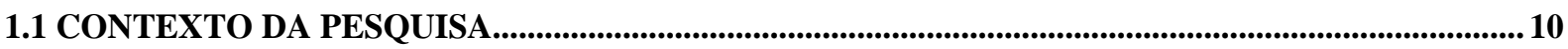

1.2 FORMULAÇÃO DO PROBLEMA DE PESQUISA .................................................................................11

1.3 OBJETIVOS ............................................................................................................................................ 11

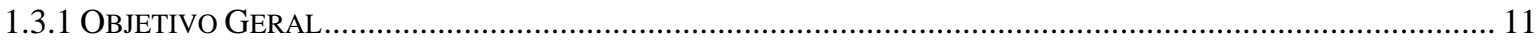

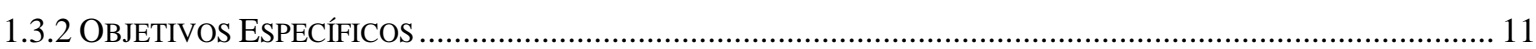

1.4 JUSTIFICATIVA............................................................................................................................................. 12

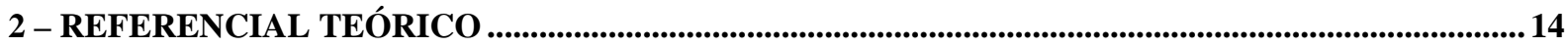

2.1 AS MUDANÇAS NOS AMBIENTE INTERNO E EXTERNO DA ORGANIZAÇÃO.............................14

2.2 ESTRATÉGIA NAS ORGANIZAÇÕES ........................................................................................... 18

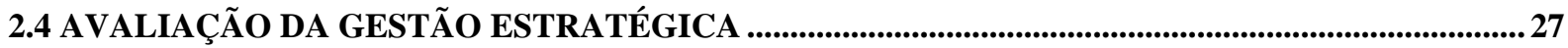

3 - METODOLOGIA DA PESQUISA .................................................................................................................. 31

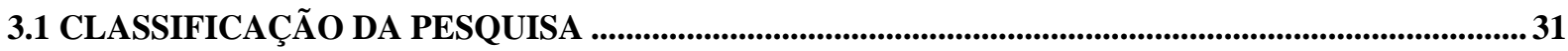

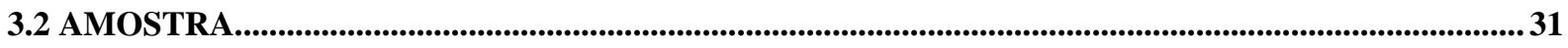

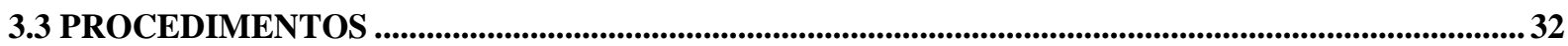

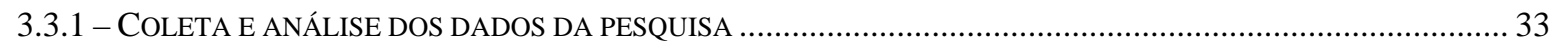

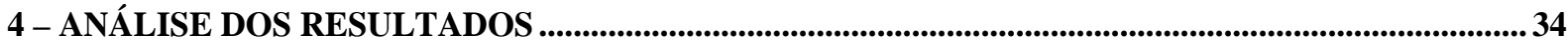

4.1 - ANÁLISE DAS METAS E RESULTADOS RELATIVOS À PERSPECTIVA 1 - SOCIEDADE...... 40

4.1.1 - OBJETIVO ESTRATÉGICO: OFERECER SERVIÇOS SOM QUALIDADE ......................................................... 40

4.1.2 - OBJETIVO ESTRATÉGICO: AMPLIAR A RESPONSABILIDADE SÓCIO-AMBIENTAL ……................................... 44

4.2 - ANÁLISE DAS METAS E RESULTADOS RELATIVOS À PERSPECTIVA 2 - PROCESSOS

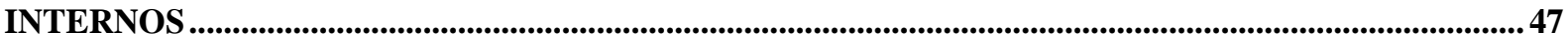

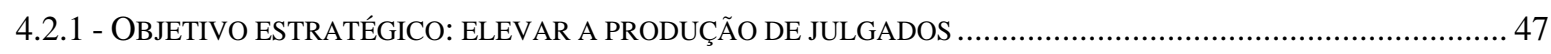

4.2.2 - OBJETIVO ESTRATÉGICO: ACELERAR O TRÂMITE PROCESSUAL ........................................................... 51

4.2.3 - OBJETIVO ESTRATÉGICO: MANTER EM PATAMARES ELEVADOS O CONCEITO DO TRIBUNAL PERANTE A

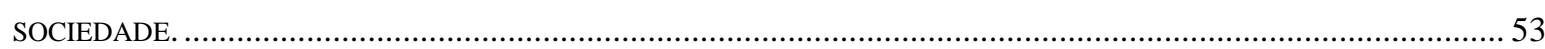

4.3 - ANÁLISE DAS METAS E RESULTADOS RELATIVOS À PERSPECTIVA 3 - APRENDIZADO E

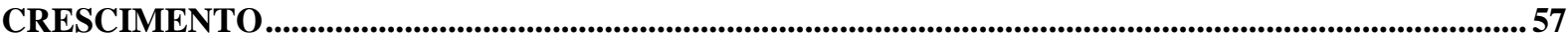

4.3.1 - OBJETIVO ESTRATÉGICO: CONTRIBUIR PARA MODERNIZAÇÃO DO JUDICIÁRIO ......................................... 57

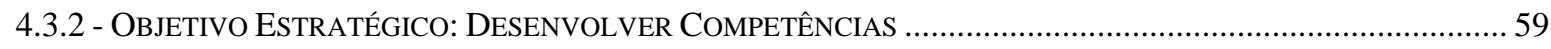

4.3.3 - OBJETIVO ESTRATÉGICO: MELHORAR O CLIMA ORGANIZACIONAL …………………………………….... 62

4.4 - ANÁLISE DAS METAS E RESULTADOS RELATIVOS À PERSPECTIVA 4 - ORÇAMENTO.. 64 


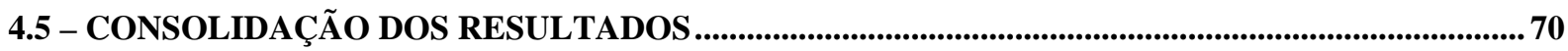

4.6 - ANÁLISE DO DESEMPENHO ................................................................................................................... 74

5 - CONCLUSÃO

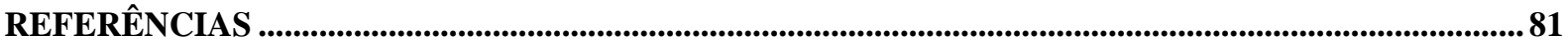

ANEXo A- MAPA ESTRATÉGICO do PLANO DE GESTÃo 2004-2006 ………………………………….......... 85

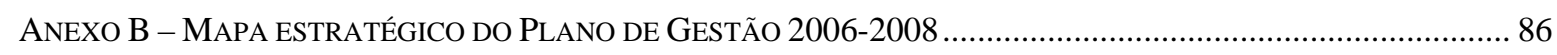

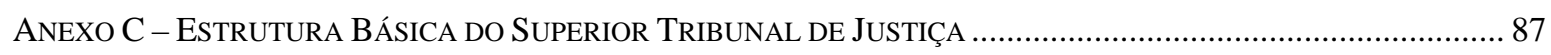




\section{1 - Introdução}

A demanda pela prestação jurisdicional no Brasil vem crescendo de forma visível nas duas últimas décadas exigindo dos órgãos do poder judiciário, que por suas tradições e costumes mostravam-se como organizações fechadas e resistentes a mudanças, adaptações para lidar com as novas necessidades da sociedade cada vez mais consciente de seus direitos e cada vez mais exigente.

Em resposta a necessidade provocada pela grande mudança nos ambientes externo e interno, o Superior Tribunal de Justiça (STJ) tem adotando, desde 2004, uma política alinhada com conceitos de gestão estratégica (Plano de Gestão 2004 - 2006). As mudanças externas, constantes e de grande amplitude, acabam exigindo que o órgão se envolva em processos internos de mudança. Essas mudanças, dependendo do seu vulto, poderão exigir mudanças organizacionais e/ou culturais.

Segundo Oliveira (2004, p. 59), “um cenário que vem apresentando constante mutação ambiental e organizacional, a administração deve ser sistematicamente repensada, para quebrar os paradigmas e consolidar novos modelos de gestão”. Segundo o autor, essas mudanças têm dois pressupostos básicos: A mudança evolutiva do pensamento administrativo - e estratégico - dos executivos e profissionais das organizações; e o desenvolvimento de metodologias e técnicas administrativas - inerentes ao processo de planejamento estratégico que proporcionem sustentação a esse processo de mudança evolutiva.

Portanto, o entendimento das questões relacionadas com processos de mudança é de grande importância para a implantação e o desenvolvimento da Administração Estratégica nas organizações para que apresentem respostas efetivas e coordenadas aos desafios que surgem.

Para Chiavenato e Sapiro (2003), a implementação de um sistema de planejamento estratégico no âmbito das organizações é vista na atualidade como fator fundamental para a sua inserção no ambiente em que atua, contribuindo, inclusive, para viabilizar a sua continuidade ao longo do tempo.

Esse sistema de planejamento faz com que a organização caminhe na direção de sua visão de negócios, missão e objetivos globais. Isso passa pela formulação do plano estratégico e pela implementação dos projetos e ações dele decorrentes. Entretanto, é imprescindível avaliar se a organização caminha no rumo definido. Essa tarefa não pode ser realizada apenas 
pelos instrumentos tradicionais de medição dos acontecimentos passados, mas acrescentandose a aferição dos investimentos nas capacidades que produzirão valor futuro.

Consta no Plano de Gestão 2004 - 2006 que a ferramenta utilizada pelo STJ para auxiliar nessa medição é o Balanced Scorecard. Criado em 1992 por Robert Kaplan e David Norton (1997), da Harvard Business School, o Balanced Scorecard veio preencher, segundo os autores, a lacuna existente na maioria dos sistemas gerenciais da atualidade, que era a falta de um processo sistemático para a obtenção de feedback sobre a estratégia.

Este trabalho se insere no contexto do planejamento estratégico, mais especificamente no modelo de gestão estratégica adotado pelo STJ no período 2004 - 2008, abordando primeiramente a revisão da literatura, de modo a apresentar ao leitor conceitos que permitam compreender a implantação e a gestão do modelo. A partir desse embasamento teórico, pretende-se analisar o processo de implantação da gestão estratégica no STJ, no período de 2004 a 2008, identificando objetivos, metas, projetos e ações definidas, bem como os resultados alcançados e as causas dos eventuais desvios em relação à estratégia da organização.

No primeiro tópico, além da apresentação do STJ, será abordado o problema, os objetivos gerais e específicos, bem como a justificativa para desenvolver a pesquisa. Em seguida, no segundo tópico, será apresentada a revisão bibliográfica sobre o tema escolhido, procurando abordar diversos conceitos e teorias necessárias à melhor compreensão do assunto. No terceiro tópico serão abordadas as questões metodológicas, com detalhamento da pesquisa documental empregada. Finalmente, nos quarto e quinto tópicos são apresentadas as análises dos resultados e as conclusões, respectivamente.

\subsection{Contexto da Pesquisa}

O presente estudo trata de uma pesquisa documental realizada no Superior Tribunal de Justiça - STJ, órgão do Poder Judiciário que foi instituído pelo art.104 da Constituição de 1988, e instalado em 7 de abril de 1989 (Lei n. ${ }^{\circ}$ 7.746/89).

A visão definida para o STJ no Plano de Gestão do biênio 2006/2008 é “ser reconhecido pela sociedade como modelo na garantia de uma justiça acessível, rápida e efetiva” e sua missão é "Processar e julgar as matérias de sua competência originária e recursal, assegurando uniformidade na interpretação das normas infraconstitucionais e oferecendo ao jurisdicionado uma prestação acessível, rápida e efetiva”. 
Em 2004, foi incorporada ao processo de planejamento do STJ a elaboração de planos estratégicos. Esse processo de planejamento é coordenado pela área de gestão estratégica, ligada à secretaria do tribunal (Estrutura básica do STJ - anexo C).

Os planos de gestão apresentados nos biênios 2004/2006 e 2006/2008 consolidam projetos e ações que traduzem os esforços que estão sendo realizados a fim de garantir o atendimento das metas e dos objetivos considerados estratégicos para o Superior Tribunal de Justiça.

O STJ utiliza o sistema Balanced Scorecard como instrumento de gestão desde 2004. O plano de gestão 2006 - 2008 foi organizado nas quatro perspectivas definidas no modelo. A perspectiva cliente é denominada sociedade e a financeira é chamada orçamento. Para as outras duas perspectivas são empregadas a nomenclatura do modelo: processos internos e aprendizado e crescimento.

\subsection{Formulação do problema de pesquisa}

Nos últimos anos, o STJ passou a adotar a gestão do planejamento estratégico como fator essencial no cumprimento de suas funções institucionais. Essa iniciativa foi desenvolvida com a participação dos diversos níveis da organização. Dada a importância do assunto, identifica-se o seguinte problema: quais os resultados alcançados na implementação da gestão estratégica no Superior Tribunal de Justiça?

\subsection{Objetivos}

Buscando-se responder ao problema de pesquisa, foram delineados os seguintes objetivos:

\subsubsection{Objetivo Geral}

Identificar os objetivos e metas estipulados no processo de gestão estratégica do STJ, relativos aos biênios 2004/2006 e 2006/2008, e comparar os resultados alcançados com as metas fixadas, de modo a verificar se o plano estratégico do Tribunal está sendo observado na prática.

\subsubsection{Objetivos Específicos}

Para que o trabalho alcance plenamente o objetivo proposto, faz-se necessário o 
cumprimento dos propósitos a seguir elencados:

a) Pesquisar a literatura sobre o tema do trabalho, procurando abordar os diversos conceitos e teorias necessárias à melhor compreensão do assunto;

b) Identificar os objetivos e as metas definidas no planejamento estratégico do STJ, durante o período objeto da análise;

c) Identificar os resultados alcançados;

d) Identificar os desvios em relação aos objetivos e metas programadas e elencar as possíveis causas;

\subsection{Justificativa}

É visível a preocupação da alta administração com a Instituição e com seus objetivos estratégicos. No planejamento estratégico do STJ vê-se “intenções” voltadas para a correção das anomalias internas.

Um dos pontos que devem merecer maior atenção no processo de planejamento estratégico do STJ é a forma de lidar com a mudança nos seus ambientes internos e externos. No que se refere ao cenário interno, destaca-se a complexidade da cultura organizacional no STJ, sendo esse um fator determinante para que as estratégias delineadas tenham sucesso. Logo, é preciso encontrar meios adequados para lidar com esse fator.

Freitas (2007, p. 67) considera que "para os indivíduos, uma vez que tenham assimilado a cultura de uma organização tendem a manter o comportamento aprendido”. Toda mudança organizacional tende a sofrer resistências em razão do medo provocado pelo novo. Em situações antigas para as quais há soluções conhecidas, mesmo que estas não sejam as melhores, dificilmente buscar-se-ão outras soluções diversas.

A este respeito Leitão (1995, p. 233) destaca que “a grande turbulência que se verifica, cada vez mais, no ambiente interno e externo às organizações tem exigido uma competência profissional cada vez mais especializada, além de persistência e crença nas idéias que se está defendendo". Sendo por isso necessário adotar conceitos estratégicos que permitam as organizações trabalhar de forma a saber a hora certa de agir. Para o mesmo autor, a Gestão Estratégica vem auxiliar por ser um processo estruturado e organizado para administrar o futuro da organização, em função das possíveis evoluções dos ambientes externo e interno. Deve ainda procurar identificar a melhor estratégia, isto é, o melhor caminho, a fim de 
direcionar a organização para o futuro.

Por outro lado, a cultura organizacional sofre influência e deve responder adequadamente aos anseios de uma sociedade em constante evolução, cada vez mais exigente no que diz respeito ao papel das organizações. Sendo assim, há que se levar em consideração esse ambiente externo em permanente mudança.

Esta problemática é analisada por Silveira e Vivacqua (1999. p. 21), quando afirma que:

A mudança organizacional, ao contrário de ser rotineira e previsível, é instável, acelerada e, até certo ponto, revolucionária. Na situação atual as revoluções estão testando continuamente a capacidade de adaptação das organizações às novas circunstâncias e, fundamentalmente, impondo a necessidade de utilização de novas tecnologias que visem à inovação das organizações num ambiente em turbulência.

O planejamento estratégico constituiria, segundo os autores, uma das mais importantes ferramentas de mudança, convertendo-se em parte relevante da responsabilidade da administração de todas as organizações contemporâneas, independente de suas finalidades. As mudanças ocorrem continuamente e as organizações devem enfrentar desafios à transformação e ao ajustamento às novas situações ambientais.

Isso pode ser retratado nas palavras de Silveira e Vivacqua (1999, p.21), quando enfatiza que:

\begin{abstract}
O processo inovador vem reclamando cada vez mais respostas rápidas às situações presentes que devam ser operadas por saltos de um estado a outro. É um permanente processo em que há sempre um passado e um futuro a considerar - contradições do antigo e do novo, buscando sempre novas sínteses organizacionais. Como conseqüência, as organizações devem dispor, de forma contínua, de sistemas de informações para decisões, cujo objetivo é ajustá-las a um mundo em que as forças dinâmicas da ciência e da tecnologia, entre outras, exijam orientação para a mudança. Dessa perspectiva, as organizações têm que orientar suas decisões para respostas internas e imediatas à revisão de seus planos, além de respostas externas que atendam, em tempo hábil, as necessidades das demandas do meio ambiente.
\end{abstract}

É imprescindível, portanto, avaliar a forma como a gestão estratégica do STJ vem lidando com essa questão, bem como o grau de efetividade do próprio processo de planejamento, traduzida aqui em termos de resultados alcançados comparativamente aos objetivos propostos e à própria capacidade de redefinir as prioridades em resposta aos cenários externo e interno.

Já que o processo de planejamento estratégico mostra-se como uma ferramenta básica da gestão, é importante efetuar uma análise qualitativa de sua eficácia ao longo dos últimos anos. 


\section{2 - Referencial Teórico}

Pretende-se explorar no estudo uma vasta literatura sobre as questões relacionadas ao planejamento estratégico, não apenas no que diz respeito ao impacto das mudanças nos ambientes interno e externo, mas também no que se refere ao modelo de planejamento e gestão estratégica que vem sendo utilizado pelo STJ.

\subsection{As mudanças nos ambiente interno e externo da organização}

Segundo Morgan (1976 apud Silveira e Vivacqua, 1999 p. 19), “as organizações fazem, em média, uma grande reestruturação de dois em dois anos”. Mas por que se muda tanto? A resposta a esta pergunta é de fácil dedução: porque as mudanças geralmente são impostas, a decisão parte da alta direção.

Para Senge at al. (2000), a palavra mudança tem sido usada nas organizações com vários significados, os quais, em muitos casos, são contraditórios. Às vezes ela é usada com referência a mudanças externas em tecnologia, no comportamento dos clientes, na concorrência, na estrutura de mercado ou no ambiente sociopolítico. Outras vezes como mudanças internas, visando adaptar-se a mudanças no meio ambiente. A eterna preocupação é se essas mudanças internas - nas práticas, visões e estratégias - manterão seu compasso com as mudanças externas.

Freitas (2007 p. 55) afirma: “A questão da mudança é crucial na discussão estratégica”. Hoje, o termo mudança também pode significar programas de cima para baixo como reorganização, reengenharia e muitos outros "re-alguma coisa". Visto que esses programas de mudança são tipicamente impostos de cima para baixo, muitas pessoas na organização se sentem ameaçadas ou manipuladas por eles - mesmo se, em princípio, elas apóiem a intenção ou o raciocínio subjacente à agenda de mudanças. Caso houvesse o equilíbrio entre a cultura organizacional e as mudanças estratégicas necessárias, mantendo-se um clima flexível, haveria maior facilidade para as transformações.

O autor Kotter (1997) estudando o mesmo assunto, conclui que a quantidade de mudança revolucionária e freqüentemente traumática nas organizações tem crescido substancialmente ao longo das duas últimas décadas. Embora algumas pessoas acreditem que a maioria dos projetos de reengenharia, de mudanças de estratégia, de fusões, de qualidade e de renovação cultural irão desaparecer em breve, o autor defende que as mudanças vão 
continuar. Acredita que cada vez mais organizações serão levadas a reduzir os custos, melhorar a qualidade de produtos e serviços, estabelecer novas oportunidades de crescimento e aumentar a produtividade para manterem-se vivas e atuantes.

Kotter (1997), analisando um estudo de cem organizações que empreenderam esforços de "transformação empresarial” conduzidos pela alta administração, concluiu que mais da metade não sobreviveu às fases iniciais. Ele encontrou algumas empresas que tinham sido “muito bem-sucedidas” e outras que foram "verdadeiros fracassos”. A maioria registrava tendência ao fracasso.

De acordo com a literatura consultada, os principais esforços de mudança organizacional ajudaram algumas organizações a se adaptarem de forma significativa às condições de transformação, aprimoraram a posição competitiva de outras e prepararam algumas para um futuro melhor. Em muitas situações, porém, as melhorias foram decepcionantes e o quadro final desanimador, com recursos desperdiçados e funcionários dispensados, apreensivos ou frustrados. De qualquer forma, o preço da mudança é inevitável, e para (Freitas 2007 p. 65) "não se discute mais se uma mudança organizacional é ou não possível, mas basicamente como fazê-la de forma a se reduzir os prejuízos que a desorientação coletiva pode causar dentro da organização”.

Sobre o tema em discussão o autor Senge at al. (2000, p. 16) tem opinião semelhante à Kotter (1997) afirmando: “a maioria das iniciativas de mudança fracassa”. Para subsidiar a afirmativa analisou dois estudos independentes realizados no início dos anos noventa, um publicado pela Arthur D. Litle e outro pela Mckinsey \& Co. Descobriram que, de centenas de programas corporativos de Gestão da Qualidade Total estudados, cerca de dois terços “acabam sendo suspensos porque deixam de produzir os resultados esperados”. A reengenharia não teve melhor êxito; inúmeros artigos, inclusive de alguns dos fundadores da reengenharia, apontaram para um índice de fracasso de aproximadamente setenta por cento.

Senge at al. (2000) também afirma que mesmo sem conhecer as estatísticas, quase todos sabem que programas de mudança fracassam. Já se viu muito "programa do mês" ser anunciado pela administração e depois ficar uma vida inteira sem surtir efeito, gerando descrença na organização. Tantas vezes a administração anuncia um "brinde ao novo programa” e, em seguida, comenta-se baixinho “E lá vamos nós, de novo...” e “Isto não vai funcionar nunca!”. Algumas organizações até criam seu próprio jargão para rir um pouco de seu ceticismo. 
Analisando a opinião dos autores fica evidente que as organizações não têm um histórico bom no que diz respeito à sustentação de mudanças organizacionais significativas. E há pouca evidência de que instituições governamentais e sem fins lucrativos apresentem melhores resultados.

Diante do cenário de mudança traçado será conveniente levar-se em conta que a sustentação de qualquer processo de mudança profunda requer uma mudança fundamental na maneira de pensar. Precisa-se compreender a natureza dos processos de crescimento e saber como catalisá-los. Mas também se têm que compreender as forças e os desafios que impedem o progresso, e tem-se que desenvolver estratégias viáveis para lidar com estes desafios. Isto requer tanto paciência quanto urgência. Requer um verdadeiro espírito de investigação, uma genuína curiosidade sobre as forças restritoras, requer que se veja como uma mudança significativa invariavelmente começa localmente, pequena, e como ela cresce ao longo do tempo. E requer que se reconheça a gama diversificada de pessoas que desempenham papéischave na sustentação da mudança - pessoas que são “líderes”.

Senge et al. (2000, p. 40 - 41) identificou desafios - forças que se opõe à mudança profunda, que de certa forma limitam a implantação da mudança em todas as fases (início, sustentação e no momento de repensá-las). São eles:

Desafios ao iniciar as mudanças:

- Controlar o próprio tempo - pessoas envolvidas com a iniciativa de mudança precisam ter flexibilidade para dedicarem tempo à reflexão e prática;

- O tutoriamento - orientação e apoio inadequados para grupos inovadores e o desafio de acabar tendo que desenvolver recursos internos para construir capacidade;

- A relevância - provar que a mudança é necessária;

- A clareza e coerência gerencial - o descompasso entre o comportamento e os valores proclamados, especialmente para aqueles que defendem as mudanças.

Desafios após o impulso inicial, ou seja, quando algum progresso já fora alcançado, na fase de sustentação das mudanças:

- O medo e a ansiedade - preocupações com exposição, vulnerabilidade e inadequação, provocada pelo conflito entre níveis cada vez maiores de compreensão mútua e abertura e baixos níveis de confiança entre os membros do grupo; 
- Avaliação negativa do progresso - a desconexão entre as formas tradicionais de a organização medir o sucesso e as advindas da mudança;

- O isolamento e a arrogância - o grupo responsável pela mudança e o resto da organização estão sempre interpretando mal uns aos outros;

Desafios na hora de repensar as mudanças, quando elas já ganharam maior credibilidade e confrontam com a infra-estrutura e as práticas organizacionais estabelecidas:

• “Quem é responsável por esta coisa?” - conflitos entre o grupo responsável pelas mudanças e os gerentes preocupados que a autonomia leve ao caso e à reestruturação interna;

- “Estamos sempre reinventado a roda!” - a incapacidade de transferir conhecimento além das fronteiras da organização, dificultando o desenvolvimento das pessoas;

- O desafio da estratégia e do propósito da organização - revitalizar e repensar o foco pretendido para a organização.

Cada organização se deparará com desafios em sua própria seqüência, não necessariamente na ordem em que o autor apresentou os dez desafios. No entanto, para líderes que buscam iniciar, sustentar ou repensar a mudança, é importante compreender estas limitações e saber superá-las.

Para Leitão (1995) normalmente os gerentes vêem o processo de mudança de forma parcial, sob um enfoque tático. Assim, mais comumente, alguns efetuam um processo de mudança, adotando apenas uma nova estrutura organizacional para a empresa. Entretanto, uma mudança organizacional efetiva exige envolvimento da parte técnica, política e cultural da organização. A gerência do processo de mudança significa a administração das tarefas de modo a permitir a passagem de um estado de equilíbrio até outro estado desejado ou definido pelas estratégias. Esta passagem se dá por meio de um estado intermediário de transição, durante o qual ocorre a mudança.

Para o autor esse processo requer atenção e acompanhamento constante, de forma que a mudança estratégica mantenha a organização alinhada interna e externamente. 


\subsection{Estratégia nas organizações}

Segundo Chiavenato e Sapiro (2003) o conceito de estratégia não é recente. Ele existe desde quando o homem das cavernas se pôs a caçar, pescar ou lutar para poder sobreviver. A estratégia sempre esteve presente como um plano antecipado do que fazer para ser bemsucedido.

Leitão (1995) fez um breve histórico do termo “estratégia” discorrendo que a palavra é de origem grega strátegos e inicialmente referia-se a uma posição (o general no comando de um exército), e que mais tarde veio a designar "a arte do general”, significando a aplicação das competências do general no exercício de sua função (arte militar). Já Silveira e Vivacqua (1999, p. 34) afirma que “em administração, a abordagem estratégica só por analogia pode ser comparada com uma campanha militar”. Para os autores a melhor compreensão do termo estratégia seria um redirecionamento da organização para uma mudança no futuro, influenciando os ambientes interno e externo.

Leitão (1995, p. 57) listou algumas definições clássicas de “estratégia”, apresentando uma coletânea dos mais importantes estudiosos do assunto. Para o autor, tais definições ajudam a esclarecer a evolução do conceito e de suas diversas interpretações. As principais definições apresentadas são as seguintes:

“Estratégia é uma série de ações tomadas por uma empresa e definidas de acordo com uma situação particular”. (Von Neumann e Morgenstern (1947)).

"Estratégia é a análise da situação presente e a sua mudança se necessário. Incorporada na estratégia está a definição dos recursos atuais e os necessários.” (Peter Drucker (1954)).

“Estratégia é o determinante das metas básicas de longo prazo de uma empresa e a adoção dos cursos de ação e alocação de recursos necessários para atingir essas metas” (Chandler (1962)).

"Estratégia é a regra para tomar decisões determinadas pelo escopo produto/mercado, vetor de crescimento, vantagem competitiva e sinergia.” (Ansoff (1965)).

“Estratégias são decisões diretivas de ações requeridas para, competitivamente, alcançar o propósito da companhia.” (Cannon (1968)).

“Estratégias são planos que antecipam mudanças e iniciam ações para aproveitar oportunidades que estão integradas na Missão da companhia.” (Newman e Logan (1971)).

“A estratégia está preocupada com os objetivos de longo prazo e os meios para alcançá-los 
que afetam o sistema como um todo.” (Ackoff (1974)).

“Estratégia é um plano unificado, abrangente e integrado, elaborado para assegurar que os objetivos da empresa serão alcançados.” (Glueck (1976)).

“Estratégia é o estabelecimento da Missão da companhia, a definição de objetivos para a organização, a luz das forças internas e externas, a formulação de políticas específicas e estratégias para alcançar os objetivos e assegurar sua implementação, de forma que os objetivos básicos e propósitos da organização sejam alcançados.” (Steiner e Miner (1977)).

“Estratégia é a força que interliga a organização e seu ambiente externo, ou seja, padrões consistentes de decisões organizacionais que lidam com o meio ambiente externo.” (Mintzberg (1979)).

“A estratégia provê direcionamentos para a organização que permitam o alcance de seus objetivos, respondendo às ameaças e oportunidades do seu ambiente externo.” (Schendel e Hofer (1979)).

“Estratégia é o padrão de decisões em uma companhia que determina e revela seus objetivos, propósitos ou metas, produz as principais políticas e planos para alcançar essas metas e define o tipo de negócio que a companhia deve perseguir o tipo de organização econômica e humana que ela é ou pretende ser e a natureza da contribuição econômica e não-econômica que ela pretende fazer a seus acionistas, empregados, cliente e comunidades.” (Andrews (1980)).

“Estratégia é um conjunto coerente de ações, cuja finalidade é ganhar uma vantagem sustentável sobre seus competidores, melhorar a sua posição junto aos clientes, permitindo melhor alocação de recursos.” (Peters e Waterman (1982)).

"Estratégia é um curso de ação com vistas a garantir que a organização alcance seus objetivos.” (Certo e Peter (1990)).

Analisando as diversas definições, o autor agrupou os diferentes conceitos em duas correntes de pensamentos: uma que dá ao termo “estratégia” um significado amplo, abrangendo todo o processo, desde a definição dos objetivos até a fixação das ações e recursos, podendo ser usada como sinônimo de Administração Estratégica; e a outra, que dá ao termo um sentido restrito, significando o caminho escolhido para se alcançar os objetivos, o “como fazer”.

Kaplan e Norton (2004, p.34) consideram que a "estratégia não é um processo gerencial isolado; é uma das etapas de um processo contínuo lógico que movimenta toda a 
organização desde a declaração de missão de alto nível até o trabalho executado pelos empregados da linha de frente e de suporte”.

Dada a complexidade de interpretar o termo “estratégia”, Mintzberg (2000, p. 13 - 14) trouxe, entre outras contribuições, a de ter catalogado as escolas “estratégicas”, classificandoas em dez tipos, conforme relacionado abaixo, juntamente com o adjetivo que melhor parece captar a visão que cada uma tem do processo de estratégia, segundo o autor:

A Escola do Design: $\quad$ formulação de estratégia como um processo de concepção.

A Escola do Planejamento: formulação de estratégia como um processo formal A Escola do Posicionamento: formulação de estratégia como um processo analítico A Escola Empreendedora: formulação de estratégia como um processo visionário A Escola Cognitiva: formulação de estratégia como um processo mental A Escola de Aprendizado: formulação de estratégia como um processo emergente A Escola do Poder: formulação de estratégia como um processo de negociação A Escola Cultural: $\quad$ formulação de estratégia como um processo coletivo A Escola Ambiental: $\quad$ formulação de estratégia como um processo reativo A Escola de Configuração: formulação de estratégia como um processo de transformação.

O autor considera que as escolas surgiram em estágios diferentes do desenvolvimento da administração estratégica. Para ele algumas já chegaram ao pico e declinaram, outras estão agora se desenvolvendo e outras permanecem pequenas, mas significativas.

Conforme Mintzberg (2000) hoje os gerentes usam o termo estratégia livre e afetuosamente, sendo considerada o ponto alto da atividade dos executivos. Já os acadêmicos vêm estudando amplamente a estratégia há duas décadas, ao passo que as escolas de Administração geralmente têm como clímax um curso de administração estratégica. Logo, a palavra estratégia é muito influente, tem vários conceitos e chega-se ao questionamento do significado real da palavra. Reconhecendo várias definições para o termo estratégia, o autor faz um resumo das áreas gerais de concordância a respeito da natureza da estratégia, conforme indicado no quadro da página seguinte.. 
- $\quad$ A estratégia diz respeito tanto à organização como ao ambiente. "Uma premissa básica para se pensar a respeito de estratégia diz respeito à impossibilidade de separar organização e ambiente... A organização usa a estratégia para lidar com as mudanças nos ambientes."

- A essência da estratégia é complexa. "Como as mudanças trazem novas combinações de circunstâncias para a organização, a essência da estratégia permanece não-estruturada, não-programada, não-rotineira e nãorepetitiva...”

- A estratégia afeta o bem-estar geral da organização. “... decisões estratégicas... são consideradas importantes o suficiente para afetar o bem-estar geral da organização...”

- A estratégia envolve questões tanto de conteúdo como de processo. "O estudo da estratégia inclui as ações decididas, ou o conceito de estratégia, e também os processos pelos quais as ações são decididas e implementadas.”

- As estratégias não são puramente deliberadas. "Os teóricos... concordam que as estratégias pretendidas, emergentes e realizadas podem diferir entre si”.

- As estratégias existem em níveis diferentes. “....as empresas têm... estratégia corporativa (“em que negócio deveremos estar?”) e estratégia de negócio (“como iremos competir em cada negócio?”)”

- A estratégia envolve vários processos de pensamento. “... a estratégia envolve exercícios conceituais, assim como analíticos. Alguns autores enfatizam a dimensão analítica mais que as outras, mas a maioria afirma que o coração da formulação de estratégias é o trabalho conceitual feito pelos líderes da organização”.

Quadro 1 - O animal da estratégia: áreas de concordância (adaptado de Chaffee, 1985: 89-90)

Fonte Mintzberg (2000, p. 21)

De acordo com a ponderação de Mintzberg (2000) qualquer discussão sobre estratégia evolui inevitavelmente para vários questionamentos. Ele comenta que para cada vantagem associada à estratégia, há uma desvantagem correspondente, conforme indicado no quadro a seguir.

\begin{tabular}{|c|c|c|}
\hline Afirmativa & Vantagem & Desvantagem \\
\hline $\begin{array}{l}\text { A estratégia fixa } \\
\text { a direção. }\end{array}$ & $\begin{array}{l}\text { O principal papel da estratégia é } \\
\text { mapear o curso de uma organização } \\
\text { para que ela navegue coesa através } \\
\text { do seu ambiente. }\end{array}$ & $\begin{array}{l}\text { A direção estratégica também pode constituir um conjunto } \\
\text { de antolhos para ocultar perigos em potencial. Seguir um } \\
\text { curso predeterminado em águas desconhecidas é a maneira } \\
\text { perfeita para colidir com um iceberg. }\end{array}$ \\
\hline $\begin{array}{l}\text { A estratégia } \\
\text { focaliza o } \\
\text { esforço. }\end{array}$ & $\begin{array}{l}\text { A estratégia promove a } \\
\text { coordenação das atividades. Sem a } \\
\text { estratégia para focalizar os } \\
\text { esforços, as pessoas puxam em } \\
\text { direções diferentes e sobrevém o } \\
\text { caos. }\end{array}$ & $\begin{array}{l}\text { O “pensamento grupal” surge quando o esforço é } \\
\text { excessivamente focalizado. Pode não haver visão } \\
\text { periférica para abrir outras possibilidades. Uma } \\
\text { determinada estratégia pode tornar-se demasiado embutida } \\
\text { no tecido da organização. }\end{array}$ \\
\hline $\begin{array}{l}\text { A estratégia } \\
\text { provê } \\
\text { consistência. }\end{array}$ & $\begin{array}{l}\text { A estratégia é necessária para } \\
\text { reduzir a ambigüidade e prover } \\
\text { ordem. Nesse sentido, uma } \\
\text { estratégia é como uma teoria: uma } \\
\text { estrutura cognitiva para simplificar } \\
\text { e explicar o mundo e com isso } \\
\text { facilitar a ação. }\end{array}$ & $\begin{array}{l}\text { É preciso compreender que toda estratégia, como toda } \\
\text { teoria, é uma simplificação que necessariamente distorce a } \\
\text { realidade. Estratégias e teorias não são realidades; apenas } \\
\text { representações (ou abstrações) da realidade nas mentes das } \\
\text { pessoas. Ninguém jamais tocou ou viu uma estratégia. Isso } \\
\text { significa que cada estratégia pode ter um efeito de } \\
\text { informação falsa ou distorção. Esse é o preço de se ter uma } \\
\text { estratégia. }\end{array}$ \\
\hline
\end{tabular}




\begin{tabular}{|l|l|l|}
\hline $\begin{array}{l}\text { A estratégia } \\
\text { define a }\end{array}$ & $\begin{array}{l}\text { A estratégia propicia às pessoas } \\
\text { uma forma taquigráfica para }\end{array}$ & $\begin{array}{l}\text { Definir a organização com excesso de exatidão também } \\
\text { pode significar defini-la com excesso de simplicidade, às } \\
\text { vezes até o ponto de estereotipá-la, perdendo-se assim a }\end{array}$ \\
& $\begin{array}{l}\text { entender sua organização e } \\
\text { distingui-la das outras. A estratégia } \\
\text { provê significado, além de uma } \\
\text { forma conveniente para se entender } \\
\text { o que faz a organização. }\end{array}$ & \\
\hline
\end{tabular}

Quadro 2 - Vantagens e Desvantagens associadas à estratégia.

Fonte Mintzberg (2000, p. 22)

Mintzberg (2000) chama atenção para o fato de que funciona-se melhor quando podese conceber algumas coisas como certas, ao menos por algum tempo. E este é um papel importante da estratégia nas organizações: ela resolve as grandes questões para que as pessoas possam cuidar dos pequenos detalhes - como voltar-se para os clientes e atendê-los, ao invés de debater quais mercados são os melhores.

Existe uma tendência de descrever o executivo principal como um estrategista, que fica lá no alto concebendo as grandes idéias, enquanto todos os outros cuidam dos pequenos detalhes. Segundo Mintzberg (2000), não é bem assim, pois, a maior parte do trabalho desenvolvido pelo alto executivo tem a ver com seus próprios pequenos detalhes - reforçar a perspectiva existente (e a “cultura”) através de todos os tipos de deveres que competem a uma pessoa nesta posição-chave, desenvolver contatos para descobrir informações importantes, negociar acordos para reforçar as posições existentes e assim por diante.

O autor conclui que o problema está nas situações que acabam mudando - ambientes se desestabilizam, nichos desaparecem, oportunidades se abrem. Então, tudo aquilo que é construtivo e eficaz a respeito de uma estratégia estabelecida passa a ser uma desvantagem. É por isso que, apesar de o conceito de estratégia estar baseado em estabilidade, grande parte do estudo de estratégia focaliza mudanças. Mas embora as fórmulas para mudanças estratégicas possam sair facilmente, o gerenciamento das mesmas, em especial quando envolvem mudanças de perspectiva, é difícil. O próprio encorajamento da estratégia para lidar com mudanças influencia a capacidade dos indivíduos para reagir às alterações no ambiente. Em outras palavras, mudar as ferramentas é dispendioso, em especial por se tratar de pessoas e não máquinas que precisam ser reprogramadas. A estratégia, como estado mental, pode cegar a organização, levando-a a própria obsolescência. Assim, conclui o autor, as estratégias (e o processo de administração estratégica) podem ser vitais para as organizações tanto por sua ausência quanto por sua presença. 
Kaplan e Norton (2004, p. 6) analisam o alto índice de estratégias fracassadas concluindo que: "Na maioria dos casos o verdadeiro problema não é \{má estratégica\}.... é má execução. Sem dúvida, a maioria das empresas não é bem-sucedida na implementação da estratégia”. Os autores criadores do Balanced Scorecard fazem uma ressalva: “Em contraste com essa marca sombria, as empresas que adotaram o Balanced Scorecard como pedra fundamental de seus sistemas gerenciais, superaram essa tendência negativa. Implementaram novas estratégias com eficácia e rapidez”. 


\subsection{0 planejamento estratégico}

Segundo Leal Filho (2005, p. 83) “o aparecimento do planejamento estratégico representou uma contribuição inovadora no campo da gestão e do processo decisório das organizações, por ter revelado a ligação entre a organização e o ambiente”.

Para Kunsch (2006, p. 129) “quando se utiliza o planejamento estratégico é possível saber a real situação da organização”. Afirma a pesquisadora que na elaboração do planejamento estratégico é necessário fazer uma análise ambiental externa e interna, chegando-se a um diagnóstico organizacional capaz de indicar as ameaças e as oportunidades, os pontos fracos e os pontos fortes, ou seja, traçar um perfil da organização no contexto econômico, político e social. A partir do mapeamento desse estudo do ambiente é que uma organização poderá avaliar a situação e definir sua missão e visão de futuro, rever seus valores corporativos, redefinir o negócio, elaborar filosofias e políticas, traçar objetivos, formular estratégias, metas e projetos estratégicos, elaborar o orçamento e implantar as ações.

Na concepção de Chiavenato e Sapiro (2003, p. 39) o planejamento estratégico "é um processo de formulação de estratégias organizacionais no qual se busca a inserção da organização e de sua missão no ambiente em que ela está atuando”. Chiavenato e Sapiro (2003, p.39, apud DRUCKER. 1984 p.133), “planejamento estratégico é o processo contínuo de, sistematicamente e com o maior conhecimento possível do futuro contido, tomar decisões atuais que envolvem riscos”. Completa ainda que o planejar estrategicamente é “organizar sistematicamente as atividades necessárias à execução dessas decisões e, através de uma retroalimentação organizada e sistemática, medir o resultado dessas decisões em confronto com as expectativas alimentadas”.

Leal Filho (2005, p. 84) analisando o assunto "vê o planejamento estratégico com foco, análise e atuação, na organização como um todo, sob uma perspectiva que busca integrar as várias partes envolvidas no processo”. É um instrumento que adota uma postura proativa, preparando a organização para o amanhã, sem, contudo, abrir mão de sua cultura. Procura antecipar mudanças e problemas, propondo estratégias para solucioná-los.

Oliveira (2004) considera que quando a organização vai implantar o planejamento precisa respeitar alguns princípios gerais e específicos para que os resultados da operacionalização do planejamento seja o esperado. O autor aponta quatro princípios gerais do planejamento, quais sejam: o da contribuição aos objetivos, o da precedência, o da maior penetração e abrangência e o da maior eficiência, eficácia e efetividade. Como princípios 
específicos ele apresenta os do planejamento: participativo, coordenado, integrado e permanente. Enfatiza a importância de o executivo estar atento aos princípios gerais e específicos.

Chiavenato e Sapiro (2003, p.39) quando faz a relação entre o planejamento estratégico e os objetivos estratégicos de médio e longo prazo que afetam a direção ou a viabilidade da organização, considera que o planejamento estratégico “aplicado isoladamente, é insuficiente, pois não se trabalha apenas com ações imediatas e operacionais: é preciso que, no processo de planejamento estratégico, sejam elaborados de maneira integrada e articulada todos os planos táticos e operacionais da organização". O planejamento deve maximizar os resultados e minimizar as deficiências utilizando princípios de maior eficiência, eficácia e efetividade.

Para Oliveira (2004, p.39) "È importante salientar que a eficiência, eficácia e efetividade são algumas das principais medidas para avaliar uma boa administração, pois, normalmente, os recursos com os quais o administrador trabalha são escassos e limitados”. Diante da importância do princípio geral da maior eficiência, eficácia e efetividade o autor elaborou um quadro com o significado dos termos, conforme demonstrado abaixo:

\begin{tabular}{|c|c|c|}
\hline EFICIÊNCIA É & EFICÁCIA É & EFETIVIDADE É \\
\hline $\begin{array}{l}\text { - Fazer as coisas da maneira } \\
\text { adequada }\end{array}$ & - Fazer as coisas certas & - Manter-se sustentável no ambiente \\
\hline - Resolver problemas & $\begin{array}{l}\text { - Produzir alternativas } \\
\text { criativas }\end{array}$ & $\begin{array}{l}\text { - Apresentar resultados globais ao } \\
\text { longo do tempo }\end{array}$ \\
\hline - Cuidar dos recursos aplicados & $\begin{array}{l}\text { - Maximizar a utilização } \\
\text { dos recursos }\end{array}$ & $\begin{array}{l}\text { - Coordenar esforços e energias } \\
\text { sistematicamente }\end{array}$ \\
\hline - Cumprir o dever & - Obter resultados & \\
\hline - Reduzir custos & - Aumentar o lucro & \\
\hline
\end{tabular}

Algumas etapas do planejamento estratégico são tratadas por diversos autores em termos semelhantes, dentre eles Chiavenato e Sapiro (2003), Oliveira (2004) e Leal Filho (2005). Eles consideram que inicialmente existe um acordo entre os tomadores de decisão da organização e as lideranças para iniciar um processo de planejamento estratégico. Ressalta que o apoio e o envolvimento da alta administração são cruciais para as demais etapas do processo e para a continuidade do plano a ser formalizado. Após o acordo inicial vêm as seguintes etapas: a clarificação da missão e dos valores da organização; a visão de futuro; a análise dos cenários externo (ameaças e oportunidades) e interno (pontos fortes e fracos); os fatores-chave de sucesso; a definição dos objetivos; a análise dos públicos de 
interesse; a formulação do plano; e a avaliação do desempenho.

Chiavenato e Sapiro (2003, p. 45) desenvolveu uma metodologia básica para a elaboração e implementação do planejamento estratégico, baseado em cinco partes principais, conforme esquema abaixo. Conclui que a estratégia aponta o caminho e o planejamento estratégico indica como andar nele. O propósito do planejamento estratégico é a formulação do plano estratégico. Após, segue-se a implementação estratégica, que é o processo de construção das ações segundo as quais a organização perseguirá a consecução de sua visão de negócios, missão e objetivos globais. A implementação da estratégia é feita pela execução de planos táticos e operacionais.

PARTE 1

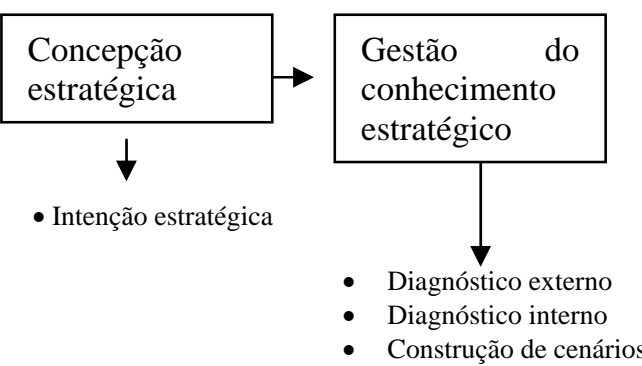

PARTE 3

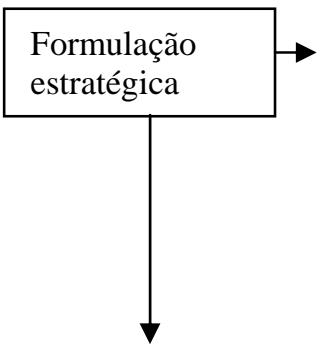

- Planejamento estratégico

- Modelos dinâmicos de

- concorrência
PARTE 4

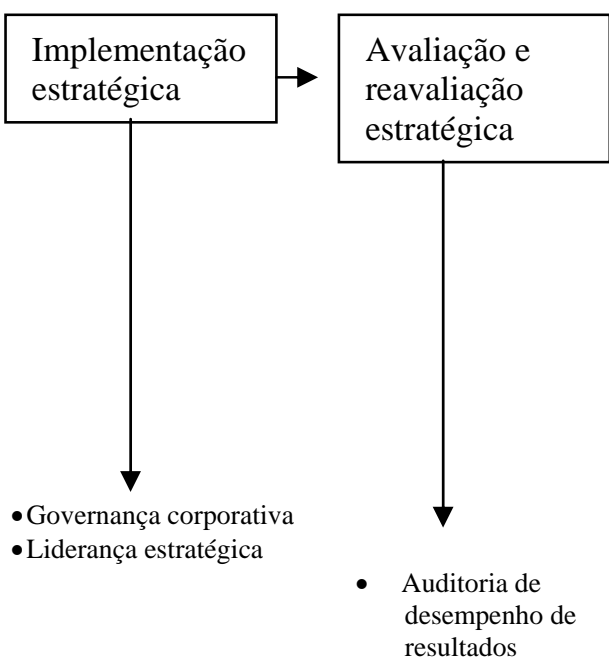

Quadro 4 - Etapas do Planejamento Estratégico.

Fonte: Chiavenato e Sapiro (2003, p. 45).

Oliveira (2004) afirma não haver uma metodologia universal de planejamento estratégico, porque as organizações diferem em tamanho, em tipos de operações, em forma de organização, em filosofia e em estilo administrativo. Portanto, a organização ao elaborar o planejamento estratégico deverá adotar a metodologia que melhor lhe convier, adaptando as condições e realidades internas e externas da organização. 


\subsection{Avaliação da gestão estratégica}

De acordo com a definição de Oliveira (2004) a avaliação da estratégia refere-se à etapa do processo de gestão estratégica na qual a alta administração avalia se a sua escolha estratégica, como foi implementada, está proporcionando o alcance dos objetivos da organização.

Segundo Rezende (2003, p. 78) o Balanced Scorecard (BSC) “atua como um modelo de avaliação, uma sistemática gerencial e uma filosofia de gestão, criando um ambiente balanceado entre medição e mediação à medida que estabelece uma interface entre a estratégia formulada e a agenda estratégica da organização”.

O Balanced Scorecard (BSC) - placar banceado - é um novo sistema de gestão que avalia o desempenho organizacional. Foi proposto em 1992 pelos professores Robert Kaplan e David Norton, da Harvard Business School.

Kaplan e Norton (1997) define o BSC como um modelo que integra as medidas derivadas da estratégia. Sem menosprezar as medidas financeiras do desempenho passado, ele incorpora os indicadores do desempenho financeiro futuro. Esses indicadores abrangem as perspectivas do cliente, dos processos internos e do aprendizado e crescimento, que nascem de um esforço consciente e rigoroso de tradução da estratégia organizacional em objetivos e medidas tangíveis.

Para Kaplan e Norton (1997) é possível desenvolver um Balanced Scorecard inicial com objetivos relativamente restritos: esclarecer, obter consenso e focalizar estratégia, e depois comunicá-la a toda a empresa. Afirmam ainda que (p.20) “o verdadeiro poder do BSC ocorre quando deixa de ser um sistema de medidas e se transforma em um sistema de gestão estratégica”.

Para Kaplan e Norton (1997) um dos objetivos do BSC é o alinhamento do planejamento estratégico com as ações operacionais da organização (quadro abaixo). Segundo os autores esse objetivo é alcançado pelas seguintes ações:

- $\quad$ Esclarecer e traduzir a visão e a estratégia;

- Comunicar e associar objetivos e medidas estratégias;

- Planejar, estabelecer metas e alinhar iniciativas estratégicas;

- Melhorar o feedback e o aprendizado estratégico. 


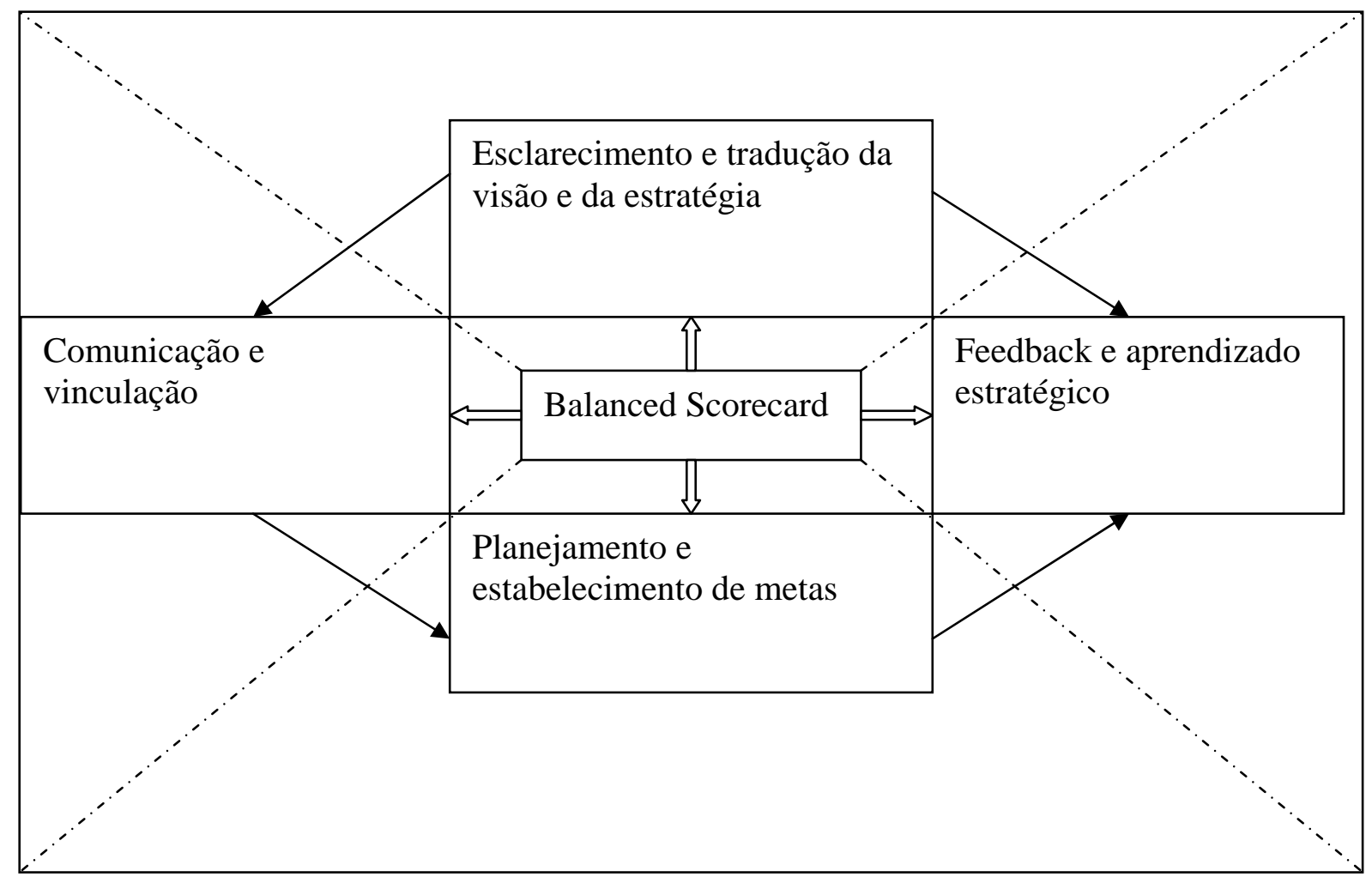

Quadro 5 Um sistema gerencial diferente - Planejamento e estabelecimento de metas.

Fonte: Kaplan e Norton (1997, p. 234).

Kaplan e Norton (1997) aponta o BSC como à solução de uma lacuna existente na maioria dos sistemas gerenciais - a falta de um processo sistemático para implementar e obter feedback sobre a estratégia. Para os autores, os processos gerenciais construídos a partir do Scorecard asseguram que a organização fique alinhada e focalizada na implementação da estratégia de longo prazo. Afirmam que o Balanced Scorecard é a base para o gerenciamento das organizações na era da informação, com ênfase na mensuração dos ativos intangíveis.

Para Carbone (2006, p. 109) “investir em métodos de mensuração de ativos intangíveis representa mais que uma necessidade empresarial. É uma necessidade do mercado global que pode dar mais justiça e equilíbrio às relações do mercado”. Afirmando ainda, que tal investimento não vai solucionar todos os problemas, mas pode minimizá-los.

Chiavenato e Sapiro (2003) classifica o BSC como um sistema de suporte à decisão, pois engloba os elementos-chave que permitem o acompanhamento e o cumprimento da estratégia. Afirma que ele abrange mais do que a tomada de decisão, focando também a comunicação da estratégia e o feedback de seu cumprimento.

Para Leal Filho (2005, p.88) “o uso do BSC ajuda a traduzir conceitos complexos e muitas vezes obscuros, em conceitos mais precisos, capazes de gerar o consenso entre funcionários e dirigentes”. 
Segundo Kaplan e Norton (1997) o Balanced Scorecard traduz a missão e a estratégia em objetivos e medidas, organizados em quatro perspectivas diferentes: financeira (retorno sobre o investimento e o valor econômico agregado), do cliente (satisfação, retenção, participação de mercado e de conta), dos processos internos (qualidade, tempo de resposta, custo e lançamento de novos produtos) e do aprendizado e crescimento (satisfação dos funcionários e disponibilidade de informações). Cria uma estrutura e uma linguagem para comunicar a missão e a estratégia, utilizando os indicadores para informar os vetores do sucesso atual e futuro da organização.

Para os autores da ferramenta esse conjunto de medidas serve de base para o sistema de medição e gestão estratégica que avalia o desempenho organizacional de modo equilibrado, tendo como foco as quatro perspectivas. Desse modo, permite o acompanhamento do desempenho das organizações e monitora, ao mesmo tempo, o progresso na construção de capacidades e na aquisição e manutenção de ativos intangíveis sem os quais o crescimento futuro fica comprometido.

Prieto et. al. (2006, p. 84) analisa os aspectos críticos na implementação do BSC apontando como "um dos problemas mais comuns o envolvimento do gerente nível sênior, a partir do momento em que os executivos passam a delegar toda a estratégia do processo de implementação ao nível hierárquico intermediário”. Argumenta que os gerentes intermediários podem não estar preparados para entender a estratégia nem o projeto do BSC como um todo e considerar o BSC simplesmente como um projeto para desenvolver métricas, em vez de um projeto de mudanças estratégicas que inclui cada detalhe da organização.

O STJ utiliza o sistema Balanced Scorecard como instrumento de gestão desde 2004. O plano de gestão 2006 - 2008 foi organizado nas quatro perspectivas definidas no modelo. A perspectiva cliente é denominada sociedade e a financeira é chamada orçamento. Para as outras duas perspectivas são empregadas a nomenclatura do modelo: processos internos e aprendizado e crescimento.

Sinottio (2008) apresenta como componentes do BSC: o Mapa estratégico que descreve a estratégia da empresa através de objetivos relacionados entre si e distribuídos nas quatro perspectivas; os Objetivos estratégicos - o que deve ser alcançado e o que é crítico para o sucesso da organização; os Indicadores - como é medido e acompanhado o sucesso do alcance do objetivo; a meta - nível de desempenho ou a taxa de melhoria necessária; o plano de ação - programas de ação-chave necessários para se alcançar os objetivos. 
Kaplan e Norton (2004, p. 55) analisando o mapa estratégico comenta: “O mapa estratégico descreve a lógica da estratégia, mostrando com clareza os objetivos dos processos internos críticos que criam valor e os ativos intangíveis necessários para respaldá-los”. Complementa ainda que o BSB traduz os objetivos do mapa estratégico em indicadores e metas.

Kaplan e Norton (1997, p.173) concluem: “O scorecard tem que contar a história da estratégia da unidade de negócios. Essa história é contada pela integração das medidas de resultados com os vetores de desempenho através de várias relações de causa e efeito”

Para Chiavenato e Sapiro (2003, p. 392) “A montagem do BSC passa pelas seguintes etapas: definição da estratégia; montagem do Mapa Estratégico; e montagem do BSC”. Segundo o autor existem três aspectos essenciais do BSC: fazer da estratégia a tarefa diária de cada pessoa da organização; fazer da estratégia um processo contínuo; e mobilizar a mudança por meio da liderança de executivos. 


\section{3 - Metodologia da Pesquisa}

O objetivo deste tópico é descrever a metodologia e as técnicas de pesquisa que foram adotadas no estudo da gestão estratégica do Superior Tribunal de Justiça de acordo com as abordagens até aqui descritas. A definição metodológica de uma pesquisa empírica é de fundamental importância para as pretensões do pesquisador, que deve informar adequadamente o que pretende investigar e a justificativa.

A seguir são descritos o tipo de pesquisa, os procedimentos a serem adotados e a forma de análise dos dados coletados.

\subsection{Classificação da pesquisa}

O tipo de pesquisa adotado é a qualitativa, de forma a analisar os aspectos relacionados ao desenvolvimento das práticas organizacionais. Para Godoy (1995) a pesquisa qualitativa envolve a obtenção de dados descritivos e a utilização de uma abordagem comparativa que busca o conhecimento, a explicação de fenômenos de interesse das ciências sociais por meio de um método capaz de descrever com exatidão todos os fatos e fenômenos inseridos numa determinada realidade.

Segundo Godoy (1995, p. 62) “os estudos denominados qualitativos têm como preocupação fundamental o estudo e a análise do mundo empírico em seu ambiente natural. Nessa abordagem valoriza-se o contato direto e prolongado do pesquisador com o ambiente e a situação que está sendo estudada”. Para a autora, “a palavra escrita ocupa lugar de destaque nessa abordagem, desempenhando um papel fundamental tanto no processo de obtenção dos dados quanto na disseminação dos resultados”. A autora conclui que (p. 63) “quando o estudo é de caráter descritivo e o que se busca é o entendimento do fenômeno como um todo, na sua complexidade, é possível que uma análise qualitativa seja a mais indicada”.

Em função da necessidade de conhecer informações sobre a implantação da gestão estratégica no STJ, foi adotada análise documental que segundo Mayring (2002 apud, Günther, 2006, p. 205) é um delineamento da pesquisa qualitativa.

\subsection{Amostra}

Foram coletados e analisados os documentos relacionados aos Planos de Gestão 20042006 e 2006-2008, os Relatórios de Gestão dos exercícios de 2005, 2006 e 2007, os 
Relatórios de desempenho mensais dos anos de 2005, 2006 e 2007 e os Resumos das Reuniões de acompanhamento do Plano de Gestão que ocorreram em Nov/06, Maio/07, Set/07 e Nov/07.

\subsection{Procedimentos}

Esta pesquisa teve por base a análise documental dos relatórios de gestão mensais e anuais do Superior Tribunal de Justiça. Procurou-se, inicialmente, retratar as metas, projetos e ações estratégicas. A seguir, foram elencados os resultados alcançados de forma individualizada e consolidada por objetivo estratégico e perspectiva, indicando-se os desvios em relação aos parâmetros definidos e as suas causas. Os instrumentos utilizados para o desenvolvimento deste estudo são a pesquisa bibliográfica e documental.

A pesquisa bibliográfica utiliza-se fundamentalmente das contribuições dos diversos autores como Leitão (1995), Kotter (1997), Senge at.al. (2000), Chiavenato e Sapiro (2003), Oliveira (2004), Freitas (2007), Kaplan e Norton (1997) entre outros que trazem informações dos variados assuntos tratados no estudo. A pesquisa documental, por sua vez, utiliza-se de materiais que não receberam tratamento analítico. As fontes de pesquisa documental são mais diversificadas e dispersas do que as da pesquisa bibliográfica. Conforme Gil (1994 apud ALBERTON, 1999), na pesquisa documental existe os documentos de primeira mão, ou seja, aqueles que não receberam nenhum tratamento analítico, tais como os documentos conservados em órgãos públicos e instituições privadas, e os documentos de segunda mão, que de alguma forma já foram analisados, tais como: relatórios de pesquisa; relatórios de empresas; tabelas estatísticas e outros.

Para Lüdke (1986, p. 38), "a análise documental pode se constituir numa técnica valiosa de abordagem de dados qualitativos, seja complementando as informações obtidas por outras técnicas, seja desvelando aspectos novos de um tema ou problema."

Godoy (1995, p. 65) manifesta opinião semelhante à Lüdke ressaltando que "a análise de documentos constitui-se numa valiosa técnica de abordagem de dados qualitativos, podendo ser também utilizada para complementar informação obtida em outras fontes”.

Segundo Caulley (1981 apud Lüdke, 1986, p. 38), “a análise documental busca identificar informações factuais nos documentos a partir de questões ou hipóteses de 
interesse”. Baseado nessa informação, a análise de um relatório de gestão poderia ser examinado no sentido de buscar evidências de que o planejamento estratégico está sendo observado, inclusive quanto aos resultados alcançados.

\subsection{1 - Coleta e análise dos dados da pesquisa}

A coleta dos dados e informações objeto de análise nesta pesquisa obedeceu ao esquema abaixo:

- Levantamento das bibliografias que contextualizam o ambiente atual e tratam da implantação de gestão estratégica;

- Descrição do processo de implantação da gestão estratégica no STJ a partir da pesquisa documental;

- Avaliação, de acordo com os registros documentais, do cumprimento das metas estabelecidas nas duas últimas gestões;

- Considerações sobre o processo de gestão estratégica no STJ e seus resultados. 


\section{4 - Análise dos resultados}

Em obediência às disposições regimentais (Art. 17 do Regimento Interno do STJ), a administração do STJ tem mandato de dois anos, a contar da posse, vedada a reeleição.

Em conseqüência dessa exigência regimental, o processo de planejamento estratégico do STJ obedece aos períodos de vigência de cada administração, ou seja, a cada dois anos é formalizado o plano estratégico para o mandato da administração que se inicia.

Os períodos que foram objeto de análise nesta pesquisa referem-se, portanto, a duas etapas distintas: o planejamento relativo ao biênio 2004-2006 e o relativo ao biênio 20062008.

Para os dois períodos, as metas vinculadas a cada programa/projeto são estabelecidas e acompanhadas mensalmente por cada unidade responsável e ao final do exercício é publicado um relatório de gestão que apresenta os resultados anuais.

Na pesquisa, foram analisados os resultados alcançados em cada ano, de 2004 a 2007. Os resultados de 2008 deixaram de ser analisados, tendo em vista que sua publicação deverá ocorrer, possivelmente, até o final do primeiro trimestre de 2009.

Em setembro/2004 o Superior Tribunal de Justiça iniciou formalmente a implementação do planejamento estratégico, publicando o Plano Estratégico 2004-2006, que estabelecia 16 metas e 32 projetos estratégicos a serem alcançadas até dezembro/2006. Dessa forma, 2005 foi o primeiro ano completo com metas institucionais, sendo elaborado o Relatório de Gestão - exercício 2005, no qual foram apresentadas as informações agrupadas nas quatro estratégias de ação que foram definidas, na Gestão 2004-2006 (conforme demonstrado no mapa estratégico no Anexo 1): garantir uma prestação jurisdicional efetiva e transparente; agilizar a prestação jurisdicional; aproximar o Tribunal da sociedade; e contribuir para expansão e modernização do Judiciário.

Em abril/2006 houve mudança Regimental e em decorrência foi publicado o Plano de Gestão 2006-2008, que continuou com o modelo de planejamento da Gestão anterior, trazendo algumas alterações/inovações. Foram estabelecidas vinte metas e dez objetivos estratégicos a serem atingidos até dezembro/2007, propondo ainda ações e/ou projetos estratégicos de curto, médio e longo prazo.

No Relatório de Gestão - exercício 2006 e 2007, os resultados foram apresentados de 
forma agrupada, por perspectivas, como definido no modelo de sistema gerencial denominado Balanced Scorecard, estudado no item 2.4 do referencial teórico. O alinhamento de objetivos, indicadores, metas e iniciativas estão enquadradas nas quatro perspectivas a seguir:

- Perspectiva 1 - Sociedade: essa perspectiva de atuação visa o atendimento das demandas e das expectativas da sociedade, com eficiência. Abrange dois objetivos estratégicos:

o Oferecer serviços com qualidade: trabalho com foco no cidadão e execução das atividades com eficiência, eficácia e efetividade, buscando a melhoria contínua do desempenho.

- Projetos e ações:

- Ações de melhoria para 15 serviços oferecidos aos clientes do STJ (avaliados na pesquisa de satisfação do cliente externo): autuação, classificação e distribuição; certidões judiciais; controle de acesso; informações processuais; instalações físicas; pesquisa de jurisprudência; pesquisa de documentos administrativos e judiciários; pesquisa de doutrina e legislação; protocolo de petições; publicação de acórdãos; revista eletrônica; serviços cartorários; sistema push; site do STJ; notícias.

- Projeto Petição Eletrônica: sistema de recebimento de petições e documentos transmitidos por meio eletrônico, assinados digitalmente, com certificação de autenticidade de autoria e dispensa de remessa posterior de originais.

- Levantar as causas da recorribilidade nas decisões, identificando tribunais em que os processos se originam, matéria discutida, Órgão Julgador, Partes (bancos, entes públicos, grandes empresas).

- Projeto Jurisprudência nos Estados - divulgar nos Estados as ferramentas e mecanismos de recuperação da jurisprudência do Superior Tribunal de Justiça, mediante palestras presenciais e distribuição de material de apoio. 
- Projeto Jurisprudência Comparada - elaborar periódico de jurisprudência, datado e numerado, com seleção de temas jurídicos divergentes e pacíficos no Superior Tribunal de Justiça e no Supremo Tribunal Federal, a ser distribuído diretamente aos Senhores Ministros em cada julgamento de Seção.

o Ampliar a responsabilidade sócio ambiental: atuar para a garantia da cidadania e para a gestão ambiental, por meio de ações educativas, de inclusão social.

- Projetos e ações:

- Projeto STJ Ambiental - inserir critérios ecologicamente adequados nas práticas de gestão do STJ e preparar os servidores para atuar com consciência ambiental, contribuindo para o desenvolvimento sustentado.

- Projeto Sociedade p/todas as idades.

- Projeto Despertar Vocacional Jurídico/Museu-Escola.

- Projeto Voluntariado/Supletivo.

- Estágio não-remunerado.

- Cartilha básica de Direito.

- Acessibilidade e inclusão de Pessoas com Deficiência.

- Perspectiva 2 - Processos internos: Voltada basicamente para a celeridade da prestação jurisdicional, inibindo a morosidade no Judiciário e melhorando a produtividade, de forma a diminuir significativamente o passivo de processos no Tribunal. Abrange os seguintes objetivos estratégicos:

o Elevar a produção de julgados: aumentar o número de julgados do STJ, para atender melhor à demanda da sociedade.

- Projetos e ações:

- Projeto Modernização dos Julgamentos - incrementar estrutura e procedimentos e criar funcionalidades de sistema para agilizar os julgamentos colegiados do Superior Tribunal de Justiça, desde a inclusão do processo em pauta para julgamento até a publicação do acórdão. 
- Certificação digital - adequar a Infra-estrutura de Tecnologia da Informação do STJ para a utilização de Certificados Digitais emitidos sob a Autoridade Certificadora da Justiça, AC-JUS, incluindo a disponibilização dos certificados digitais aos usuários, bem como equipamentos necessários à sua utilização.

- Catálogo de questões jurídicas (em fase de implantação).

- Atualização do Regimento Interno do STJ.

- Otimização do Trâmite Processual.

- Revisão dos Sistemas Informatizados.

- Fábrica de Software.

o Acelerar o trâmite processual: reduzir o tempo de tramitação dos processos no STJ.

- Projetos e ações - contempla os mesmos projetos vinculados ao objetivo anterior.

o Manter em patamares elevados o conceito do Tribunal perante a sociedade: melhorar a imagem institucional por meio de comunicação objetiva, clara e acessível.

- Projetos e ações:

- Política de Comunicação Social - instituir um instrumento orientador para sistematizar as ações de comunicação, com vistas a nortear o relacionamento institucional com seu públicoalvo e comunicar as estratégias da Organização.

- Programas STJ na TV e Fala STJ - esses projetos visam divulgar matérias de rádio e TV, com as principais decisões da Corte, e programas institucionais curtos que mostrarão, de forma didática, o que é, para que serve e como funciona o Superior Tribunal de Justiça.

- Perspectiva 3 - Aprendizado e crescimento: Foco no investimento nas pessoas e na infra-estrutura. Abrange os seguintes objetivos estratégicos 
o Contribuir para a modernização do judiciário: investir em novos conhecimentos e recursos tecnológicos e desenvolver ações conjuntas com outros órgãos e instituições, para a reforma, expansão e modernização do Judiciário.

- Projetos e ações:

- Projeto Integração Tecnológica do Poder Judiciário.

- Consórcio BDJur.

- Processo Digital.

- Gestões junto ao Congresso Nacional para aprovação de Projetos de Lei de interesse do STJ e daqueles relacionados à modernização das leis processuais, como, por exemplo, maior regramento para admissibilidade do Recurso Especial e a implantação da Súmula Impeditiva do Recurso.

o Desenvolver competências: qualificar servidores e gestores para melhor desempenho de suas atribuições, com vistas ao cumprimento das metas institucionais, e para assumirem encargos e maior complexidade e responsabilidade.

- Projetos e ações:

- Projeto Gestão por Competências.

- Projeto Escola Nacional de Formação e Aperfeiçoamento dos Magistrados - ENFAM.

- Projeto Educação Corporativa

o Melhorar o clima organizacional: aumentar a satisfação dos servidores quanto à gestão de processos, aos recursos e condições ambientais, à comunicação interna, à liderança, à motivação, à visão sistêmica e ao relacionamento.

- Projetos e ações:

- Programa Bem-Estar do Servidor.

- Manual de Atos Oficiais Administrativos.

- Projeto Construção do Restaurante. 
- Programa de Assistência Médica e Social.

- Programa de Modernização Administrativa.

- Perspectiva 4 - Orçamento: Refere-se à viabilização da disponibilidade financeira indispensável ao cumprimento das metas institucionais. Para esta perspectiva foi definido apenas um objetivo:

o Assegurar e gerir recursos orçamentários e financeiros: garantir os recursos de custeio e investimento indispensáveis ao funcionamento do Tribunal e ao cumprimento de objetivos e metas estabelecidos, observando em sua execução os princípios norteadores da gestão pública.

- Projetos e ações:

- Sistema de avaliação de custos - implantar um sistema de apuração de custos para calcular o dispêndio de recursos na prestação jurisdicional do STJ, ao longo do tempo, e aferir o custo total de cada processo (sentença do tribunal), mediante a identificação dos custos que cada unidade agrega.

- Negociações junto aos fornecedores, dos contratos de serviços continuados, visando a economia constante de recursos.

- Ações de melhoria das despesas previstas no planejamento orçamentário, avaliando e aperfeiçoando os instrumentos de gestão administrativa e financeira do Tribunal.

A estrutura de apresentação dos resultados segue o mesmo esquema de objetivos e perspectivas.

No anexo B consta o Mapa Estratégico do Plano de Gestão 2006 - 2008 do STJ, onde destacam-se: a missão do STJ, a visão de futuro, as perspectivas e seus objetivos. Segundo Kaplan e Norton (2004) o Mapa Estratégico é uma importante ferramenta para traduzir o pensamento da administração e constitui peça fundamental de comunicação do planejamento. 


\section{1 - Análise das metas e resultados relativos à Perspectiva 1 - Sociedade}

Essa perspectiva de atuação visa o atendimento das demandas e das expectativas da sociedade, com eficiência. Abrange os objetivos estratégicos de oferecer serviços com qualidade e de ampliar a responsabilidade sócio ambiental.

\subsection{1 - Objetivo Estratégico: oferecer serviços som qualidade}

Meta 1: atingir $90 \%$ de satisfação do usuário externo até novembro/2005. No plano de gestão 2006/2008 o índice foi revisado para $80 \%$ de satisfação do usuário externo até dezembro/2007.

a) Justificativa: atingir a excelência no nível de satisfação dos usuários quanto aos serviços/infra-estrutura oferecidos pelo tribunal.

b) Indicador de efetividade: Índice de satisfação do usuário. Mede o percentual de satisfação dos usuários externos com os serviços/infra-estrutura oferecidos, por meio de questionário disponível na internet. A pesquisa avalia os seguintes itens: Atendimento ao público, Autuação, Classificação e Distribuição de Processos, Certidões judiciais, Controle de acesso às dependências do STJ, Informações processuais, Instalações físicas do STJ, Pesquisa de jurisprudência, Pesquisas de documentos administrativos e judiciários, Pesquisas de doutrina e legislação, Protocolo de petições, Publicação de acórdãos, Revista Eletrônica, Serviços Cartorários, Sistema PUSH, Site do STJ, Ouvidoria e Notícias.

c) Forma de apuração dos resultados: Somatório das avaliações Bom (B) e Ótimo (O) do mês, dividido pelo total de avaliações do mês, multiplicado por 100. (os dados são obtidos por meio do sistema informatizado para pesquisa de satisfação - Sistema Gestor Internet).

$$
\underline{(\mathrm{B}+\mathrm{O}) \times 100}
$$

Total

d) Resultados alcançados (ver gráfico da página seguinte):

No primeiro semestre de 2005, o índice de satisfação dos usuários alcançou 76\%, abaixo da meta estipulada de 90\%. Nos meses de outubro e novembro de 2005 ocorreu uma pequena queda no índice de satisfação. Considerando todo o ano de 2005, o índice alcançado foi 70\%, concluindo-se que houve superestimação do percentual fixado (90\%).

A queda no índice de avaliação no segundo semestre de 2005 foi interpretada como sendo uma conseqüência do método avaliativo adotado que manteve o mesmo questionário disponibilizado de forma permanente na Internet, o que induziu o usuário a usá-lo como canal de reclamação. (Fonte: Relatório de Gestão 2005). 


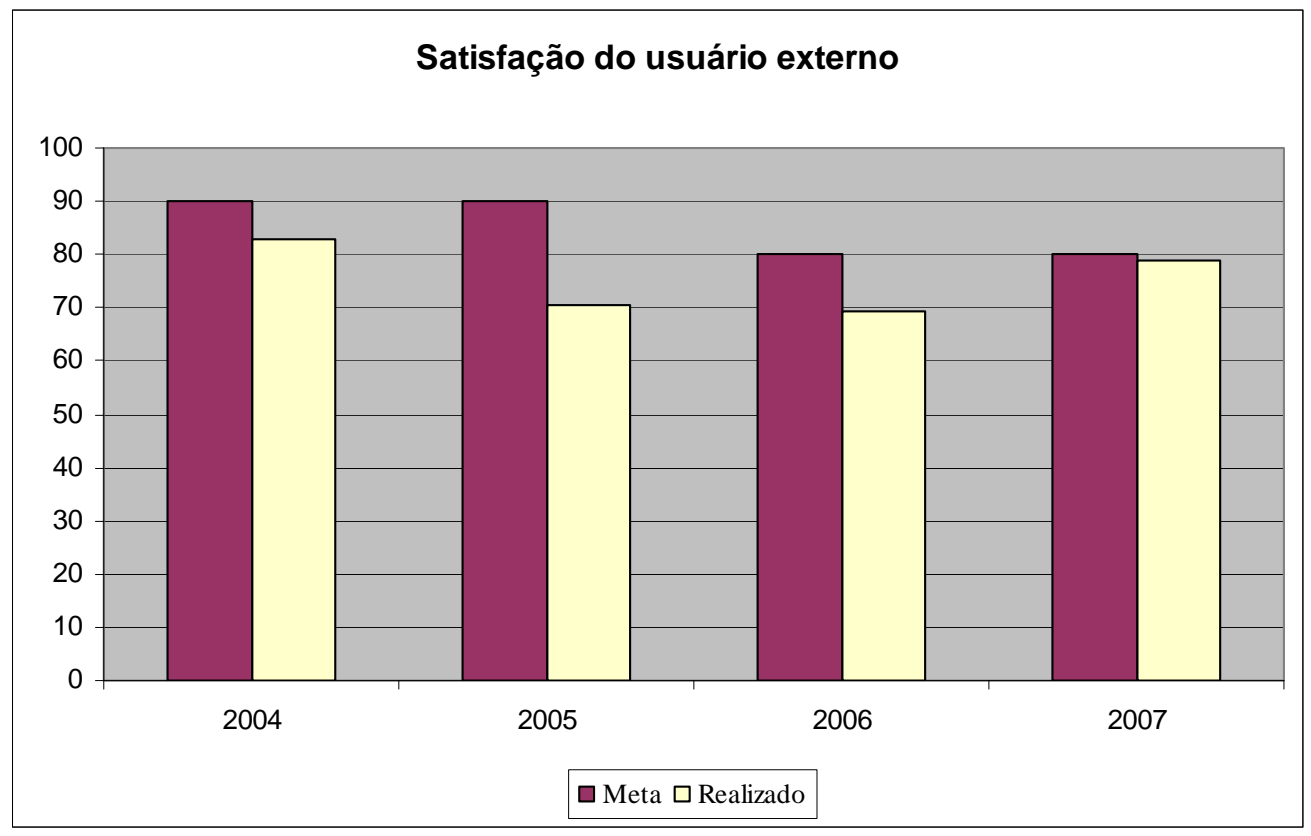

Gráfico 1 - Satisfação do usuário externo.

Fonte: Relatórios de Gestão - Exercícios 2005, 2006 e 2007.

As metas para 2006 e 2007 foram revisadas para 80\%.

Em 2006 o resultado obtido foi 69,23\% de satisfação com 131.537 respondentes, sendo que todas as reclamações e sugestões apresentadas pelos usuários foram tratadas e respondidas por intermédio da ouvidoria do STJ. (Fonte: Relatório de Gestão 2006).

Já em 2007, a meta foi avaliada mês a mês, chegando a dezembro com índice de $78,71 \%$, 1,29\% p.p abaixo da meta de $80 \%$. Todas as reclamações e sugestões são tratadas e respondidas através da ouvidoria do STJ. (Fonte: Relatório de Gestão 2007).

\section{Meta 2: reduzir em 10\% a taxa de recorribilidade interna, até dezembro/2007.}

a) Justificativa: Aumentar a efetividade das decisões do STJ, reduzindo o número de recursos interpostos.

b) Indicador: taxa de recorribilidade interna. Mede a relação entre recursos interpostos e decisões publicadas pelo STJ.

c) Forma de apurar os resultados: Somatório dos recursos interpostos em acórdãos (RIC) e em decisões monocráticas (RDM) do mês, dividido pelo total de decisões publicadas (DP) do mês, multiplicado por 100. (RIC + RDM) x 100

$\mathrm{DP}$

d) Resultados alcançados (ver gráfico da página seguinte): 


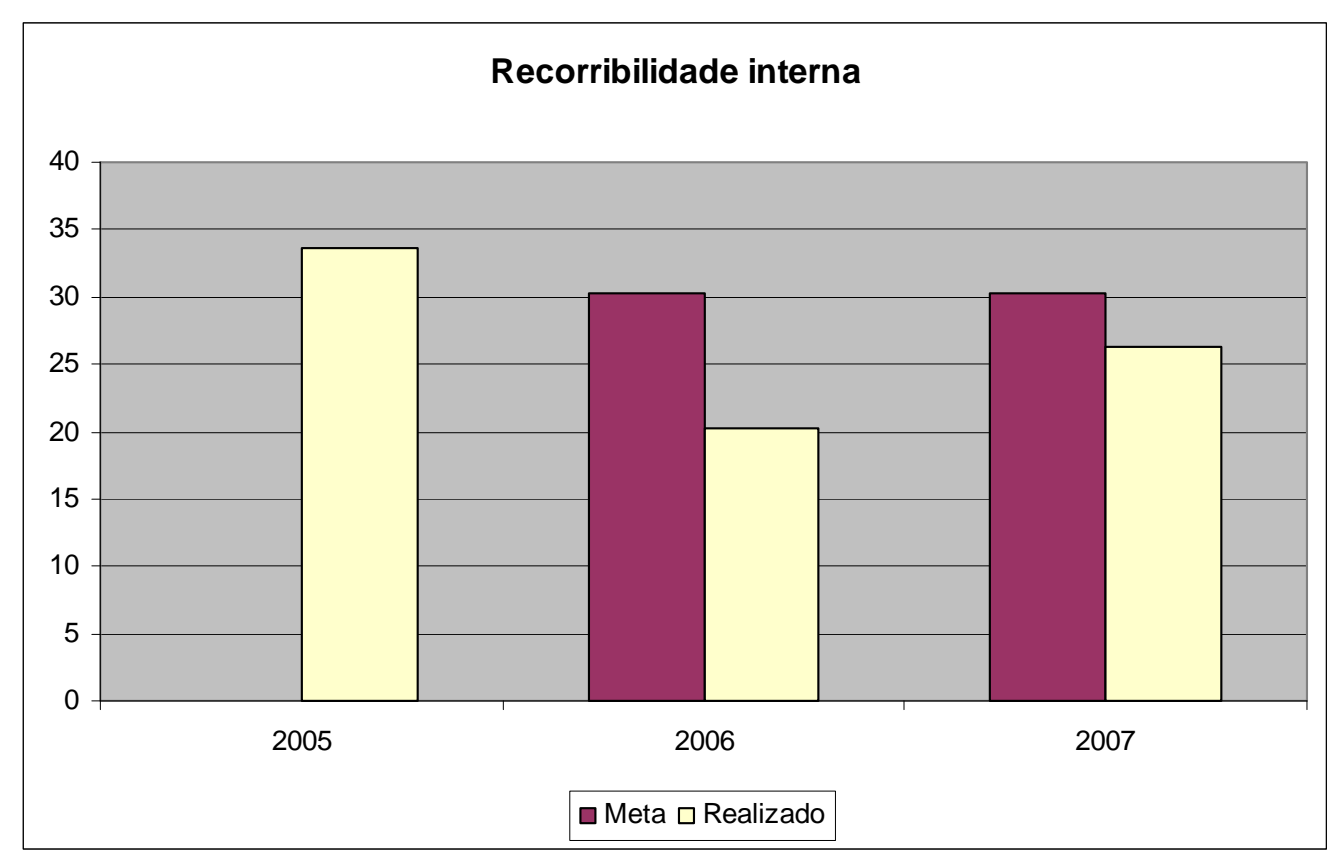

Gráfico 2 - Recorribilidade interna.

Fonte: Relatórios de Gestão - Exercícios 2006 e 2007.

Em 2006, a redução na taxa de recorribilidade interna foi de 18,37\%, superando à meta de 10\% estabelecida para esse indicador. Registrou-se uma redução de 45,36\% em relação a 2005. Entretanto, como a iniciativa de mensuração desse indicador é pioneira no STJ, ressalta-se a necessidade de observar melhor seu desempenho ao longo do tempo para identificar variações, estabilidades e sazonalidades. Foi criado um grupo de estudos com a finalidade de analisar as causas da recorribilidade interna e propor ações de melhoria. Esse grupo está empenhado em realizar um levantamento mais apurado para indicar precisamente os pontos a serem abordados. (Fonte: Relatório de Gestão 2006).

Em 2007 a taxa de recorribilidade situou-se em 26,27\%, abaixo do limite máximo de 30\%. O grupo de estudos criado em 2006 com a finalidade de analisar as causas da recorribilidade interna e propor ações de melhoria não identificou causas especificas, devido à grande diversidade de fatores envolvidos, e apontou para a necessidade de cada gabinete analisar as próprias taxas, a fim de identificar as causas e tratá-las internamente. O assunto foi discutido em reunião de análise estratégica com a alta administração do Tribunal, que decidiu por um valor mais desafiador para a meta em 2008 - manter a recorribilidade interna abaixo de 25\%. (Fonte: Relatório de Gestão 2007). 
Meta 3: reduzir em $10 \%$ a taxa de reforma interna da decisão no STJ, até dezembro/2007

a) Justificativa: desestimular a interposição de recursos. As decisões revelam-se mais consistentes quando são ratificadas pela instância recursal.

b) Indicador: taxa de reforma interna da decisão. A meta visa contribuir para a qualidade dos serviços prestados ao cidadão tendo em vista a segurança gerada pela unidade interpretativa dos Órgãos Julgadores. Medindo a relação entre recursos julgados e recursos providos (ainda que parcialmente).

c) Forma de apuração dos resultados: Somatório dos Agravos Regimentais Providos (ARP) e Embargos de Declaração Providos (EDP) do mês dividido pelo total de recursos julgados (TRJ) do mês, multiplicado por 100. (ARP + EDP) $\times 100$

TRJ

d) Resultados alcançados:

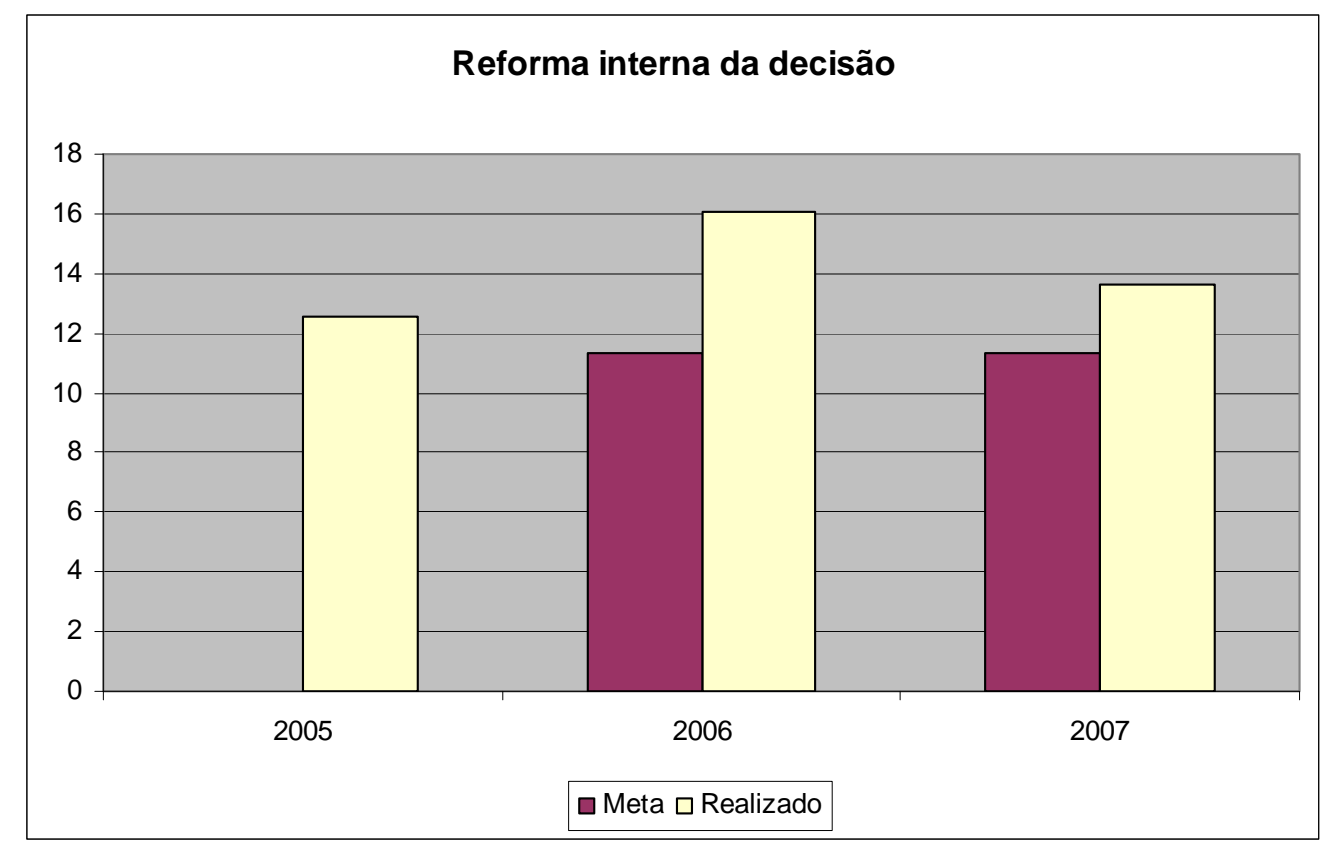

Gráfico 3 - Reforma interna da decisão.

Fonte: Relatórios de Gestão - Exercícios 2006 e 2007.

Conforme verificado no gráfico, o percentual de reforma interna da decisão situou-se acima do esperado, já que a meta estabelecia como limite máximo de reforma da decisão o percentual de 11,33\% dos julgados (o índice teve por base a reforma interna em 2005 que mediu 12,58\%) comparativamente aos 16,08\% efetivamente ocorridos em 2006. No entanto, como se tratou do primeiro ciclo de mensuração do indicador há que se observar melhor o desempenho da referida taxa ao longo do tempo para identificar variações, estabilidades e 
sazonalidades. As causas da reforma interna serão analisadas pelo mesmo grupo de estudos responsável pela recorribilidade. (Fonte: Relatório de Gestão 2006)

Em 2007, o limite foi novamente descumprido, verificando-se reforma de decisão interna em 13,59\% dos julgados. A análise dos dados resultou na decisão administrativa de alterar a meta para 2008 - manter a reforma interna abaixo de 12\% - com adoção de algumas medidas corretivas, como a distribuição de gráficos com os resultados mensais aos Ministros, propiciando a gestão à vista e o monitoramento dos resultados. Foram definidas e acompanhadas metas individuais para os gabinetes, englobando os aspectos produção, tempo de trâmite, estoque de processos, reforma e recorribilidade de decisões. (Fonte: Relatório de Gestão 2007).

\subsection{2 - Objetivo estratégico: ampliar a responsabilidade sócio-ambiental}

\section{Meta 4: reduzir em 20\% o impacto ambiental causado pelo STJ, até dezembro/2007.}

a) Justificativa: Diminuir o impacto causado pelo STJ no meio ambiente, realizando ações voltadas para a responsabilidade ambiental.

b) Indicador de eficácia: índice de redução do impacto ambiental. Reduzir em $20 \%$ o impacto ambiental até dezembro/2007. Com a intenção de minimizar os efeitos negativos causados pelo STJ no meio ambiente com a economia no consumo de papel, energia elétrica e água e com o tratamento adequado dos resíduos sólidos e tóxicos. A meta mede o índice de redução do consumo de papel, de economia de energia elétrica e água e de tratamento adequado dos resíduos sólidos e tóxicos.

c) Forma de apuração dos resultados: Somatório dos Índices de Redução de Consumo de Papel (IRCP), de Economia de Energia Elétrica (IEEE), de Economia de Água (IEA), de Tratamento dos Resíduos Sólidos (ITRS) e de Tratamento e Descontaminação de Lâmpadas Fluorescentes (ITDLF) do ano. Os três primeiros itens recebem um peso maior por trazerem economia financeira para o STJ.

$\underline{\text { IRCP x 23,3 + IEEE x 23,3 + IEA x 23,3 + ITRS x } 15 \text { + ITDLF x } 15}$ 100

Obs.: Calculado a partir dos índices do exercício anterior.

d) Resultados alcançados (ver gráfico na página seguinte):

Conforme demonstrado no gráfico abaixo os resultados obtidos em dezembro/2006 estão 1,5\% abaixo da meta, com uma redução de 18,5\% do impacto ambiental. Foram identificados aumentos no consumo de energia elétrica e de papel, os quais serão objeto de 


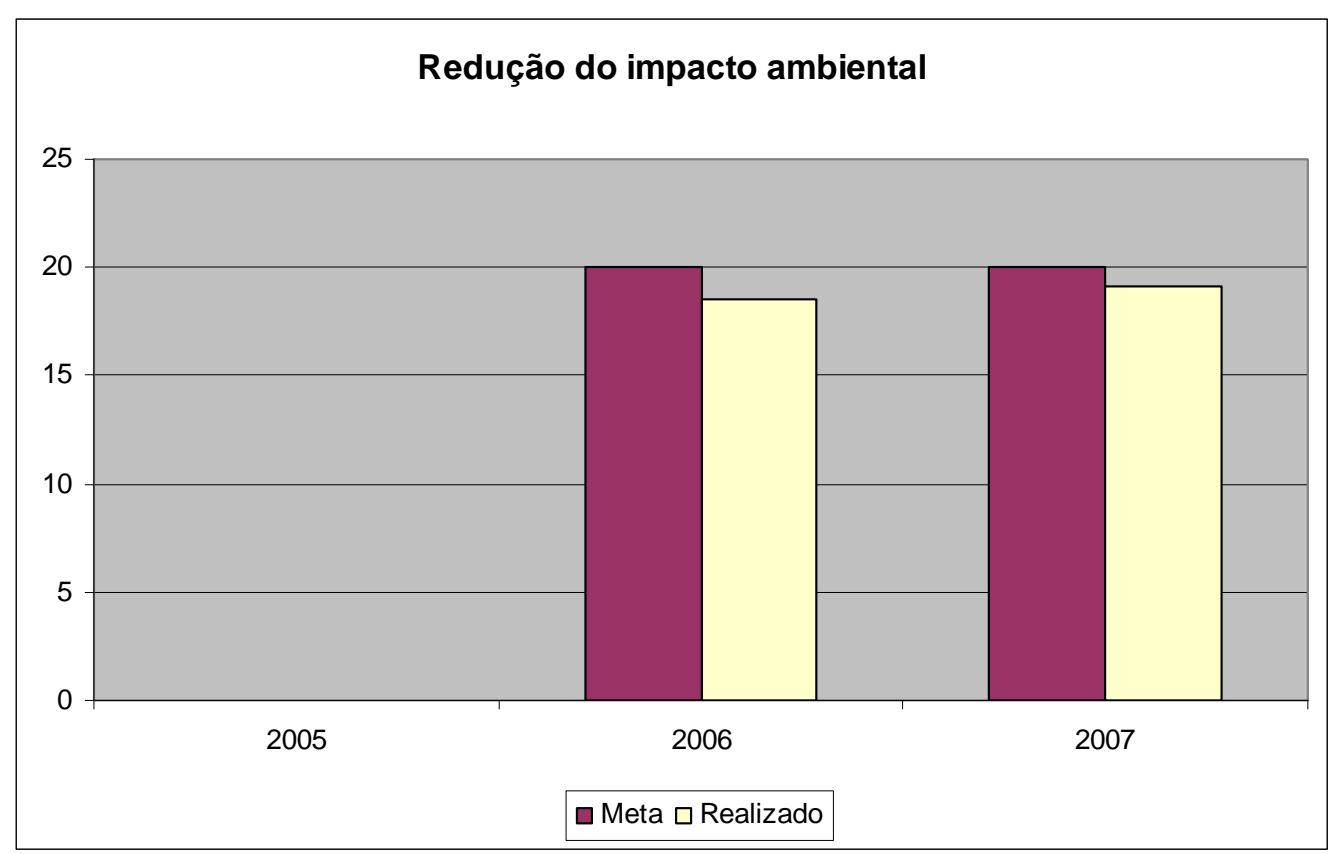

Gráfico 4 - Redução do impacto ambiental.

Fonte: Relatórios de Gestão - Exercícios 2006 e 2007.

tratamento específico em campanhas educativas para 2007. (Fonte: Relatório de Gestão 2006).

Em 2007 os dados apurados mostram-se mais próximos do almejado, registrando-se redução de 19,11\%, necessitando, porém, de algumas ações mais específicas. É o caso do consumo de papel, cujo aumento foi de 6,6\%, justificado pela elevação do número de processos tramitados no ano. Outro fator relevante foi o aumento do consumo de energia elétrica, item cuja melhoria necessita de campanha de sensibilização dos servidores e demais colaboradores, prevista para o próximo exercício. (Fonte: Relatório de Gestão 2007).

Para 2008, estão sendo negociadas, ainda, com as áreas responsáveis, metas específicas para cada item que compõe o indicador, conforme definido em reunião de análise estratégica com a alta administração. (Fonte: Relatório de Gestão 2007).

Meta 5: implantar dois projetos novos de cidadania até novembro/2005. No plano de gestão 2006/2008 a meta foi reformulada e passou a ser apurada pelo número de pessoas beneficiadas pelos projetos de cidadania sendo 6.000 para 2006 e 10.000 para 2007.

a) Justificativa: promover a responsabilidade social por meio de ações de cidadania voltadas para públicos específicos.

b) Indicador de eficácia: número de pessoas beneficiadas pelos projetos de cidadania. Mede o número de pessoas que usufruem das ações de cidadania implantadas no STJ.

c) Forma de apuração dos resultados: Somatório mensal das pessoas beneficiadas pelos 
diversos projetos de cidadania

d) Resultados alcançados:

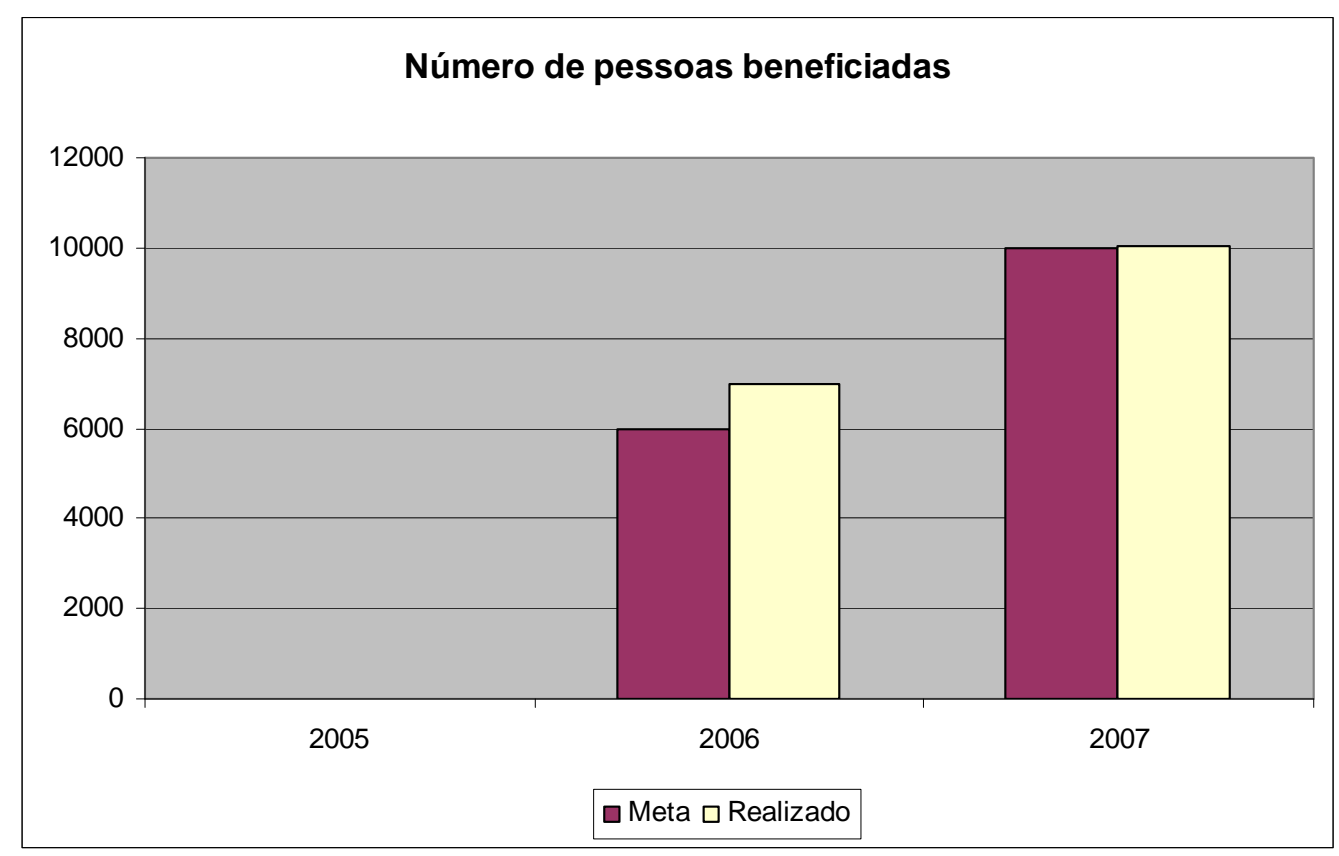

Gráfico 5 - Número de pessoas beneficiadas pelos projetos de cidadania.

Fonte: Relatórios de Gestão - Exercícios 2006 e 2007.

A meta criada em 2004 era implantar dois projetos novos de cidadania voltados para a responsabilidade social e ambiental do STJ. Os dois projetos propostos foram de voluntariado e de acessibilidade e inclusão de idosos e portadores de deficiência. O primeiro foi implantado totalmente, enquanto o segundo foi executado em cerca de 70\%. O projeto acessibilidade não foi concluído no prazo porque a necessidade de obras de adaptação foi maior do que a inicialmente prevista, fazendo que a execução se estendesse para a próxima gestão. Dessa forma considera-se que a meta não foi cumprida, ficando aquém do planejado. (Fonte: Relatório de Gestão 2005).

Para o período 2006 - 2008 o índice passou a ser calculado levando-se em conta o número de pessoas beneficiadas com os projetos. Estabeleceu-se a meta de 6.000 pessoas beneficiadas, até dezembro/2006, com os projetos de cidadania. A meta foi superada em 2006 e revista para 10.000 pessoas beneficiadas em 2007, cujo limite foi também superado. (Fonte: Relatório de Gestão 2006 e 2007). 


\section{2 - Análise das metas e resultados relativos à Perspectiva 2 - Processos internos}

Essa perspectiva está relacionada com a celeridade da prestação jurisdicional, inibindo a morosidade no Judiciário e melhorando a produtividade, de forma a diminuir significativamente o passivo de processos no Tribunal. Abrange os objetivos estratégicos de elevar a produção de julgados; acelerar o trâmite processual; e manter em patamares elevados o conceito do Tribunal perante a sociedade.

\subsection{1 - Objetivo estratégico: elevar a produção de julgados}

Meta 6: aumentar a produção de julgados em $30 \%$, até novembro/2005. Esse percentual foi mantido para os anos de 2006 e 2007

a) Justificativa: ampliar o atendimento da demanda e evitar o acúmulo de processos no Tribunal.

b) Indicador de eficácia: índice de aumento na produção. Mede o percentual de aumento de processos julgados em relação à média dos últimos cinco anos.

c) Forma de apuração dos resultados: Total de Processos Baixados Acumulado no Ano (TPBAA), dividido pela Média Acumulada de Baixados nos últimos 5 Anos (MAB5A), menos 1, multiplicado por 100. (TPBAA -1) X 100

\section{MAB5A}

d) Resultados alcançados (ver gráfico na página seguinte)::

Conforme demonstrado no gráfico abaixo em 2005, o Tribunal conseguiu julgar 271.428 processos, o que representa um aumento de 38\% na produção superando a meta estabelecida de 30\%. Esses números certamente representam um dos principais resultados da gestão 2004-2006, visto o seu impacto para os jurisdicionados. (Fonte: Relatório de Gestão 2005).

Já em 2006, foram julgados 262.343 processos, o que representa um aumento de 19,21\% na produção, situando-se abaixo da meta estipulada de 30\%. A queda dos valores apurados a partir de março pode ser explicada pela greve dos servidores, que gerou impacto na distribuição dos processos e na preparação dos mesmos para julgamento, e pelo quadro desfalcado de quatro Ministros ao longo do primeiro semestre daquele ano, dois deles tendo requerido aposentadoria voluntária em novembro de 2005 e outros dois em fevereiro e março de 2006. O prazo médio em que o gabinete fica vago entre a aposentadoria do Ministro anterior e a nomeação de novo Ministro é de seis meses. (Fonte: Relatório de Gestão 2006). 


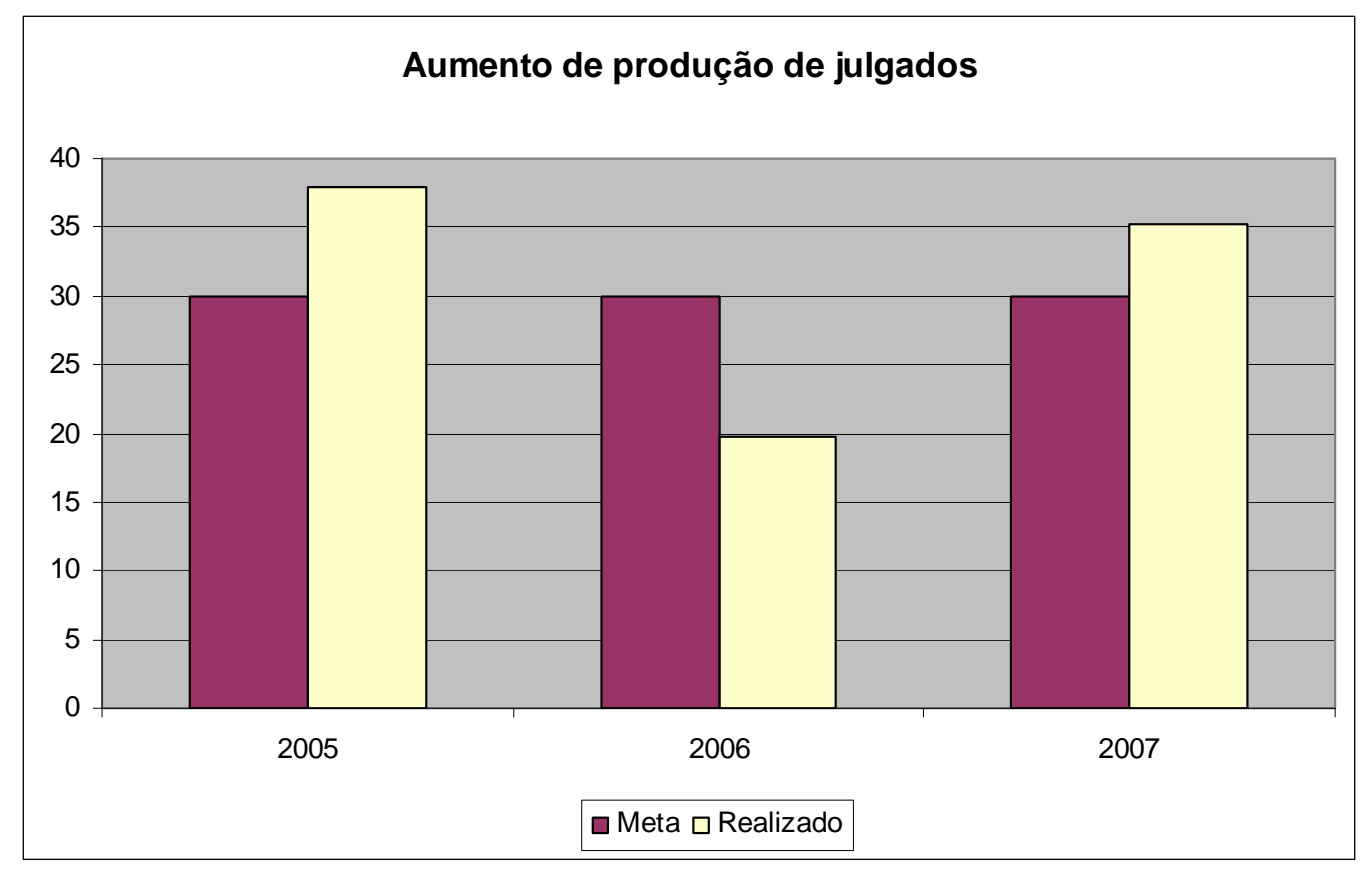

Gráfico 6 - Aumento da produção de julgados.

Fonte: Relatórios de Gestão - Exercícios 2005, 2006 e 2007.

Para melhor expressar esse índice, foi proposta alteração na medição desse indicador, passando-se a observar, a partir de 2007, o aumento em 30\% incidentes na produção de processos baixados e não apenas nos processos julgados. Já considerando essa nova forma, registrou-se um aumento de 37,09\% em dezembro de 2007, superando a meta prevista de 30\%. Entretanto, há a necessidade de rever essa meta no futuro, tendo em vista que, permanecendo a mesma demanda observada nos anos anteriores, não será possível reduzir o passivo atualmente existente, situado em torno de 240 mil processos. Nesse sentido, passariam a ser reforçadas linhas de atuação no âmbito externo, visando criar mecanismos para que a solução dos litígios se dê nas instâncias inferiores. (Fonte: Relatório de Gestão 2007)

Meta 7: reduzir em $30 \%$ o passivo de processos, até novembro/2005. A meta foi revista para 25\% nos anos de 2006 e 2007.

a) Justificativa: reduzir a taxa de congestionamento e o espaço físico ocupado pelo estoque de processos.

b) Indicador de efetividade: índice de redução de passivo. Mede o percentual de redução no quantitativo de processos em tramitação no Tribunal. 
c) Forma de apuração dos resultados: Processos Pendentes ao final do mês anterior (PPMA), dividido pelo somatório de Processos Pendentes quando da Definição da Meta (PPDM), menos 1 , vezes 100 .

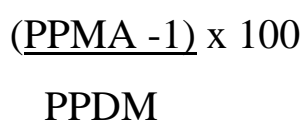

A contagem dos processos são efetuadas nas várias etapas da Cadeia de Valor: 1 Protocolo; 2 - Autuação; 3 - Classificação; 4 - Encaminhamento (distribuição); 5 Julgamento; 6 - Processamento; 7 - Publicação; 8 - Baixa.

d) Resultados alcançados:

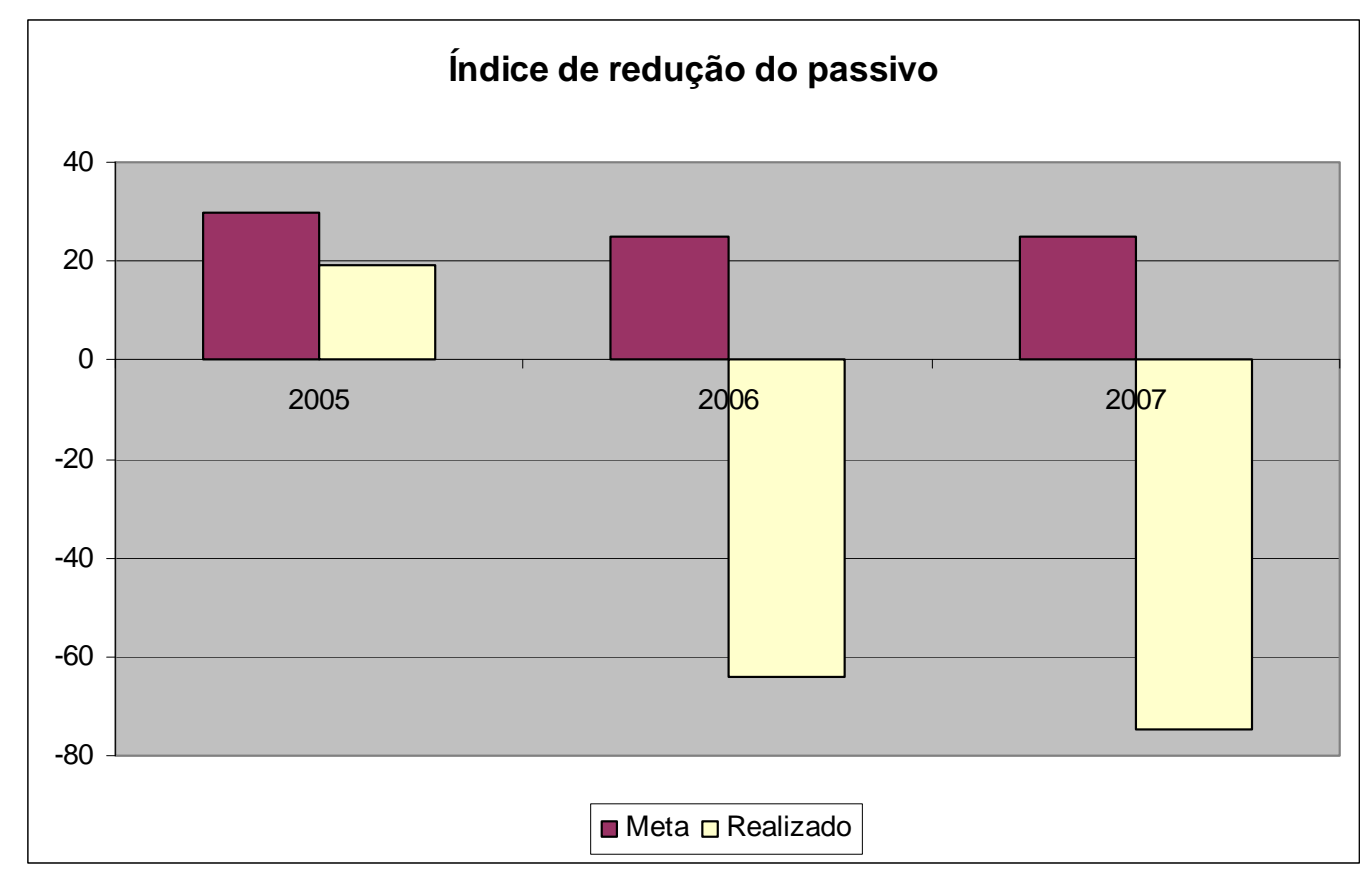

Gráfico 7 - Índice de redução do passivo.

Fonte: Relatórios de Gestão - Exercícios 2005, 2006 e 2007.

Conforme apresentado no gráfico em 2005, a meta não foi cumprida. Considerando a situação inicial, em julho/2004, quando o quantitativo era de 170 mil processos, houve uma diminuição de 19,4\% no passivo, quando a meta estabelecida era de 30\% . Esse desempenho representou redução de 33 mil na quantidade de processos existentes no Tribunal. Foram implementadas ações corretivas, visando à obtenção de melhores resultados para os próximos anos. (Fonte: Relatório de Gestão 2005)

Já em 2006, a meta foi redimensionada para reduzir em 25\% o passivo de processos, até dezembro/2007. No entanto, em 2006 o indicador se encontrava em situação preocupante. O estoque, ao invés de diminuir, apresentou um aumento de cerca de 64\% em relação ao início do ano, chegando a mais de 224.000 processos. Esse fato também encontra explicação 
nos fatores relatados na meta anterior (greve de servidores e demora na substituição de quatro Ministros) e principalmente no aumento massivo de 25,44\% da demanda de processos que chegam ao Tribunal, ou seja, cerca de 56.000 feitos a mais em relação a 2005. A Administração está agindo no sentido de priorizar as medidas que impactam diretamente na meta, com ações de otimização do trâmite processual nos Gabinetes de Ministros e Órgãos Julgadores. Da mesma forma, a Secretaria Judiciária formulou plano de ação para que os processos pendentes de distribuição estejam próximos à zero até junho de 2007. Por fim, foi aprovada a resolução n. ${ }^{0}$ 4, de 30 de novembro de 2006, que permite que o Ministro Presidente negue conhecimento ao agravo de instrumento manifestamente inadmissível antes de sua distribuição. Essa iniciativa será implementada já a partir de fevereiro de 2007 e agilizará sobremaneira a decisão nesses casos, diminuindo o volume de processos. (Fonte: Relatório de Gestão 2006).

Também em 2007 o indicador continuou em situação crítica. O passivo apresentou uma queda razoável no segundo semestre (de 264.995 processos em julho para 239.216 em dezembro), mas o resultado está longe do desejado. A demanda subiu 10\% em relação ao ano passado, que já havia sido 25\% maior que 2005. Esses valores representam uma média de 1.256 processos por dia chegando ao Tribunal e um acréscimo de 140 mil processos nos últimos dois anos. Dentre as ações já realizadas visando minimizar os impactos do acúmulo de processos está à criação do Núcleo de Agravos da Presidência, para processar aqueles manifestamente inadmissíveis, as ações de melhoria nos processos de trabalho, a criação de forças-tarefas para atuação em gabinetes e a convocação de desembargadores em substituição de Ministros. Apesar de recentes, essas iniciativas já significaram um incremento de mais de 29.500 julgados. (Fonte: Relatório de Gestão 2007).

Por outro lado, é importante frisar que essa meta também depende fortemente de um fator externo que não está sob o controle do STJ: o volume de entrada de processos. Entretanto, o STJ está elaborando propostas que visem minimizar os impactos externos. A partir de um anteprojeto elaborado pelo STJ, foi sancionada a lei $\mathrm{n}^{0} 11.636$, do dia 28 de dezembro de 2007, que dispões sobre a incidência de custas pela prestação de serviços forenses do Tribunal (que antes eram gratuitos), a ser regulamentada em 2008. Ademais, o Tribunal tem empenhado esforços para a aprovação de legislação processual que modernize e simplifique a tramitação dos feitos. Exemplo disso é a parceria feita com o Ministério da Justiça para aprovação do projeto de lei $\mathrm{n}^{\circ}$ 1213-B, de 2007, que estabelece procedimentos para o julgamento de recursos repetitivos no âmbito do STJ. (Fonte: Relatório de Gestão 
2007).

\subsection{2 - Objetivo Estratégico: acelerar o trâmite processual}

Meta 8: tramitar $80 \%$ dos recursos (agravo e recurso especial) em até 180 dias, até novembro/2005. A meta foi mantida para dezembro/2007.

a) Justificativa: Reduzir o tempo médio gasto em todas as fases de tramitação dos processos recursais, atendendo ao dispositivo constitucional que assegura a razoável duração do processo.

b) Indicador de eficiência: índice de processos recursais tramitados no prazo. Mede o percentual de processos recursais tramitados (desde o recebimento até a baixa) no prazo estabelecido.

c) Forma de apuração dos resultados: Somatório dos REsp e Ag. Baixados/arquivados (SRABP) no mês e tramitados em até 180 dias dividido pelo total dos REsp e Ag. Baixados/arquivados no mesmo período (SRAB) vezes 100. (*) $\underline{\text { SRABP x } 100}$ SRAB

(*) O tempo de tramitação considera a data do protocolo até a da baixa/arquivamento.

d) Resultados alcançados:

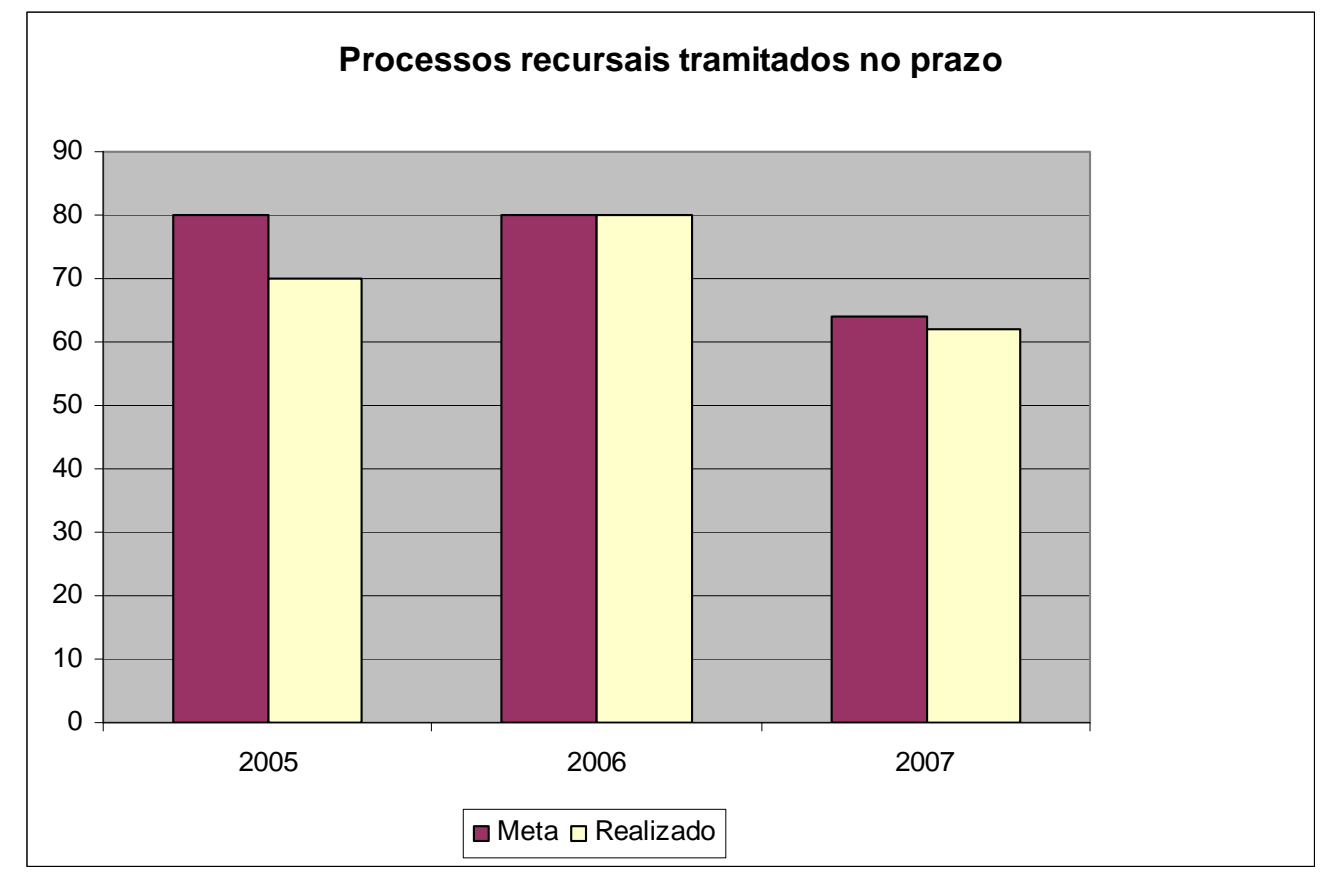

Gráfico 8 - Processos recursais tramitados no prazo.

Fonte: Relatórios de Gestão - Exercícios 2005, 2006 e 2007.

De acordo com os dados apresentados no gráfico em 2005, a meta não foi cumprida. Os dados estatísticos demonstram que atualmente a tramitação de $70 \%$ dos processos 
recursais está ocorrendo dentro do prazo estabelecido. A administração considerou que o resultado é positivo, visto que o índice encontra-se próximo à meta e apresenta uma melhoria de quase 20\% em relação ao dado inicial. (Fonte: Relatório de Gestão 2005).

Logo em 2006 a meta foi alcançada, considerando-se os processos distribuídos nos 12 meses do ano. Com o resultado favorável, decidiu-se que em 2007 o indicador passará a ser mensurado a partir do número de processos baixados no último ano (independentemente da data de protocolo) e será estabelecida nova meta. (Fonte: Relatório de Gestão 2006).

Foi definido como meta para 2007 tramitar pelo menos 64\% dos Agravos de Instrumento e Recursos Especiais (desde o protocolo até a baixa) em até 180 dias. Houve pequena alteração na forma de mensuração do indicador, em relação a 2006, com vistas a considerar toda a base de processos baixados que se encontra no Tribunal, e não apenas os distribuídos nos últimos 12 meses (cuja meta anterior de 80\% havia sido alcançada). O índice apurado demonstra que a meta ficou próxima ao esperado, com 62\% dos processos tramitando em até 180 dias. (Fonte: Relatório de Gestão 2007).

Acredita-se que a grande demanda seja o principal entrave ao alcance da meta estipulada. Além disso, alguns Ministros atuaram prioritariamente na eliminação de processos mais antigos, o que causa uma elevação no tempo. No projeto estratégico "otimização do trâmite processual” foi definida uma proporção ideal para julgamento de processos antigos recebidos há mais de um ano - e os processos mais recentes. Essas práticas já começaram ser adotadas por alguns Gabinetes de Ministro. (Fonte: Relatório de Gestão 2007).

Meta 9: tramitar os processos originários em 90 dias, em média, até novembro/2005. Meta mantida para 2006 e 2007.

a) Justificativa: reduzir o tempo médio gasto na tramitação dos processos originários, atendendo ao dispositivo constitucional que assegura a razoável duração do processo.

b) Indicador de eficiência: prazo médio de tramitação dos processos originários. Mede o prazo médio gasto entre a conclusão e a primeira decisão proferida nos processos originários.

c) Forma de apuração dos resultados: Somatório do Tempo de Tramitação de Processos Originários até a Primeira Decisão (STOPD) no mês, dividido pela quantidade de Processos Originários com a Primeira Decisão (POPD) no mês. (*) $\quad \underline{\text { STOPD }}$

POPD

(*) São consideradas para mensuração as classes AR, CC, HC, MC, MS e RCL, devido ao volume representativo. 
d) Resultados alcançados:

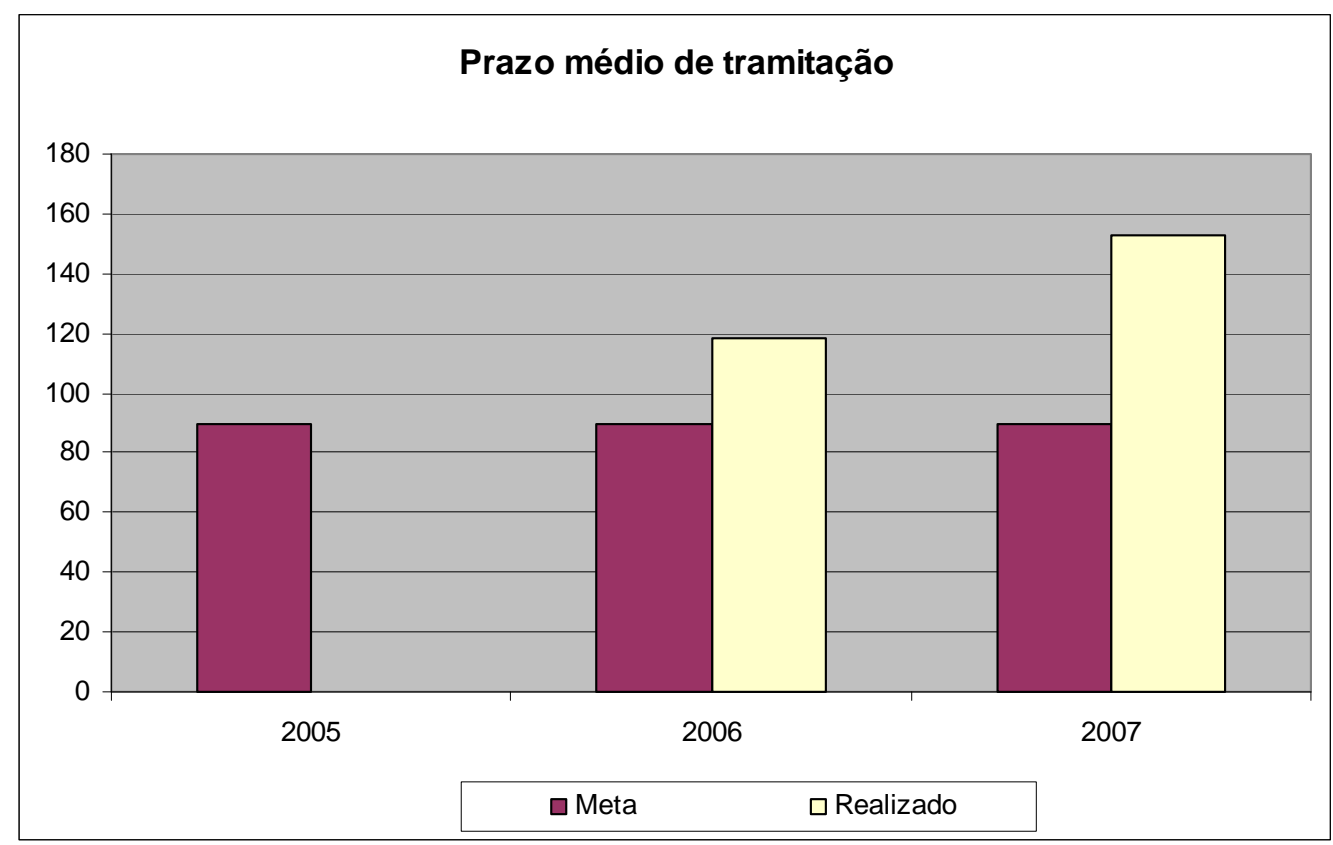

Gráfico 9 - Prazo médio de tramitação.

Fonte: Relatórios de Gestão - Exercícios 2006 e 2007.

Em 2005, a mensuração da meta foi prejudicada. O indicador e a meta serão revistos para 2006. A apuração desse indicador demanda um incremento nos procedimentos que permita mapear os prazos do processo fora do STJ (no Supremo Tribunal Federal e no Ministério Público). Como a atualização do referido procedimentos não foi implementada em 2005, pois depende inclusive de outros órgãos, ainda não foi possível mensurar o indicador de forma adequada. (Fonte: Relatório de Gestão 2005).

A meta de tramitar em média (desde o recebimento até a primeira decisão) no prazo de 90 dias todos os processos originários continuou em 2006. Observando o gráfico do ano de 2006, embora o prazo médio de tramitação tenha se situado acima do limite estabelecido, a evolução dos prazos mensais mostra uma trajetória decrescente. (Fonte: Relatório de Gestão 2006).

No ano de 2007 a meta não foi atingida e observou-se tendência de aumento nos prazos durante todo o ano. A explicação para o não cumprimento da meta foi o esforço em atuar nos processos mais antigos, aumentando dessa forma o tempo de tramitação. É importante destacar que à medida que ocorre a redução do volume de processos antigos, o prazo tende a retornar à trajetória de queda. (Fonte: Relatório de Gestão 2007).

\subsection{3 - Objetivo Estratégico: manter em patamares elevados o conceito do Tribunal}




\section{perante a sociedade.}

\section{Meta 10: Elevar para 63\% a percepção positiva da atuação do STJ, até dezembro/2007.}

a) Justificativa: garantir que a sociedade tenha uma boa imagem do Tribunal

b) Indicador de efetividade: percepção da atuação do STJ. Mede o percentual da população estudada que, em termos gerais, avalia positivamente a atuação do STJ.

c) Forma de apuração dos resultados: Número de Avaliações Positivas (AP) dividido pelo Total de Avaliações (TA), multiplicado por 100. $\quad \underline{\text { AP }}$ x 100

d) Resultados alcançados:

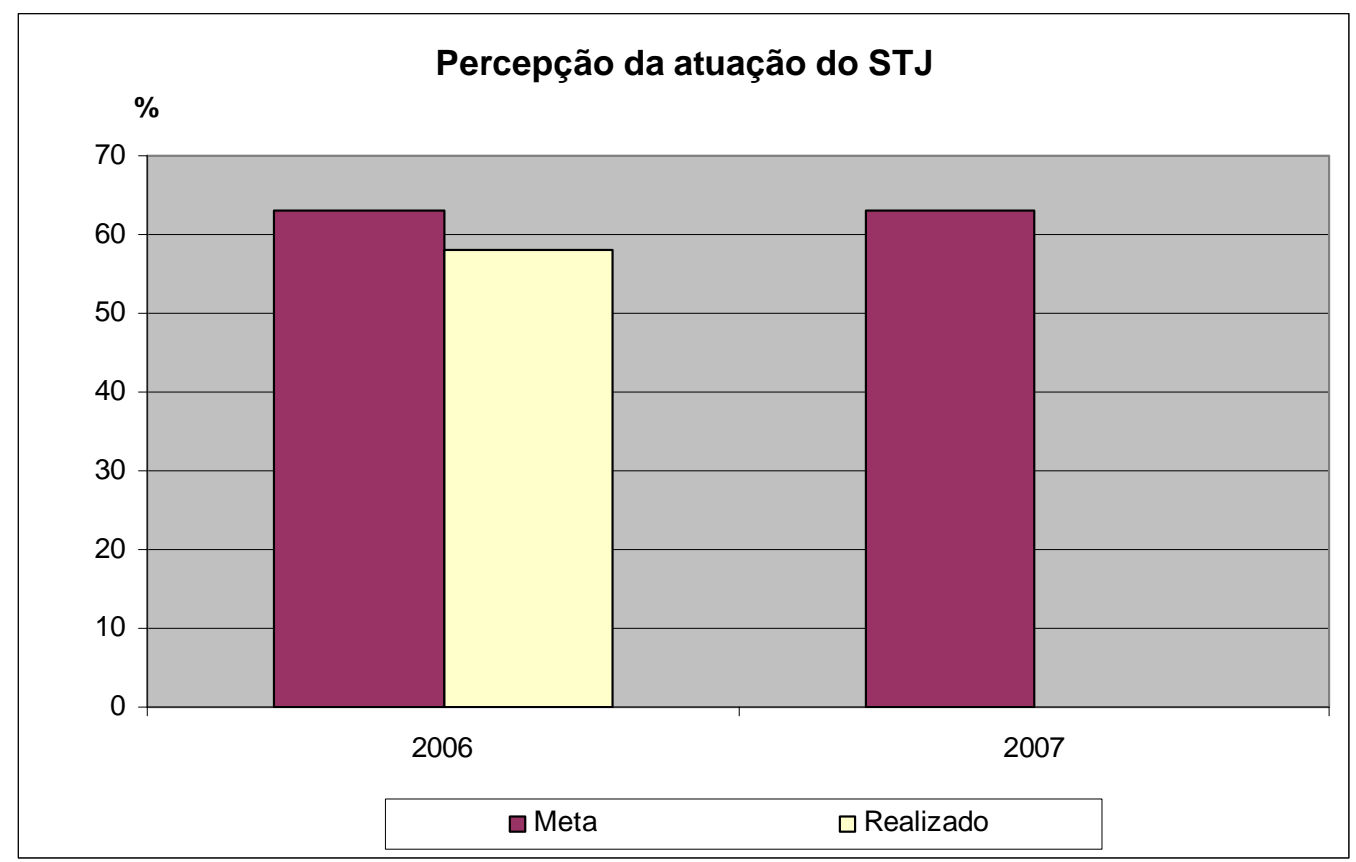

Gráfico 10 - Percepção da atuação do STJ.

Fonte: Relatórios de Gestão - Exercícios 2006 e 2007.

Foi realizada uma primeira pesquisa em março de 2006, para o levantamento da situação inicial. A amostra foi distribuída pelas cinco regiões do país. Verificou-se que 58\% dos entrevistados avaliam positivamente a atuação do STJ, patamar que se situou abaixo da meta estipulada, de 63\%. Entretanto, há que considerar a preocupação do STJ em atenuar os principais entraves de um sistema jurídico com problemas, cujo principal é a lentidão. Esses dados, além de reforçarem a preocupação do STJ em acelerar o trâmite processual, serviram de parâmetro para a definição das ações de comunicação a serem desenvolvidas para o alcance da meta no próximo ano. (Fonte: Relatório de Gestão 2006).

Em 2007 uma decisão administrativa definiu que a mensuração do indicador será bianual. Dessa forma, está em andamento a contratação de nova pesquisa, que será efetivada 
no primeiro semestre de 2008. (Fonte: Relatório de Gestão 2007).

\section{Meta 11: Elevar para 30\% o índice de conhecimento institucional até dezembro/2007}

a) Justificativa: garantir que a sociedade conheça e tenha uma boa imagem do Tribunal

b) Indicador de eficácia: nível de conhecimento institucional. Mede, em três índices, o percentual da população estudada que sabe da existência do STJ, conhece sua função e sabe dizer o que significa a sigla "STJ".

c) Forma de apuração dos resultados:

$$
\frac{\mathrm{N}^{\mathrm{o}} \text {. sabem da existência }}{\text { Total de respondentes }}+\frac{\mathrm{N}^{\mathrm{o}} \text {. conhecem função }}{\text { Total de respondentes }}+\frac{\mathrm{N}^{\mathrm{o}} \text {. conhecem sigla }}{\text { Total de respondentes }} \quad \mathrm{X} 100
$$

d) Resultados alcançados:

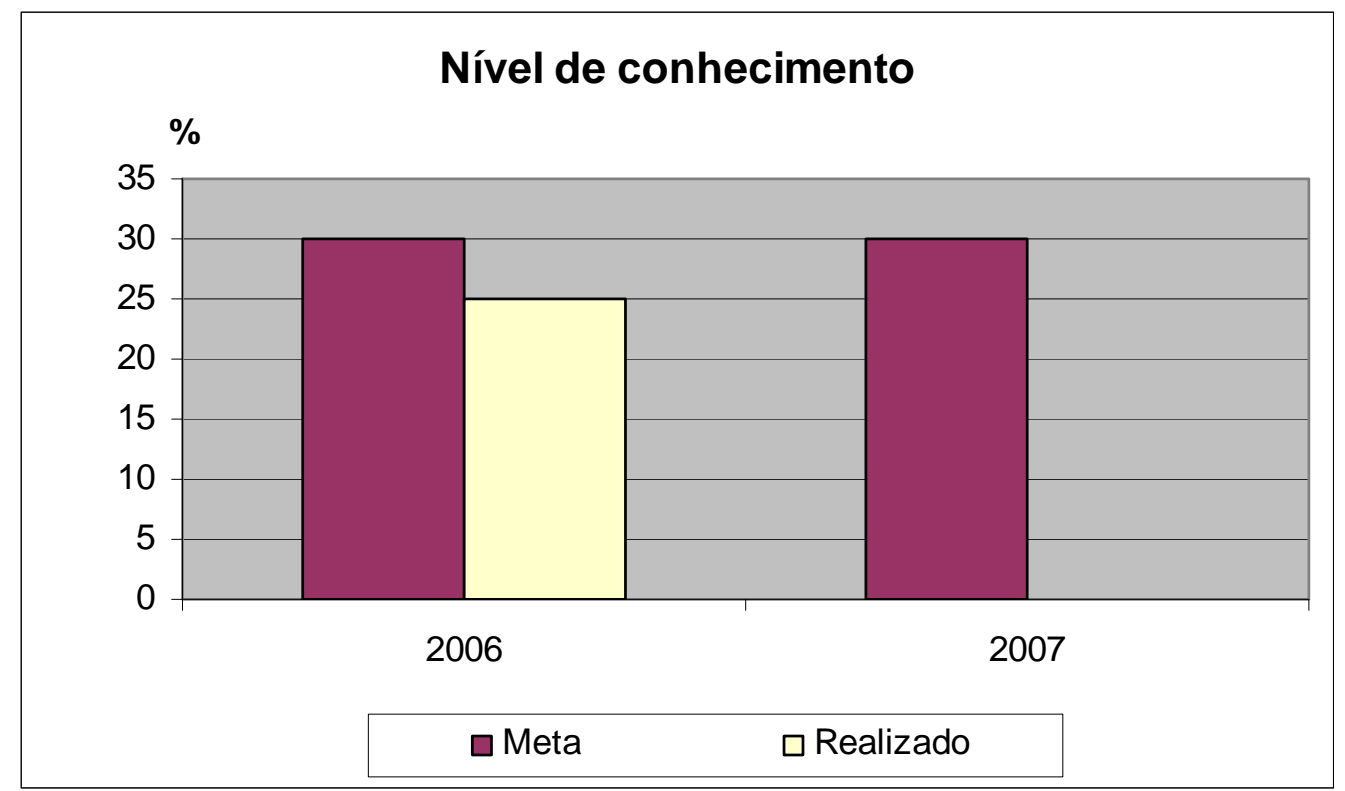

Gráfico 11 - Nível de conhecimento.

Fonte: Relatórios de Gestão - Exercícios 2006 e 2007

Com o intuito de demonstrar ao cidadão a função jurisdicional do STJ, foi traçada meta para elevar em 30\% o nível de conhecimento institucional até dezembro de 2007. Foi usada a mesma pesquisa da meta anterior, amostra distribuída nas cinco regiões do país. O resultado alcançado em 2006 foi o percentual de 25\% dos entrevistados conhecendo o STJ, 5 p.p. abaixo da meta estabelecida para dezembro/2007. O resultado mostrou que, para o grande público, o conhecimento sobre o STJ é difuso e em pouco difere da imagem do Judiciário como um todo. Dessa forma, é necessária uma maior divulgação junto à sociedade sobre as competências e atuação do Tribunal. (Fonte: Relatório de Gestão 2006). 
Em 2007 uma decisão administrativa definiu que a mensuração do indicador será bianual. Dessa forma, está em andamento a contratação de nova pesquisa, que será efetivada no primeiro semestre de 2008. (Fonte: Relatório de Gestão 2007). 


\section{3 - Análise das metas e resultados relativos à Perspectiva 3 - Aprendizado e crescimento}

Essa perspectiva tem como foco o investimento nas pessoas e na infra-estrutura. Abrange os objetivos estratégicos de contribuir para a modernização do Judiciário; desenvolver competências; e melhorar o clima organizacional.

\subsection{1 - Objetivo Estratégico: contribuir para modernização do judiciário}

Meta 12: Integrar as informações processuais de pelo menos oito organizações com o STJ até dezembro/2007

a) Justificativa: melhorar a comunicação entre as diversas organizações e o STJ e evitar retrabalho nas atividades de apoio ao julgamento.

b) Indicador de eficácia: número de organizações integradas. Mede o número de organizações cujos dados processuais estejam integrados com o STJ.

c) Forma de apuração dos resultados: Somatório de organizações integradas no período

d) Resultados alcançados:

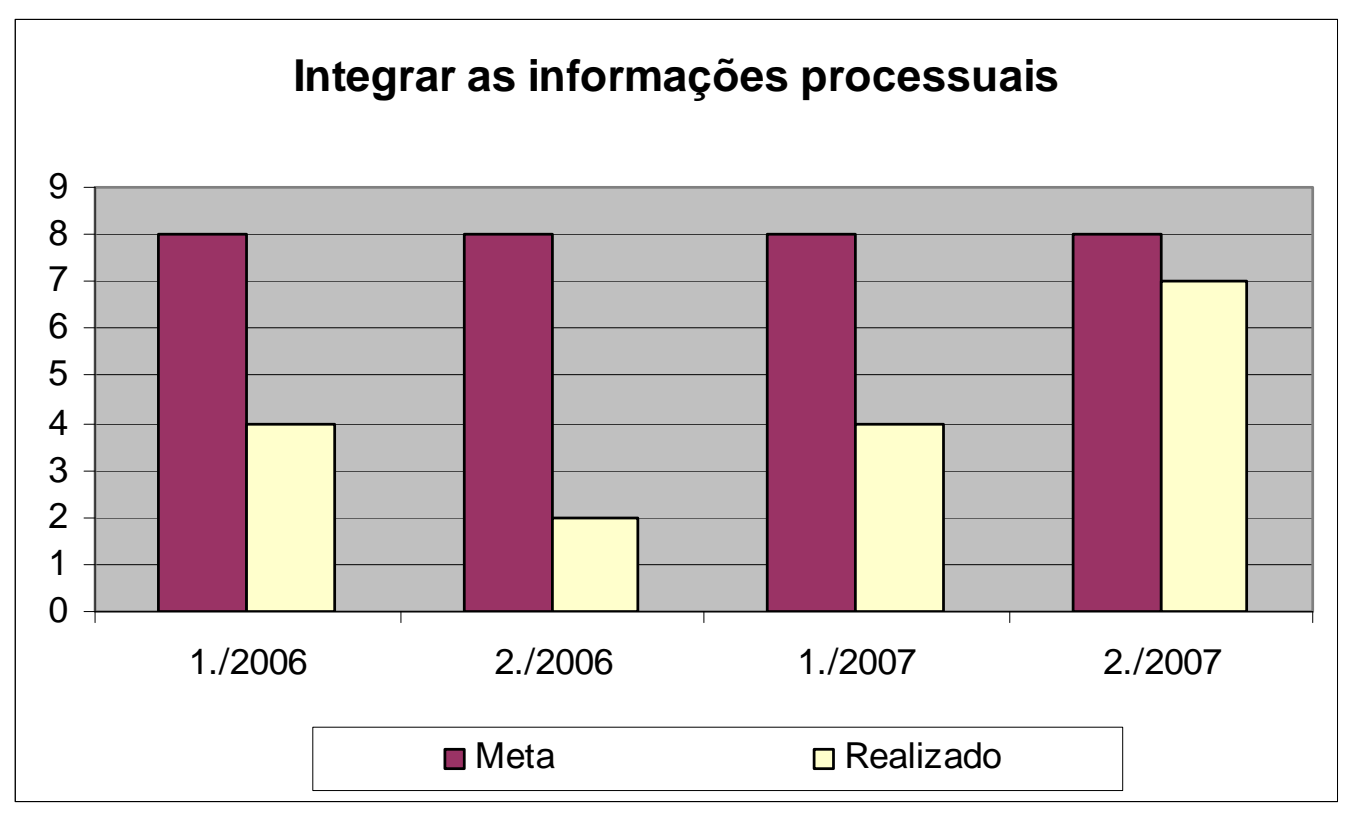

Gráfico 12 - Integrar as informações processuais.

Fonte: Relatórios de Gestão - Exercícios 2006 e 2007.

A meta estabelecida foi integrar as informações processuais de pelo menos oito organizações com o STJ, até dezembro de 2007. No intuito principalmente de diminuir o retrabalho no processamento inicial e agilizar o trâmite dos julgamentos. No início de 2006 houve a integração tecnológica do STJ com quatro tribunais: TRF1, TRF2, TRF4 E TJ-RS. 
(Fonte: Relatório de Gestão - exercício 2006).

Em 2006 a meta não foi cumprida. Após alguns problemas de falta de atualização por parte dos Tribunais e de instabilidade no sistema, foram realizados os devidos ajustes e, em dezembro de 2006, apenas o TRF4 e o TJ-RS estavam em pleno funcionamento. Cabe ressaltar que o TJ-RS é o responsável pelo maior volume de processos remetidos ao STJ. O STJ já está em vias de restabelecer a interligação com o TRF2 e TRF1 e de firmar convênio com outros tribunais, como o TJ-SE (Fonte: Relatório de Gestão - exercício 2006).

Em 2007 a meta não foi cumprida. O STJ estabeleceu contatos no sentido de manter e integrar mais tribunais e o resultado apresentado ficou próximo do esperado, visto que seis tribunais apresentam suas bases de dados plenamente integradas ao STJ: TRF-1, TRF-2, TRF4, TJ-DFT, TJ-RS e TJ-SE, tendo sido, ainda, firmado acordo de cooperação técnica com o TJ-ES, no final do ano. Estão em andamento contatos com o TRF-5 e TJ-SP, com vistas a viabilizar a integração dentro da maior brevidade possível. (Fonte: Relatório de Gestão exercício 2007).

As dificuldades apresentadas para o alcance da meta podem ser atribuídas à disponibilidade e interesse dos Tribunais para adoção dos procedimentos de integração apresentados pelo STJ. (Fonte: Relatório de Gestão - exercício 2007).

Meta 13: Garantir apreciação nas comissões de $80 \%$ dos projetos de lei de interesse do STJ no Congresso Nacional, até dezembro/2007.

a) Justificativa: assegurar a implementação das inovações legislativas necessárias ao bom funcionamento do sistema judiciário.

b) Indicador de eficácia: índice de apreciação dos Projetos de Lei. Mede o percentual de Projetos de Lei de interesse do STJ apreciados nas diversas Comissões do Congresso Nacional e que receberam parecer definitivo, em relação ao total de Projetos de Lei de interesse do STJ.

c) Forma de apuração dos resultados: Projetos de Lei Apreciados com Parecer Definitivo da última comissão (PLAPD) a partir de Abril/2006 dividido pelo total de Projetos de Lei de Interesse do STJ (PLISTJ) do mês anterior, vezes 100. $\underline{\text { PLAPD } \times 100}$

\section{PLISTJ}

d) Resultados alcançados (ver gráfico na página seguinte):

O indicador foi estabelecido para acompanhar a atuação do STJ junto ao Poder Legislativo a fim de garantir aprovação das leis que visam otimização/modernização do Judiciário, e em especial do STJ. Em 2006, a meta não foi alcançada, mas, foram priorizados 


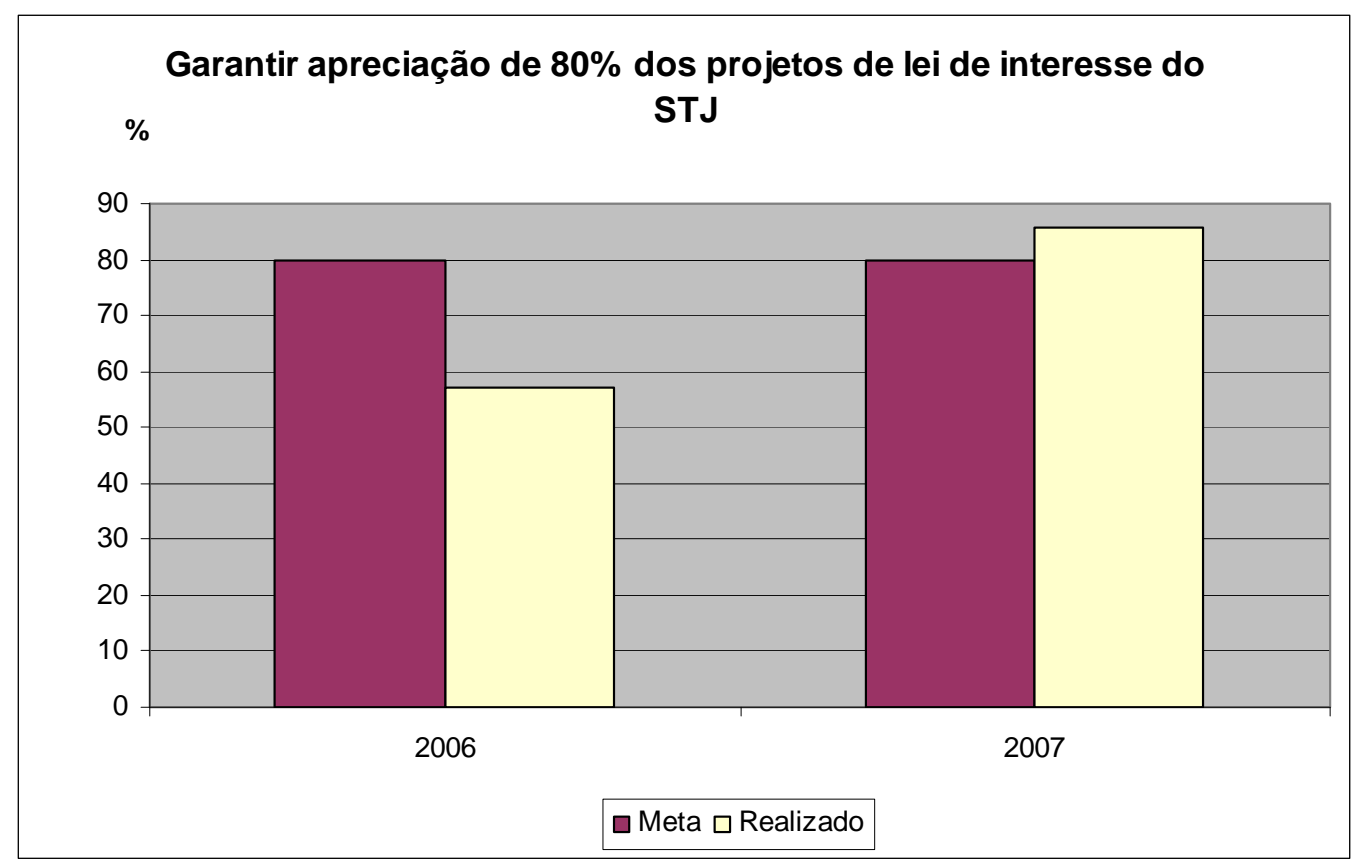

Gráfico 13 - Garantir a apreciação de 80\% dos projetos de lei de interesse do STJ.

Fonte: Relatórios de Gestão - Exercícios 2006 e 2007

sete projetos de lei, cuja tramitação começou a ser acompanhada desde maio de 2006. Entre eles estavam a Reforma do Judiciário, a Criação das 230 Novas Varas, o Plano de Cargos e Salários, o Projeto de Lei que cria às custas judiciais no STJ e as Lei do Orçamento. Os resultados alcançados em 2006 referem-se à aprovação da Lei de Diretrizes Orçamentárias e Lei Orçamentária Anual de 2007, e do Projeto de Lei que tratou dos Cargos e Salários dos Servidores do Poder Judiciário. (Fonte: Relatório de Gestão - exercício 2006).

Em 2007 a meta foi alcançada, pois dos sete projetos de lei, cuja tramitação começou em 2006. Entre eles estão a Reforma do Judiciário, o Plano de Cargos e Salários, o Projeto de Lei que criou às custas judiciais no STJ e as Leis do Orçamento, todos foram devidamente aprovados. Apenas o Projeto de Lei referente à criação das novas Varas Federais, ainda não passou pelo plenário da Câmara dos Deputados. (Fonte: Relatório de Gestão - exercício 2007).

\subsection{2 - Objetivo Estratégico: Desenvolver Competências}

Meta 14: Convergir $100 \%$ dos processos e instrumentos aplicados no desenvolvimento de pessoas para o modelo por competências, até dezembro/2007.

a) Justificativa: acompanhar a modernização da gestão de pessoas, contribuindo para uma boa atuação funcional, assegurando a melhoria do desempenho funcional.

b) Indicador de eficácia: Índice de conversão para o modelo por competências. Mede o 
percentual de processos e instrumentos utilizados na área de desenvolvimento de pessoas consoantes ao modelo definido como sendo por competências.

c) Forma de apuração dos resultados: Somatório de Processos e Instrumentos de Gestão de Pessoas por Competências (PIGPC), dividido pelo somatório de Processos e Instrumentos Aplicados no Desenvolvimento de Pessoas (PIADP), multiplicado por 100.

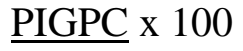 \\ PIADP}

d) Resultados alcançados:

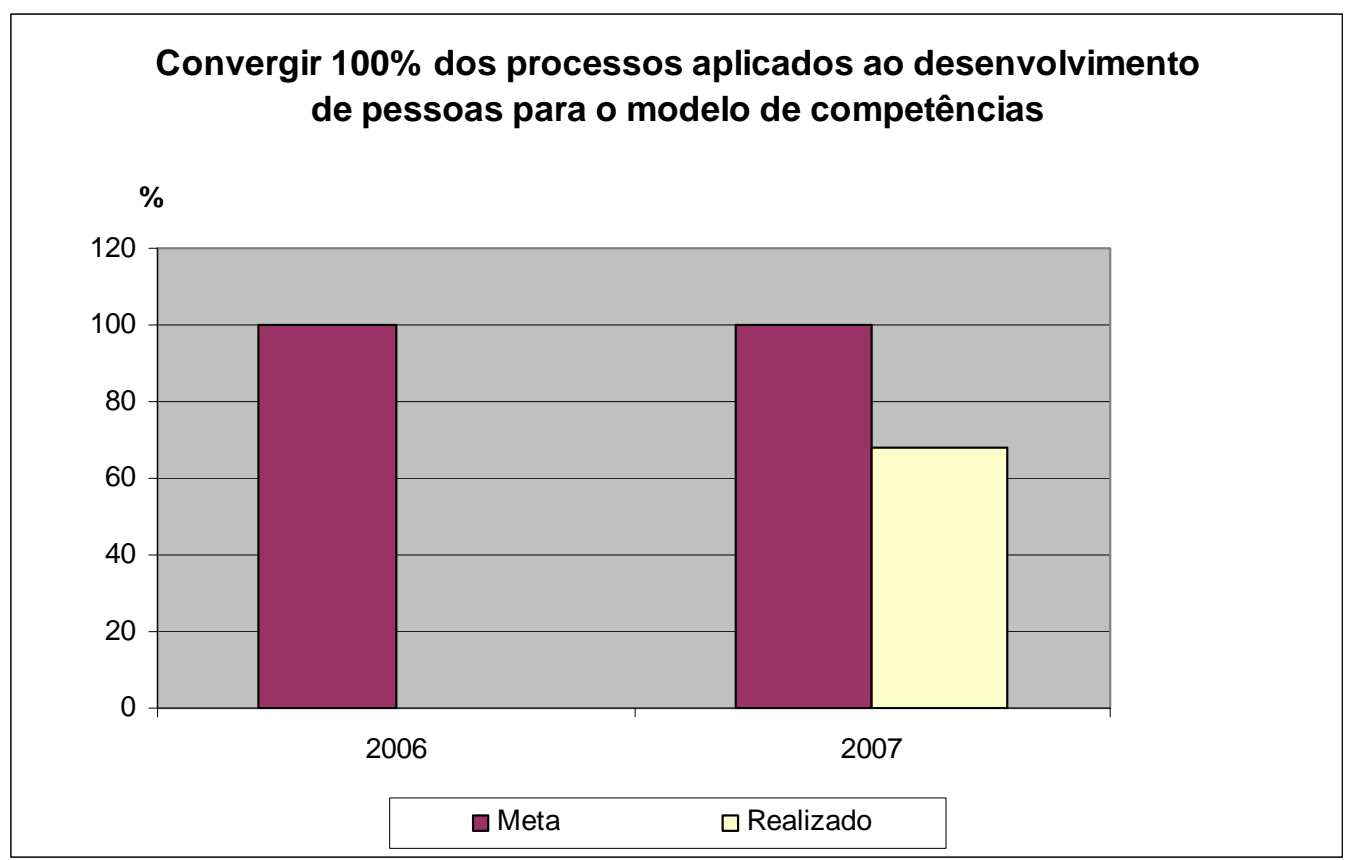

Gráfico 14 - Convergir 100\% dos processos aplicados ao desenvolvimento de pessoas para o modelo de competências.

Fonte: Relatórios de Gestão - Exercícios 2006 e 2007.

Em 2006, foi elaborado o planejamento das mudanças necessárias, conforme cronograma estabelecido, e em 2007 os processos e instrumentos começaram a ser convertidos para o modelo por competências. Assim, o índice em 2006 ainda está em zero, porém, com previsão de alcance da meta no prazo proposto. (Fonte: Relatório de Gestão exercício 2006).

As atividades realizadas durante o ano de 2007 alcançaram o índice de 68\% de conversão dos processos e instrumentos para o modelo por competências. O principal motivo do não cumprimento da meta foi a dificuldade de integração da solução Efix (software adquirido pelo STJ para implantar a gestão por competências) com os sistemas existentes no STJ, o que atrasou o cronograma. Vale ressaltar também que as atividades necessárias à 
realização do treinamento dos gestores/avaliadores no novo modelo foram subestimadas e seu replanejamento teve influência no cronograma de implantação. (Fonte: Relatório de Gestão exercício 2007).

Meta 15: Treinar 20h/servidor, em média, por ano. A meta em 2006 foi revista para 30h e em 2007 para 40h em média.

a) Justificativa: Aperfeiçoar a execução das atividades do Tribunal, assegurando oportunidades constantes de treinamento aos servidores.

b) Indicador de eficácia: Média de horas de treinamento por servidor. Mede a quantidade média de horas de treinamento por servidor no período.

c) Forma de apuração dos resultados: Somatório de Horas de Treinamento Realizadas no Ano (HTRA), dividido pelo Total de Servidores (TS) * $\underline{\text { HTRA }}$

TS

* Entende-se como Total de Servidores a lotação verificada no último dia do mês.

d) Resultados alcançados:

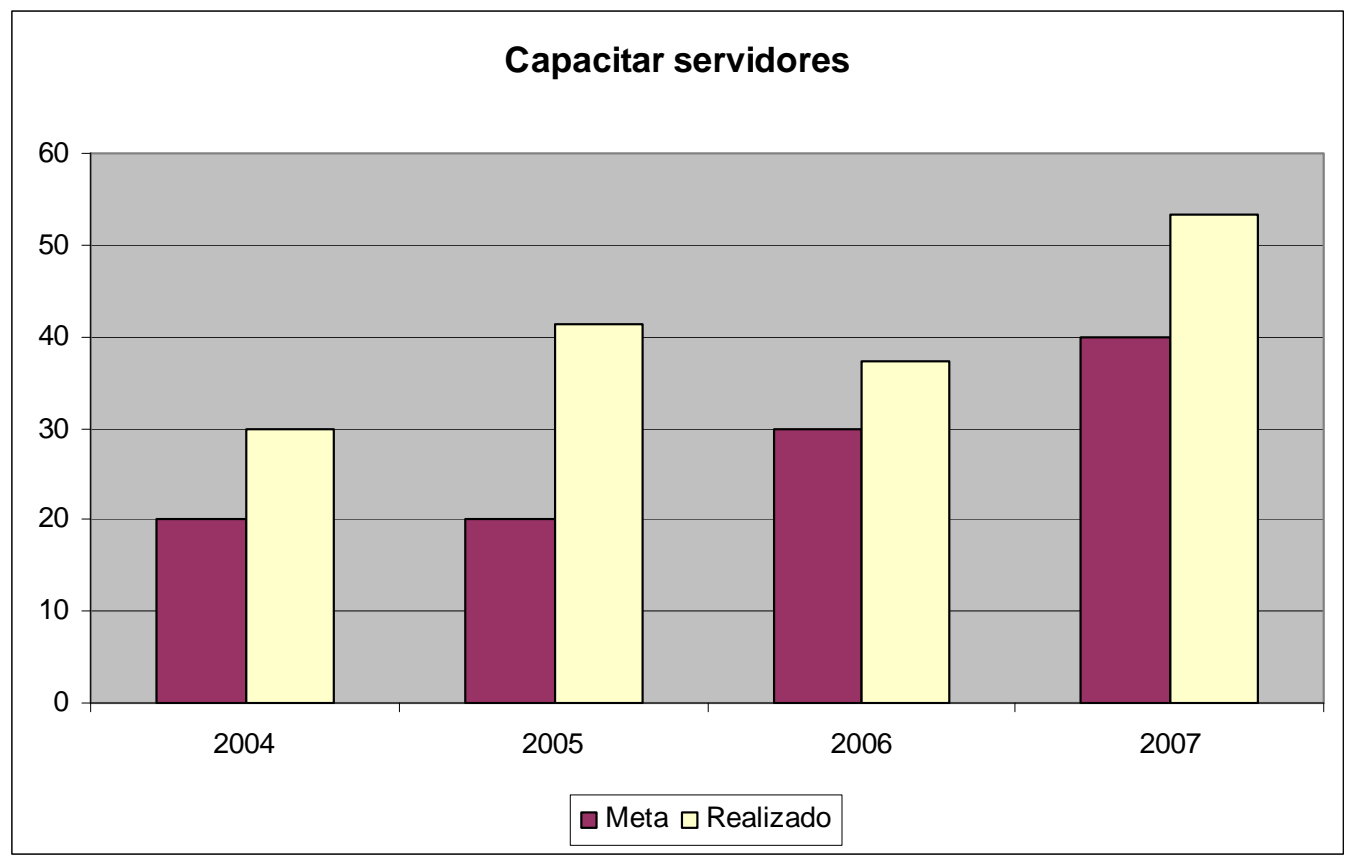

Gráfico 15 - Capacitação de servidores.

Fonte: Relatórios de Gestão - Exercícios 2005, 2006 e 2007.

Foram cumpridas as metas em todos os anos. Em 2004, foram realizadas 30 horas (aproximadamente) de treinamento por servidor, e em 2005 essa média alcançou 41 horas, o que representou um total de mais de 104.000 horas de treinamento. Devido aos bons resultados, essa meta foi revista para 2006, com o fim de renovar seu caráter desafiador. 
(Fonte: Relatório de Gestão - exercício 2005).

A nova meta definida foi treinar 30h/servidor, em média, por ano. A meta foi alcançada antes do prazo previsto, consolidando os bons resultados apresentados também em 2004 e 2005. (Fonte: Relatório de Gestão - exercício 2006).

Para 2007 a meta foi revista para treinar 40h/servidor, em média. A meta foi alcançada em outubro, perfazendo um total de mais de 140 mil horas de treinamento ao final do ano. A intenção da Secretaria de Gestão de Pessoas, responsável pela meta, é definir meta individualizada para treinamento em 2008, proporcionando otimização da performance de seus colaboradores. (Fonte: Relatório de Gestão - exercício 2007).

\subsection{3 - Objetivo Estratégico: melhorar o clima organizacional}

Meta 16: Obter $80 \%$ de satisfação do servidor, na pesquisa de clima organizacional até novembro/2005. A meta foi mantida no plano de gestão 2006 - 2008.

a) Justificativa: alcançar a excelência no nível de satisfação dos servidores com as condições de trabalho na organização.

b) Indicador de efetividade: índice de satisfação do servidor. Mede o grau de satisfação dos servidores com o STJ, considerando: gestão de processos, recursos e condições ambientais, comunicação interna, liderança, motivação, visão sistêmica e relacionamento.

c) Forma de apuração dos resultados: Pesquisa de Clima Organizacional

d) Resultados alcançados constantes do gráfico da página seguinte:

Conforme gráfico da página seguinte, o índice de satisfação do servidor alcançado em 2004 foi de 75\%, 5\% p.p. abaixo da meta proposta. (Fonte: Relatório de Gestão - exercício 2005). Em outubro/2005 foi realizada uma nova pesquisa de clima organizacional e o índice de servidores satisfeitos com o STJ foi de 70\%. Em resposta a queda no índice (75\% para 70\%) foi criado um comitê gestor do clima, que se reúne mensalmente para alavancar diversas ações de melhoria nos fatores de comunicação, gestão de processos, liderança, condições ambientais, relacionamento e motivação. O comitê decidiu que a realização da pesquisa deveria ser bianual. (Fonte: Relatório de Gestão - exercício 2005).

Em 2007, foi realizada pesquisa, com o apoio da Revista Exame/Você SA e da FIA/USP, onde o STJ concorreu as 150 melhores empresas para se trabalhar. Sendo o STJ a única organização pública pré-classificada pela Revista. O resultado da pesquisa atingiu 78,8\% apresentando melhoria e ficando bem próximo da meta almejada. 


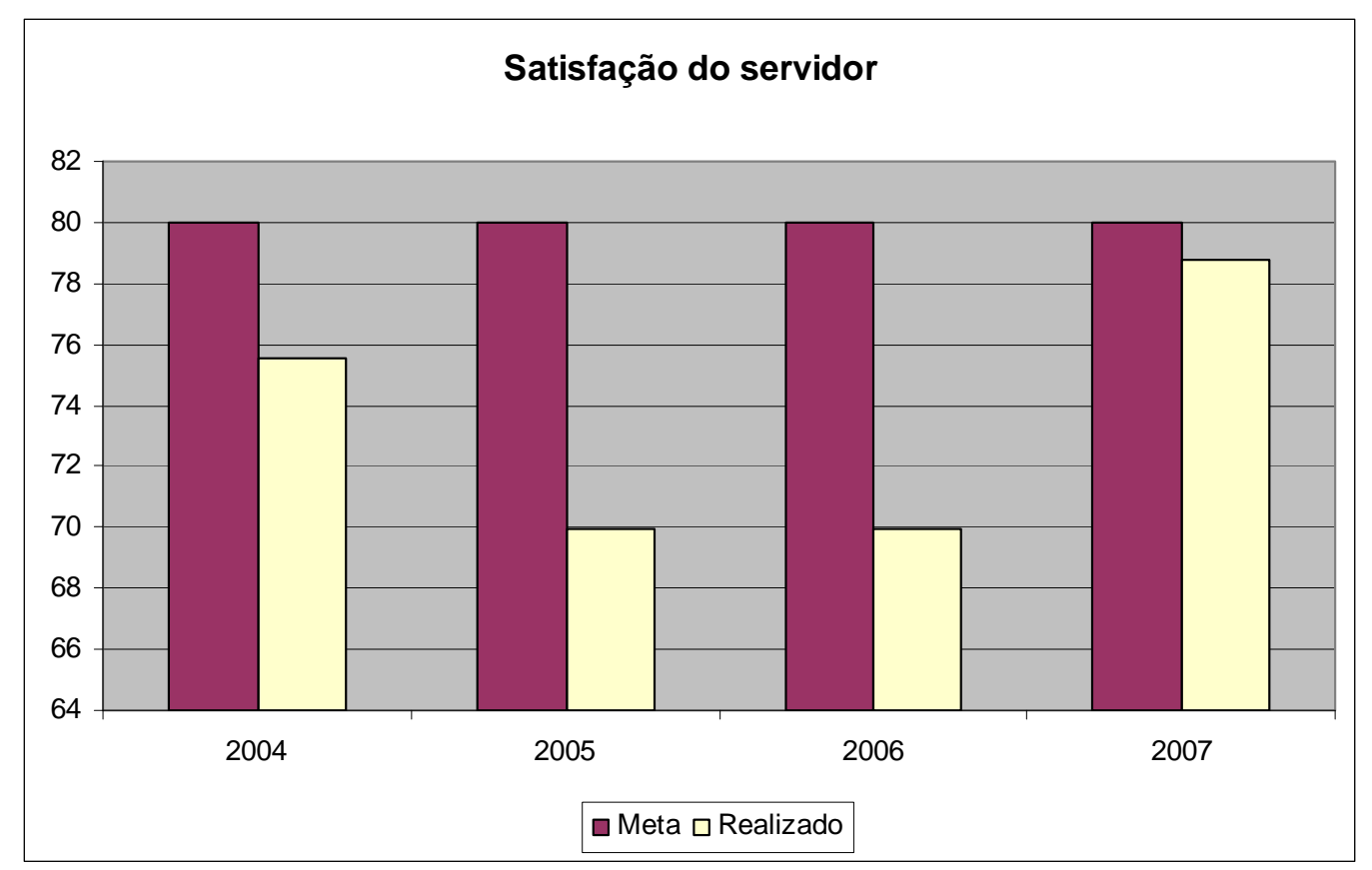

Gráfico 16 - Satisfação do servidor.

Fonte: Relatórios de Gestão - Exercícios 2005, 2006 e 2007

A pesquisa também serviu para explicitar onde o Tribunal precisa investir para melhorar a relação com seus colaboradores. O comitê gestor do clima passará a conduzir ações que promovam oportunidades de inovação, fortalecimento da liderança e desenvolvimento na carreira. (Fonte: Relatório de Gestão - exercício 2007). 


\section{4 - Análise das metas e resultados relativos à Perspectiva 4 - Orçamento}

Refere-se à viabilização da disponibilidade financeira indispensável ao cumprimento das metas institucionais. Para esta perspectiva foi definido apenas o objetivo de assegurar e gerir os recursos orçamentários e financeiros.

\subsection{1 - Objetivo Estratégico: Assegurar e gerir os Recursos Orçamentários e Financeiros}

Meta 17: Em 2004, a meta estabelecida foi economizar, até o final do exercício, de 3\% na renovação dos contratos de serviços continuados. No plano de gestão 2006/2008 passou a ser: economizar, até o final do exercício, $3 \%$ na utilização dos recursos orçamentários.

a) Justificativa: economizar na utilização dos recursos, permitindo reaplicação em ações de impacto estratégico.

b) Indicador de eficiência: índice de otimização de recursos orçamentários. Mede a economia de recursos orçamentários utilizados pelo STJ.

c) Forma de apuração dos resultados:

100 - Recursos estimados para contratos c/ reajuste máximo - (Valor negociado) x 100

Recursos estimados para contratos c/ reajuste máximo

Recursos estimados: previsão inicial da despesa com contratos de prestação continuada com reajuste máximo previsto para o período/Valor negociado: Consecução de abatimento junto à empresa no percentual do índice de reajuste do contrato a ser aplicado no período.

d) Resultados alcançados:

Conforme demonstrado no gráfico na página seguinte, em 2004 a meta foi superada, chegando a economia a 5,49\% superando a meta em 2,49\% p.p. (Fonte: Relatório de Gestão exercício 2005).

O índice apurado em dezembro/2005 foi de 2.03\%, o que representa um total de R\$ 511.133,15 economizados. Com esse percentual a meta de economizar 3\% não foi cumprida. Vale mencionar que a deflação no IGP-DI/FGV (índice utilizado como parâmetro para a renovação dos contratos), em 2005, impactou diretamente no indicador em questão, puxando pra baixo o índice de otimização dos recursos financeiros. (Fonte: Relatório de Gestão exercício 2005). 


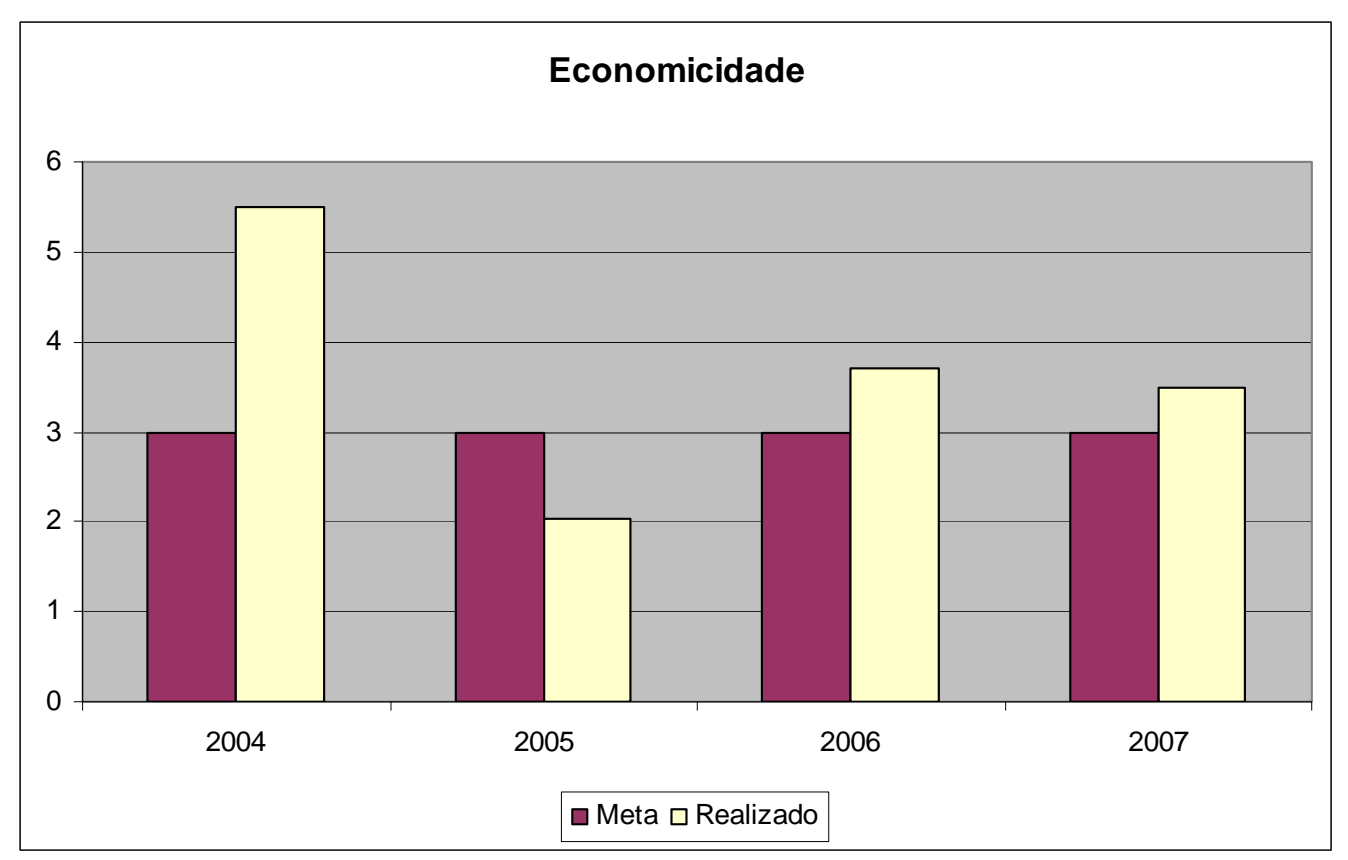

Gráfico 17 - Economicidade.

Fonte: Relatórios de Gestão - Exercícios 2005, 2006 e 2007.

Em 2006, a meta foi atingida, economizando R \$905.000,00 durante o ano, chegando a 3,7\% de economia. (Fonte: Relatório de Gestão - exercício 2006).

Em 2007, a meta também foi atingida, com uma economia de mais de R $272.000,00$, chegando a 3,49\% de economia. (Fonte: Relatório de Gestão - exercício 2007).

Meta 18: Alcançar 99\% de aplicação dos recursos orçamentários ao final do exercício. No plano de gestão 2006/2008 houve alteração no percentual passando a meta para $100 \%$ de aplicação dos recursos.

a) Justificativa: assegurar a eficiência da organização na aplicação dos recursos consignados ao tribunal no orçamento geral da união.

b) Indicador de eficiência: índice de aplicação dos recursos orçamentários. Mede o percentual da execução orçamentária em relação ao orçamento aprovado na Lei Orçamentária Anual LOA, acrescido dos créditos suplementares.

c) Forma de apuração dos resultados: Para assegurar a eficiência da organização na aplicação dos recursos consignados ao Tribunal no Orçamento Geral da União.

d) Resultados alcançados demonstrado no gráfico da página seguinte: 


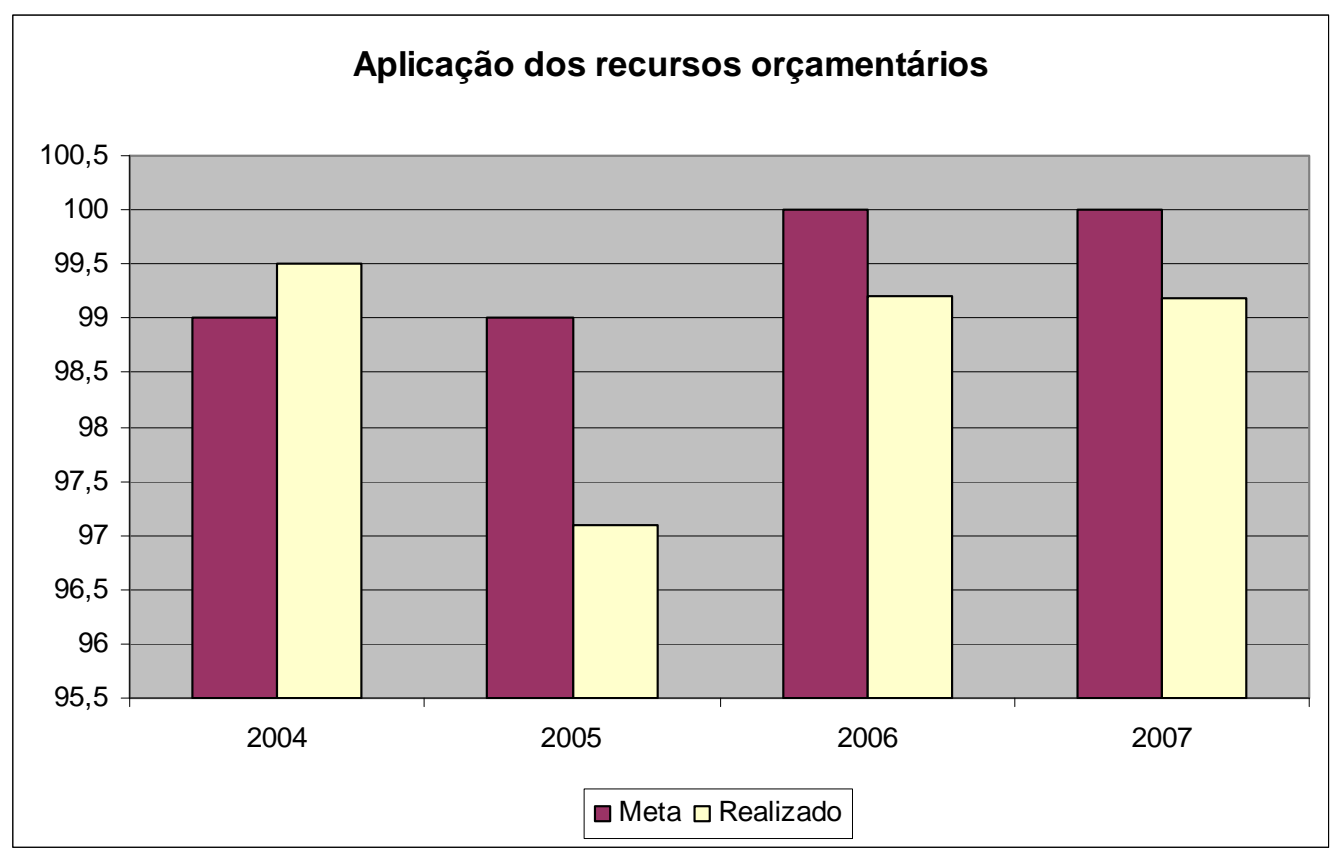

Gráfico 18 - Aplicação dos recursos orçamentários.

Fonte: Relatórios de Gestão - Exercícios 2005, 2006 e 2007.

Em 2004 a meta foi cumprida, alcançando o índice de 99,5 de aplicação do orçamento no exercício. (Fonte: Relatório de Gestão - exercício 2005).

A execução orçamentária em 2005 foi de 90,66\%, abaixo da meta estabelecida de 99\%. Isso ocorreu por conta do contingenciamento de crédito efetuado na ação Implantação de Sistema Integrado de Gestão, no valor de R \$ 51.599.0000,00. Essa quantia permaneceu contingenciada durante quase todo o exercício, tendo sido liberados $\mathrm{R} \$ 11.219 .392,00$ no final de dezembro (Atos $n^{0}$ 294, de 26/12/2005 e 296, de 29/12/2005), quando não foi mais possível utilizá-los. Considerando o percentual da despesa realizada $(90,66 \%)$ mais o total contingenciado (6,53\%), a execução do orçamento chega a 97,19\%, conforme demonstrado no gráfico acima. (Fonte: Relatório de Gestão - exercício 2005).

No ano de 2006, a execução apurada foi de 99,21\%, abaixo da meta estabelecida de 100\%. (Fonte: Relatório de Gestão - exercício 2006).

Já em 2007 apurou-se 99,18\% de execução, percentual bem próximo da meta estabelecida de 100\%, mostrando que quase a totalidade dos recursos foram aplicados conforme planejado, demonstrando eficiência na utilização do dinheiro público. (Fonte: Relatório de Gestão - exercício 2007).

Meta 19: Obter 5\% de incremento de recursos para investimentos entre os exercícios financeiros.

a) Justificativa: garantir o incremento constante nos recursos orçamentários destinados a 
investimentos a fim de atender às demandas de melhoria.

b) Indicador de eficácia: índice de incremento de recursos para investimentos. Mede o percentual de incremento de recursos para investimentos com ações estratégicas em relação ao exercício anterior.

c) Forma de apuração dos resultados:

\section{(Total destinado a investimentos no ano atual -1) x 100}

Total destinado a investimentos no ano anterior

d) Resultados alcançados:

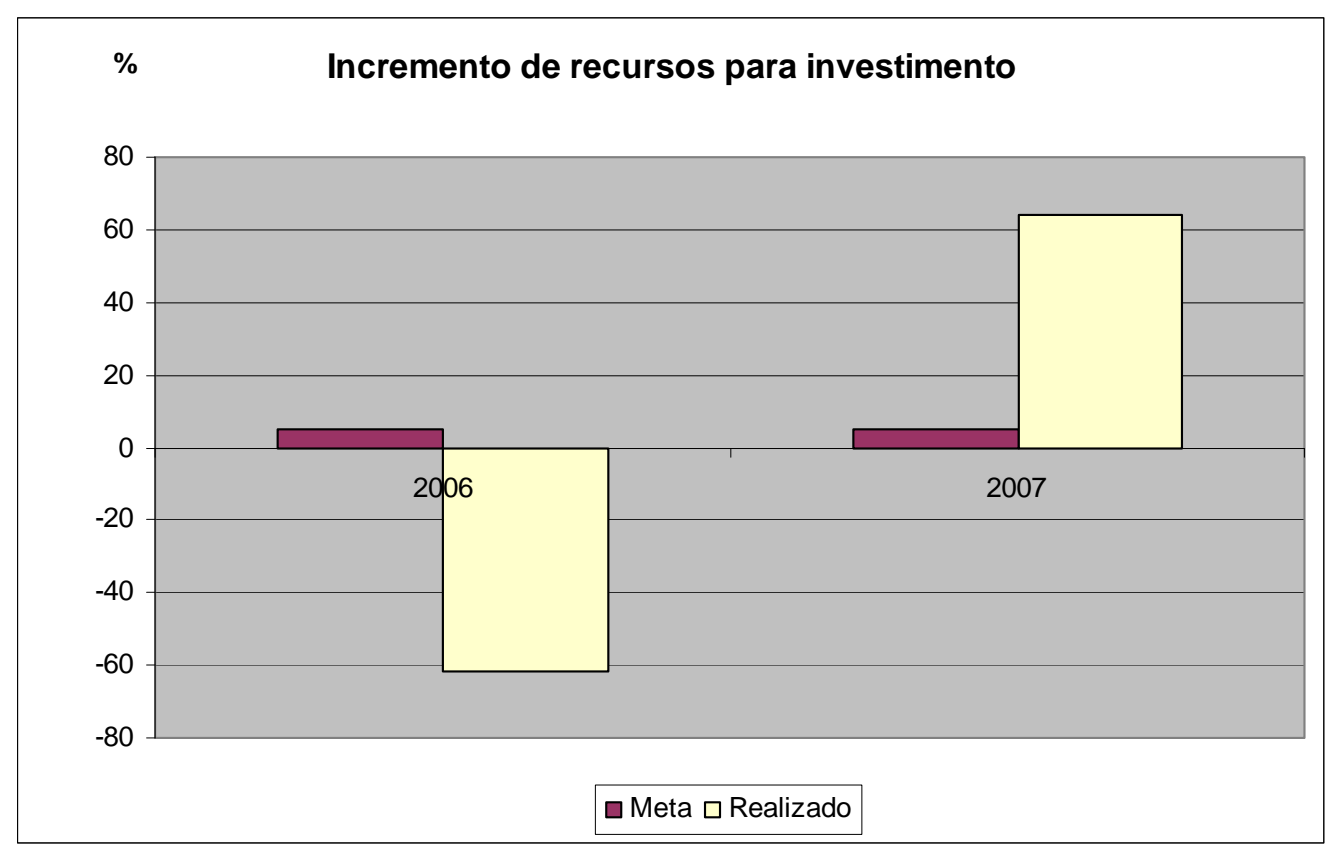

Gráfico 19 - Incremento de recursos para investimento.

Fonte: Relatórios de Gestão - Exercícios 2006 e 2007.

A meta foi proposta em 2005 e o incremento só foi mensurado nos exercícios financeiros seguintes, quando foi possível a comparação. O investimento em 2005 foi de R\$ 3.454.440,00. (Fonte: Plano de Gestão - 2006 - 2008).

Em 2006 foram reservados R\$ 7.073.060,25 para a implementação de projetos considerados estratégicos para a gestão. A baixa execução financeira dos projetos nesse primeiro período da gestão impactou negativamente o alcance da meta. A implementação do Escritório Corporativo de Projetos do STJ, efetivado no primeiro semestre de 2007, foi o primeiro passo para a correção das distorções relacionadas ao controle orçamentário dos projetos, uma vez que o mesmo atuará no treinamento e conscientização dos gestores de projeto e no controle mais efetivo do andamento das atividades. (Fonte: Relatório de Gestão exercício 2006). 
Em 2007, foram gastos $\mathrm{R} \$ 2.160 .842,26$ com a implementação de projetos considerados estratégicos para a gestão, resultando em incremento de 64\%. Diante dos resultados alcançados já está prevista a mudança do indicador para mensurar a disponibilidade do orçamento requerido para implantação dos projetos, ao invés do seu acréscimo de um ano para o outro. (Fonte: Relatório de Gestão - exercício 2007).

\section{Meta 20: Diminuir em 10\% o custo do processo judicial, até dezembro/2007.}

a) Justificativa: Reduzir o custo administrativo do tribunal, aumentando a produtividade e dando maior retorno à sociedade pelo cumprimento eficiente da função jurisdicional do STJ.

b) Indicador de eficiência: custo do processo judicial no STJ. O valor do custo é calculado pela divisão entre o orçamento anual executado e o número de julgados no ano. Mede o valor médio gasto com os processos judiciais, relacionando o orçamento aplicado do tribunal ao total de julgados no período.

c) Forma de apuração dos resultados:
Orçamento anual aplicado do STJ
Total de julgados no ano
d) Resultados alcançados:

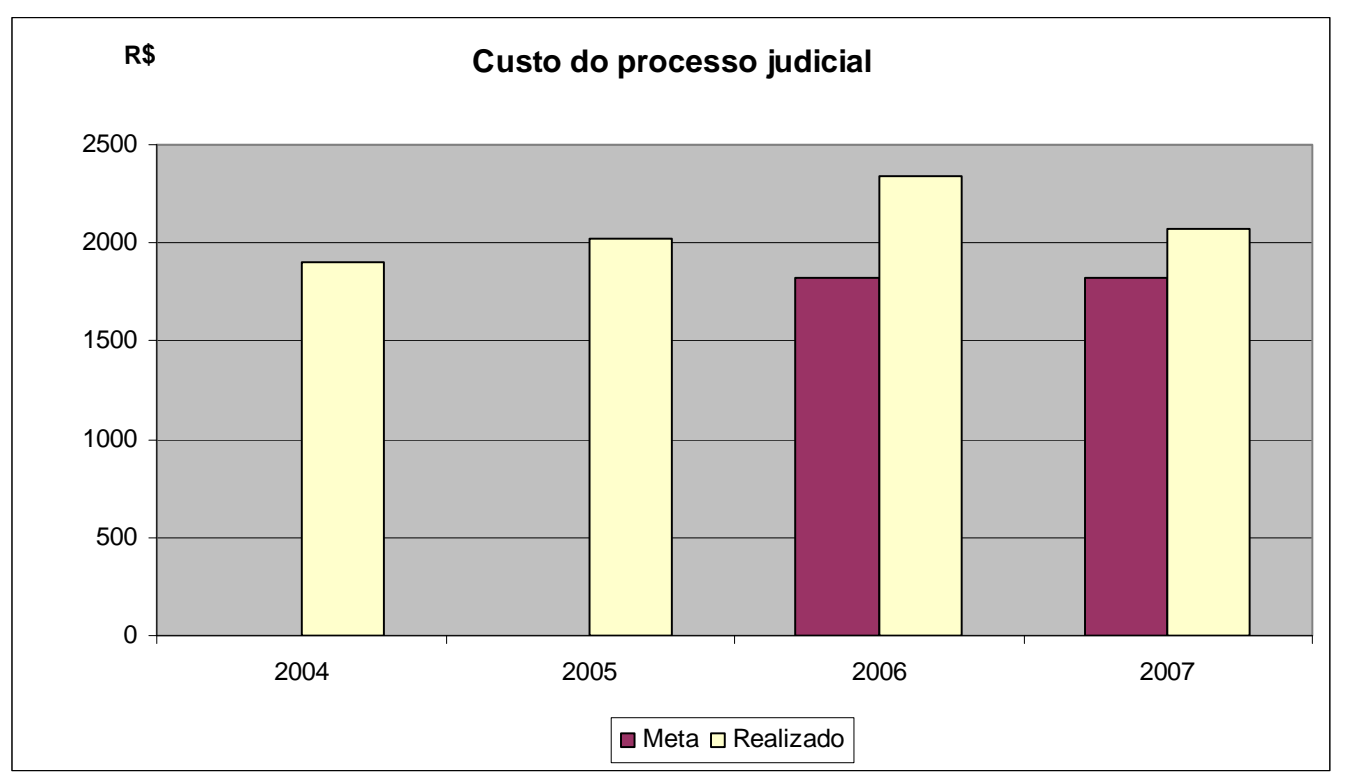

Gráfico 20 - Custo do processo judicial.

Fonte: Relatórios de Gestão - Exercícios 2005, 2006 e 2007.

A meta não foi atingida em 2006. O resultado aferido foi aquém do valor esperado, chegando a R\$2.344,03 o custo unitário do processo, valor superior a meta estabelecida de R\$ 1.820,58. Entretanto, a implementação do projeto Avaliação de Custos, em 2007, teve como intuito afetar positivamente esse indicador, melhorando a gestão financeira, além de 
possibilitar o levantamento de indicadores de custo mais detalhados. (Fonte: Relatório de Gestão - exercício 2006).

Em 2007 a meta também não foi atingida. O resultado aferido foi menor do que o ano anterior, chegando o custo a $\mathrm{R} \$ 2.068,90$, ficando ainda acima do esperado, $\mathrm{R} \$ 1.820,58$. Havia expectativa de otimização da gestão financeira a partir da implementação do projeto estratégico ‘Avaliação de Custos’. Entretanto, o impacto das ações do referido projeto deve ser sentido a partir de 2008, com a finalização do sistema informatizado específico. (Fonte: Relatório de Gestão - exercício 2007). 


\section{5 - Consolidação dos resultados}

Nos Quadros a seguir são apresentados os resultados de forma integrada, com vistas a proporcionar os elementos quantitativos e qualitativos indispensáveis à avaliação global do processo de gestão estratégica no STJ.

Preliminarmente, nos Quadros 6 e 7, as metas foram apresentadas em termos de resultados obtidos nos diversos indicadores, classificando-se como plenamente alcançada, parcialmente alcançada, ou não alcançada. É apresentada a avaliação anual e a média para todo o período objeto da análise.

Para efeitos dessa classificação, considerou-se plenamente alcançada a meta cujo indicador obteve percentual de cumprimento igual ou superior a 100\% do previsto; parcialmente alcançada aquela cujo indicador apresentou percentual de cumprimento entre 90\%, inclusive, e 100\%; e não alcançada a meta cujo indicador apresentou percentual de cumprimento inferior a 90\%. Para o período completo, foram considerados esses mesmos percentuais, tomando-se como base a média anual observada nos períodos em que os indicadores e metas foram efetivamente avaliados.

A seguir, no Quadro 8, são apresentados os resultados, de forma consolidada por objetivo estratégico, atribuindo-se para cada um deles um grau de verificação em função da média aritmética do percentual de cumprimento das metas e indicadores relacionados a cada objetivo. Similarmente à análise das metas, essa avaliação dos objetivos foi realizada de acordo com o critério a seguir:

- Plenamente alcançado: quando a média aritmética foi superior a 95\%;

- Parcialmente alcançado: quando a média aritmética situou-se de 80 a 95\%;

- Não alcançado: quando a média aritmética situou-se abaixo de 80\%;

O mesmo critério foi utilizado, ainda, para a avaliação dos resultados por perspectiva estratégica, explicitados no Quadro 9.

Finalmente, são apresentadas as análises qualitativas acerca dos resultados e do processo como um todo, inclusive no que diz respeito à continuidade das estratégias ao longo do tempo. 


\begin{tabular}{|c|c|c|c|c|c|c|c|}
\hline \multirow{2}{*}{$\begin{array}{l}\text { Perspectiva } \\
\text { estratégica }\end{array}$} & \multirow{2}{*}{$\begin{array}{c}\text { Objetivo } \\
\text { estratégico }\end{array}$} & \multirow{2}{*}{$\begin{array}{c}\text { Metas e } \\
\text { indicadores }\end{array}$} & \multicolumn{5}{|c|}{ Resultados (percentuais alcançados em relação à meta) } \\
\hline & & & 2004 & 2005 & 2006 & 2007 & Média anual \\
\hline \multirow{5}{*}{ Sociedade } & \multirow{3}{*}{$\begin{array}{l}\text { Oferecer } \\
\text { serviços com } \\
\text { qualidade }\end{array}$} & $\begin{array}{l}\text { Atingir } 90 \% \text { de } \\
\text { satisfação do usuário } \\
\text { externo até } \\
\text { novembro/2005. No } \\
\text { plano de gestão } \\
2006 / 2008 \text { o índice } \\
\text { foi revisado para } \\
80 \%\end{array}$ & $\begin{array}{l}\text { Parcialmente } \\
\text { alcançado } \\
(92,2)\end{array}$ & $\begin{array}{l}\text { Não } \\
\text { Alcançado } \\
(78,3)\end{array}$ & $\begin{array}{l}\text { Não } \\
\text { Alcançado } \\
(86,5)\end{array}$ & $\begin{array}{l}\text { Parcialmente } \\
\text { alcançado } \\
(98,4)\end{array}$ & $\begin{array}{l}\text { Não } \\
\text { Alcançado } \\
(88,9)\end{array}$ \\
\hline & & $\begin{array}{l}\text { Reduzir em } 10 \% \text { a } \\
\text { taxa de } \\
\text { recorribilidade } \\
\text { interna }\end{array}$ & & & $\begin{array}{l}\text { Plenamente } \\
\text { alcançado } \\
(133,0)\end{array}$ & $\begin{array}{l}\text { Plenamente } \\
\text { alcançado } \\
(113,2)\end{array}$ & $\begin{array}{l}\text { Plenamente } \\
\text { alcançado } \\
(123,1)\end{array}$ \\
\hline & & $\begin{array}{l}\text { Reduzir em } 10 \% \text { a } \\
\text { taxa de reforma } \\
\text { interna da decisão } \\
\text { no STJ }\end{array}$ & & & $\begin{array}{l}\text { Não } \\
\text { Alcançado } \\
(58,1)\end{array}$ & $\begin{array}{l}\text { Não } \\
\text { Alcançado } \\
(80,1)\end{array}$ & $\begin{array}{l}\text { Não } \\
\text { Alcançado } \\
(69,1)\end{array}$ \\
\hline & \multirow[b]{2}{*}{$\begin{array}{l}\text { Ampliar a } \\
\text { responsabilidade } \\
\text { sócio ambiental }\end{array}$} & $\begin{array}{l}\text { Reduzir em } 20 \% \text { o } \\
\text { impacto ambiental } \\
\text { causado pelo STJ }\end{array}$ & & & $\begin{array}{l}\text { Parcialmente } \\
\text { alcançado } \\
(92,5)\end{array}$ & $\begin{array}{l}\text { Parcialmente } \\
\text { alcançado } \\
(95,6)\end{array}$ & $\begin{array}{l}\text { Parcialmente } \\
\text { alcançado } \\
(94,0)\end{array}$ \\
\hline & & $\begin{array}{l}\text { Número de pessoas } \\
\text { beneficiadas pelos } \\
\text { projetos de } \\
\text { cidadania ( } 6.000 \\
\text { para 2006 e } 10.000 \\
\text { para 2007) }\end{array}$ & & & $\begin{array}{l}\text { Plenamente } \\
\text { alcançado } \\
(116,06)\end{array}$ & $\begin{array}{l}\text { Plenamente } \\
\text { alcançado } \\
(100,55)\end{array}$ & $\begin{array}{l}\text { Plenamente } \\
\text { alcançado } \\
(108,30)\end{array}$ \\
\hline \multirow{6}{*}{$\begin{array}{l}\text { Processos } \\
\text { internos }\end{array}$} & \multirow{2}{*}{$\begin{array}{l}\text { Elevar a } \\
\text { produção de } \\
\text { julgados }\end{array}$} & $\begin{array}{l}\text { Aumentar a } \\
\text { produção de } \\
\text { julgados em 30\% }\end{array}$ & & $\begin{array}{l}\text { Plenamente } \\
\text { alcançado } \\
(126,7)\end{array}$ & $\begin{array}{l}\text { Não } \\
\text { Alcançado } \\
(65,9)\end{array}$ & $\begin{array}{l}\text { Plenamente } \\
\text { alcançado } \\
(117,5)\end{array}$ & $\begin{array}{l}\text { Plenamente } \\
\text { alcançado } \\
(103,3)\end{array}$ \\
\hline & & $\begin{array}{l}\text { Reduzir o passivo de } \\
\text { processos, (30\% em } \\
2005 \text { e } 25 \% \text { em } \\
2006 \text { e } 2007 \text { ) }\end{array}$ & & $\begin{array}{l}\text { Não } \\
\text { Alcançado } \\
(64,7)\end{array}$ & $\begin{array}{l}\text { Não } \\
\text { Alcançado } \\
(-155,4)\end{array}$ & $\begin{array}{l}\text { Não } \\
\text { Alcançado } \\
(-199)\end{array}$ & $\begin{array}{l}\text { Não } \\
\text { Alcançado } \\
(-96,6)\end{array}$ \\
\hline & \multirow{2}{*}{$\begin{array}{l}\text { Acelerar o } \\
\text { trâmite } \\
\text { processual }\end{array}$} & $\begin{array}{l}\text { Tramitar } 80 \% \text { dos } \\
\text { recursos (agravo e } \\
\text { recurso especial) em } \\
\text { até } 180 \text { dias }\end{array}$ & & $\begin{array}{l}\text { Não } \\
\text { Alcançado } \\
(87,5)\end{array}$ & $\begin{array}{l}\text { Plenamente } \\
\text { alcançado } \\
(100,0)\end{array}$ & $\begin{array}{l}\text { Parcialmente } \\
\text { alcançado } \\
(96,9)\end{array}$ & $\begin{array}{l}\text { Parcialmente } \\
\text { alcançado } \\
(94,8)\end{array}$ \\
\hline & & $\begin{array}{l}\text { Tramitar os } \\
\text { processos } \\
\text { originários em } 90 \\
\text { dias, em média. }\end{array}$ & & & $\begin{array}{l}\text { Não } \\
\text { Alcançado } \\
(68,9)\end{array}$ & $\begin{array}{l}\text { Não } \\
\text { Alcançado } \\
(30,0)\end{array}$ & $\begin{array}{l}\text { Não } \\
\text { Alcançado } \\
(49,4)\end{array}$ \\
\hline & \multirow{2}{*}{$\begin{array}{l}\text { Manter em } \\
\text { patamares } \\
\text { elevados o } \\
\text { conceito do } \\
\text { Tribunal perante } \\
\text { a sociedade }\end{array}$} & $\begin{array}{l}\text { Elevar para } 63 \% \text { a } \\
\text { percepção positiva } \\
\text { da atuação do STJ }\end{array}$ & & & $\begin{array}{l}\text { Parcialmente } \\
\text { alcançado } \\
(92,1)\end{array}$ & & $\begin{array}{l}\text { Parcialmente } \\
\text { alcançado } \\
(92,1)\end{array}$ \\
\hline & & $\begin{array}{l}\text { Elevar para } 30 \% \text { o } \\
\text { índice de } \\
\text { conhecimento } \\
\text { institucional }\end{array}$ & & & $\begin{array}{l}\text { Não } \\
\text { Alcançado } \\
(83,3)\end{array}$ & & $\begin{array}{l}\text { Não } \\
\text { Alcançado } \\
(83,3)\end{array}$ \\
\hline
\end{tabular}

Quadro 6 - Detalhamento das metas e resultados 


\begin{tabular}{|c|c|c|c|c|c|c|c|}
\hline \multirow{2}{*}{$\begin{array}{l}\text { Perspectiva } \\
\text { estratégica }\end{array}$} & \multirow{2}{*}{$\begin{array}{c}\text { Objetivo } \\
\text { estratégico }\end{array}$} & \multirow{2}{*}{$\begin{array}{c}\text { Metas e } \\
\text { indicadores }\end{array}$} & \multicolumn{5}{|c|}{ Resultados (percentuais alcançados em relação à meta) } \\
\hline & & & 2004 & 2005 & 2006 & 2007 & Média anual \\
\hline \multirow{5}{*}{$\begin{array}{l}\text { Aprendizado } \\
\text { e } \\
\text { crescimento }\end{array}$} & \multirow[t]{2}{*}{$\begin{array}{l}\text { Contribuir para } \\
\text { a modernização } \\
\text { do judiciário }\end{array}$} & $\begin{array}{l}\text { Integrar as } \\
\text { informações } \\
\text { processuais de pelo } \\
\text { menos oito } \\
\text { organizações com o } \\
\text { STJ }\end{array}$ & & & $\begin{array}{l}\text { Não } \\
\text { Alcançado } \\
(75,0)\end{array}$ & $\begin{array}{l}\text { Não } \\
\text { Alcançado } \\
(87,5)\end{array}$ & $\begin{array}{l}\text { Não } \\
\text { Alcançado } \\
(81,3)\end{array}$ \\
\hline & & $\begin{array}{l}\text { Garantir } \\
\text { apreciação, nas } \\
\text { comissões do } \\
\text { Congresso } \\
\text { Nacional, de } 80 \% \\
\text { dos projetos de lei } \\
\text { de interesse do STJ }\end{array}$ & & & $\begin{array}{l}\text { Não } \\
\text { Alcançado } \\
(71,4)\end{array}$ & $\begin{array}{l}\text { Alcançado } \\
\text { Plenamente } \\
(107,1)\end{array}$ & $\begin{array}{l}\text { Não } \\
\text { Alcançado } \\
(89,3)\end{array}$ \\
\hline & \multirow[t]{2}{*}{$\begin{array}{l}\text { Desenvolver } \\
\text { competências }\end{array}$} & $\begin{array}{l}\text { Convergir } 100 \% \\
\text { dos processos e } \\
\text { instrumentos } \\
\text { aplicados no } \\
\text { desenvolvimento de } \\
\text { pessoas para o } \\
\text { modelo por } \\
\text { competências }\end{array}$ & & & & $\begin{array}{l}\text { Não } \\
\text { Alcançado } \\
(68,0)\end{array}$ & $\begin{array}{l}\text { Não } \\
\text { Alcançado } \\
(68,0)\end{array}$ \\
\hline & & $\begin{array}{l}\text { Média anual de } \\
\text { horas de } \\
\text { treinamento por } \\
\text { servidor: } 20 \text { horas } \\
\text { em 2005, } 30 \text { horas } \\
\text { em 2006 e } 40 \text { horas } \\
\text { em 2007. }\end{array}$ & $\begin{array}{l}\text { Alcançado } \\
\text { Plenamente } \\
(149,9)\end{array}$ & $\begin{array}{l}\text { Alcançado } \\
\text { Plenamente } \\
(206,3)\end{array}$ & $\begin{array}{l}\text { Alcançado } \\
\text { Plenamente } \\
(123,9)\end{array}$ & $\begin{array}{l}\text { Alcançado } \\
\text { Plenamente } \\
(133,1)\end{array}$ & $\begin{array}{l}\text { Alcançado } \\
\text { Plenamente } \\
(153,3)\end{array}$ \\
\hline & $\begin{array}{l}\text { Melhorar o } \\
\text { clima } \\
\text { organizacional }\end{array}$ & $\begin{array}{l}\text { Obter } 80 \% \text { de } \\
\text { satisfação do } \\
\text { servidor, na } \\
\text { pesquisa de clima } \\
\text { organizacional. }\end{array}$ & $\begin{array}{l}\text { Parcialmente } \\
\text { alcançado } \\
(94,4)\end{array}$ & $\begin{array}{l}\text { Não } \\
\text { Alcançado } \\
(87,4)\end{array}$ & $\begin{array}{l}\text { Não } \\
\text { Alcançado } \\
(87,4)\end{array}$ & $\begin{array}{l}\text { Parcialmente } \\
\text { alcançado } \\
(98,5)\end{array}$ & $\begin{array}{l}\text { Parcialmente } \\
\text { alcançado } \\
(91,9)\end{array}$ \\
\hline \multirow{4}{*}{ Orçamento } & \multirow{4}{*}{$\begin{array}{l}\text { Assegurar e } \\
\text { gerir recursos } \\
\text { orçamentários e } \\
\text { financeiros }\end{array}$} & $\begin{array}{l}\text { Economia de 3\% na } \\
\text { utilização dos } \\
\text { recursos } \\
\text { orçamentários. }\end{array}$ & $\begin{array}{l}\text { Alcançado } \\
\text { Plenamente } \\
(183,0)\end{array}$ & $\begin{array}{l}\text { Não } \\
\text { alcançado } \\
(67,7)\end{array}$ & $\begin{array}{l}\text { Alcançado } \\
\text { Plenamente } \\
(123,3)\end{array}$ & $\begin{array}{l}\text { Alcançado } \\
\text { Plenamente } \\
(116,3)\end{array}$ & $\begin{array}{l}\text { Alcançado } \\
\text { Plenamente } \\
(122,6)\end{array}$ \\
\hline & & $\begin{array}{l}\text { Aplicação dos } \\
\text { recursos } \\
\text { orçamentários: 99\% } \\
\text { em } 2005 \text { e } 100 \% \\
\text { nos anos de } 2006 \text {, } \\
2007 \text { e } 2008 \text {. } \\
\end{array}$ & $\begin{array}{l}\text { Plenamente } \\
\text { alcançado } \\
(100,5)\end{array}$ & $\begin{array}{l}\text { Parcialmente } \\
\text { alcançado } \\
(98,1)\end{array}$ & $\begin{array}{l}\text { Parcialmente } \\
\text { alcançado } \\
(99,2)\end{array}$ & $\begin{array}{l}\text { Parcialmente } \\
\text { alcançado } \\
(99,2)\end{array}$ & $\begin{array}{l}\text { Parcialmente } \\
\text { alcançado } \\
(99,2)\end{array}$ \\
\hline & & $\begin{array}{l}\text { Obter 5\% de } \\
\text { incremento de } \\
\text { recursos para } \\
\text { investimentos entre } \\
\text { os exercícios } \\
\text { financeiros. }\end{array}$ & & & & $\begin{array}{l}\text { Alcançado } \\
\text { Plenamente } \\
(64,31)\end{array}$ & $\begin{array}{l}\text { Alcançado } \\
\text { Plenamente } \\
(64,31)\end{array}$ \\
\hline & & $\begin{array}{l}\text { Diminuir em } 10 \% \text { o } \\
\text { custo do processo } \\
\text { judicial }\end{array}$ & & & $\begin{array}{l}\text { Não } \\
\text { Alcançado } \\
(71,2)\end{array}$ & $\begin{array}{l}\text { Não } \\
\text { Alcançado } \\
(86,4)\end{array}$ & $\begin{array}{l}\text { Não } \\
\text { Alcançado } \\
(78,8)\end{array}$ \\
\hline
\end{tabular}

Quadro 7 - Detalhamento das metas e resultados - continuação 


\begin{tabular}{|c|c|c|c|c|c|c|}
\hline \multirow{2}{*}{$\begin{array}{l}\text { Perspectiva } \\
\text { estratégica }\end{array}$} & \multirow[t]{2}{*}{ Objetivo estratégico } & \multicolumn{5}{|c|}{ Resultados (percentuais alcançados em relação à meta) } \\
\hline & & 2004 & 2005 & 2006 & 2007 & Média anual \\
\hline \multirow{2}{*}{ Sociedade } & $\begin{array}{l}\text { Oferecer serviços com } \\
\text { qualidade }\end{array}$ & $\begin{array}{l}\text { Parcialmente } \\
\text { alcançado } \\
(92,2)\end{array}$ & $\begin{array}{l}\text { Não } \\
\text { Alcançado } \\
(78,3)\end{array}$ & $\begin{array}{l}\text { Parcialmente } \\
\text { alcançado } \\
(92,53)\end{array}$ & $\begin{array}{l}\text { Alcançado } \\
\text { Plenamente } \\
(97,23)\end{array}$ & $\begin{array}{l}\text { Parcialmente } \\
\text { alcançado } \\
(90,06)\end{array}$ \\
\hline & $\begin{array}{l}\text { Ampliar a responsabilidade } \\
\text { sócio ambiental. }\end{array}$ & & & $\begin{array}{l}\text { Alcançado } \\
\text { Plenamente } \\
(104,28)\end{array}$ & $\begin{array}{l}\text { Alcançado } \\
\text { Plenamente } \\
(98,07)\end{array}$ & $\begin{array}{l}\text { Alcançado } \\
\text { Plenamente } \\
(101,17)\end{array}$ \\
\hline \multirow{3}{*}{$\begin{array}{l}\text { Processos } \\
\text { internos }\end{array}$} & $\begin{array}{l}\text { Elevar a produção de } \\
\text { julgados }\end{array}$ & & $\begin{array}{l}\text { Alcançado } \\
\text { Plenamente } \\
(95,7)\end{array}$ & $\begin{array}{l}\text { Não } \\
\text { Alcançado } \\
(-44,75)\end{array}$ & $\begin{array}{l}\text { Não } \\
\text { Alcançado } \\
(-40,75)\end{array}$ & $\begin{array}{l}\text { Não } \\
\text { Alcançado } \\
(3,4)\end{array}$ \\
\hline & $\begin{array}{l}\text { Acelerar o trâmite } \\
\text { processual }\end{array}$ & & $\begin{array}{l}\text { Parcialmente } \\
\text { alcançado } \\
(87,5)\end{array}$ & $\begin{array}{l}\text { Parcialmente } \\
\text { alcançado } \\
(84,45)\end{array}$ & $\begin{array}{l}\text { Não } \\
\text { Alcançado } \\
(63,45)\end{array}$ & $\begin{array}{l}\text { Não } \\
\text { Alcançado } \\
(78,46)\end{array}$ \\
\hline & $\begin{array}{l}\text { Manter em patamares } \\
\text { elevados o conceito do } \\
\text { Tribunal perante a } \\
\text { sociedade }\end{array}$ & & & $\begin{array}{l}\text { Parcialmente } \\
\text { alcançado } \\
(87,7)\end{array}$ & & $\begin{array}{l}\text { Parcialmente } \\
\text { alcançado } \\
(87,7)\end{array}$ \\
\hline \multirow{3}{*}{$\begin{array}{l}\text { Aprendizado e } \\
\text { crescimento }\end{array}$} & $\begin{array}{l}\text { Contribuir para a } \\
\text { modernização do judiciário }\end{array}$ & & & $\begin{array}{l}\text { Não } \\
\text { Alcançado } \\
(73,2)\end{array}$ & $\begin{array}{l}\text { Alcançado } \\
\text { Plenamente } \\
(97,3)\end{array}$ & $\begin{array}{l}\text { Parcialmente } \\
\text { alcançado } \\
(85,25)\end{array}$ \\
\hline & Desenvolver competências & $\begin{array}{l}\text { Alcançado } \\
\text { Plenamente } \\
(149,9)\end{array}$ & $\begin{array}{l}\text { Alcançado } \\
\text { Plenamente } \\
(206,3)\end{array}$ & $\begin{array}{l}\text { Alcançado } \\
\text { Plenamente } \\
(123,9)\end{array}$ & $\begin{array}{l}\text { Alcançado } \\
\text { Plenamente } \\
(100,55)\end{array}$ & $\begin{array}{l}\text { Alcançado } \\
\text { Plenamente } \\
(145,16)\end{array}$ \\
\hline & $\begin{array}{l}\text { Melhorar o clima } \\
\text { organizacional }\end{array}$ & $\begin{array}{l}\text { Parcialmente } \\
\text { alcançado } \\
(94,4)\end{array}$ & $\begin{array}{l}\text { Parcialmente } \\
\text { alcançado } \\
(87,4)\end{array}$ & $\begin{array}{l}\text { Parcialmente } \\
\text { alcançado } \\
(87,4)\end{array}$ & $\begin{array}{l}\text { Alcançado } \\
\text { Plenamente } \\
(98,5)\end{array}$ & $\begin{array}{l}\text { Parcialmente } \\
\text { alcançado } \\
(91,9)\end{array}$ \\
\hline Orçamento & $\begin{array}{l}\text { Assegurar e gerir recursos } \\
\text { orçamentários e financeiros }\end{array}$ & $\begin{array}{l}\text { Alcançado } \\
\text { Plenamente } \\
(141,75)\end{array}$ & $\begin{array}{l}\text { Parcialmente } \\
\text { alcançado } \\
(82,9)\end{array}$ & $\begin{array}{l}\text { Alcançado } \\
\text { Plenamente } \\
(97,9)\end{array}$ & $\begin{array}{l}\text { Parcialmente } \\
\text { alcançado } \\
(91,55)\end{array}$ & $\begin{array}{l}\text { Alcançado } \\
\text { Plenamente } \\
(103,52)\end{array}$ \\
\hline
\end{tabular}

Quadro 8 - Consolidação dos resultados por objetivo estratégico

\begin{tabular}{|c|c|c|c|c|c|}
\hline \multirow{2}{*}{$\begin{array}{l}\text { Perspectiva } \\
\text { estratégica }\end{array}$} & \multicolumn{5}{|c|}{ Resultados (percentuais alcançados em relação à meta) } \\
\hline & 2004 & 2005 & 2006 & 2007 & Média anual \\
\hline Sociedade & $\begin{array}{l}\text { Parcialmente } \\
\text { alcançado } \\
(92,2)\end{array}$ & $\begin{array}{l}\text { Não Alcançado } \\
(78,3)\end{array}$ & $\begin{array}{l}\text { Alcançado } \\
\text { Plenamente } \\
(98,4)\end{array}$ & $\begin{array}{l}\text { Alcançado } \\
\text { Plenamente } \\
(97,65)\end{array}$ & $\begin{array}{l}\text { Parcialmente } \\
\text { alcançado } \\
(91,63)\end{array}$ \\
\hline Processos internos & & $\begin{array}{l}\text { Parcialmente } \\
\text { alcançado } \\
(91,6)\end{array}$ & $\begin{array}{l}\text { Não Alcançado } \\
(42,46)\end{array}$ & $\begin{array}{l}\text { Não Alcançado } \\
(11,35)\end{array}$ & $\begin{array}{l}\text { Não Alcançado } \\
(48,47)\end{array}$ \\
\hline $\begin{array}{l}\text { Aprendizado } \\
\text { crescimento }\end{array}$ & $\begin{array}{l}\text { Alcançado } \\
\text { Plenamente } \\
(122,15)\end{array}$ & $\begin{array}{l}\text { Alcançado } \\
\text { Plenamente } \\
(146,85)\end{array}$ & $\begin{array}{l}\text { Parcialmente } \\
\text { alcançado } \\
(94,83)\end{array}$ & $\begin{array}{l}\text { Alcançado } \\
\text { Plenamente } \\
(98,78)\end{array}$ & $\begin{array}{l}\text { Alcançado } \\
\text { Plenamente } \\
(115,65)\end{array}$ \\
\hline Orçamento & $\begin{array}{l}\text { Alcançado } \\
\text { Plenamente } \\
(141,75)\end{array}$ & $\begin{array}{l}\text { Parcialmente } \\
\text { alcançado } \\
(82,9)\end{array}$ & $\begin{array}{l}\text { Alcançado } \\
\text { Plenamente } \\
(97,9)\end{array}$ & $\begin{array}{l}\text { Parcialmente } \\
\text { alcançado } \\
(91,55)\end{array}$ & $\begin{array}{l}\text { Alcançado } \\
\text { Plenamente } \\
(103,52)\end{array}$ \\
\hline
\end{tabular}

Quadro 9 - Consolidação dos resultados por perspectiva 


\section{6 - Análise do desempenho}

São apresentadas neste tópico as análises dos resultados alcançados em relação às metas fixadas, durante todo o período. As performances são analisadas individualmente, por indicador, e de forma consolidada, por objetivo e perspectiva.

O objetivo estratégico de oferecer serviços com qualidade foi parcialmente alcançado, registrando média percentual de cumprimento de 90,06\%. Apenas a meta relacionada com a redução da taxa de recorribilidade interna foi plenamente alcançada. As metas de satisfação do usuário externo e de redução da taxa de reforma interna, também relacionadas a esse objetivo, não foram alcançadas. Relativamente à satisfação do usuário externo, o resultado foi influenciado pela metodologia adotada na operacionalização da pesquisa, que disponibilizou permanentemente o mesmo questionário na internet, fato que pode ter induzido o usuário externo a usá-lo como canal de reclamações. Já no que se refere à meta de redução da taxa de reforma interna da decisão, os resultados ficaram muito abaixo dos estipulados, em todos os anos. Embora as causas desse desvio ainda estejam sendo analisadas, os baixos níveis registrados sugerem incompatibilidade das metas anuais com as ações programadas, cujos efeitos só ocorrem mais acentuadamente em longo prazo. Nesse caso, poderia ser mais viável estabelecer indicadores anuais escalonados e abrangendo mais de um biênio.

Já o objetivo de ampliar a responsabilidade sócio ambiental foi alcançado plenamente, atingindo média anual de 101,17\% do programado, considerando-se os desempenhos obtidos nas duas metas vinculadas. Merece destaque o resultado alcançado na meta de ampliar o número de pessoas beneficiadas pelos projetos de cidadania, cujo percentual médio anual totalizou 108,30\% do parâmetro previsto, nos dois anos considerados, mesmo elevando a meta no último período. Já a meta de reduzir o impacto ambiental foi parcialmente alcançada, tendo sido detectada a necessidade de aprimorar as ações voltadas para a redução do consumo de energia e de papel.

Considerando a perspectiva sociedade como um todo, que engloba os objetivos de oferecer serviços com qualidade e ampliar a responsabilidade sócio ambiental, os resultados foram parcialmente alcançados. Em que pesem as questões relacionadas à operacionalização de pesquisas, bem como uma possível incompatibilidade da meta no tocante a redução da taxa de reforma interna da decisão, evidenciou-se a necessidade de intensificar os programas e ações relacionados a essa dimensão, definidos no planejamento. Ressalte-se a necessidade de maior articulação dessas ações e programas com os demais 
objetivos do planejamento estratégico, sobretudo os relacionados aos processos internos, ao desenvolvimento de competências e à modernização do judiciário.

O objetivo estratégico de elevar a produção de julgados não foi alcançado. A meta de aumentar a quantidade de julgados foi plenamente alcançada em 2005 e 2007, com uma queda em 2006, justificada pela greve dos servidores e pela demora na substituição de quatro ministros aposentados no período. Entretanto, no que se refere à meta de reduzir o passivo de processos do tribunal, também relacionada a esse objetivo, os resultados ficaram muito abaixo do planejado em todos os anos, mesmo tendo havido redução do limite estipulado inicialmente, de 30\% para 25\%. Conseqüentemente, a média percentual de cumprimento desse objetivo situou-se apenas em 3,4\%. Ressalte-se que, no tocante a meta reduzir o passivo de processos, o resultado também foi influenciado em 2006 pela greve dos servidores e pela demora na substituição de quatro ministros. Entretanto, o principal fator que influenciou o não cumprimento dessa meta, em todos os anos analisados, foi o aumento massivo da demanda de processos que chega ao Tribunal. A administração vem agindo desde 2006 no sentido de priorizar ações que impactam diretamente essa meta. Entre elas está à criação do Núcleo de Agravos da Presidência, para processar aqueles manifestamente inadmissíveis, além da lei que dispõe sobre a incidência de custas pela prestação de serviços forense do Tribunal, regulamentada em 2008. Nesse caso, poderia ser mais viável analisar os resultados de 2008 para verificar se as medidas adotadas surtiram efeito positivo ou se há necessidade de estabelecer novos indicadores.

\section{O objetivo estratégico de acelerar o trâmite processual não foi alcançado,} atingindo média anual de 78,46\% do programado, já considerados os desempenhos obtidos nas duas metas a ele vinculadas. A meta de tramitar $80 \%$ dos recursos em até 180 dias, não foi atingida em 2005, alcançando o nível de 87,5\% do programado. Em 2006 a meta foi cumprida e, em 2007, o percentual foi revisto, passando de 80\% para 64\%. Mesmo com essa redução, a meta não foi cumprida. O aumento da demanda foi apontado como o principal entrave ao alcance dessa meta. Além disso, consta no Relatório de 2007 que alguns Ministros atuaram prioritariamente na eliminação de processos antigos e mais complexos, que levam um prazo mais elevado para ser solucionados, gerando efeitos na contagem tempo de tramitação. A outra meta vinculada ao objetivo era tramitar os processos originários em 90 dias, em média. A sua mensuração ficou prejudicada no primeiro ano (2005), por terem sido necessários procedimentos para mapear os prazos fora do STJ. Em 2006 e 2007 a meta não foi cumprida e o motivo, a exemplo da meta anterior, foi a atuação de alguns ministros nos processos antigos, 
fato que aumenta o tempo de tramitação.

O objetivo de manter em patamares elevados o conceito do Tribunal perante a sociedade foi alcançado parcialmente, atingindo $87,7 \%$ do percentual estabelecido. Esse objetivo está associado a duas metas. Uma delas é elevar para 63\% a percepção positiva da atuação do STJ, cuja primeira mensuração ocorreu em 2006 por meio de uma pesquisa aplicada nas cinco regiões do País. A meta foi parcialmente atingida, obtendo-se o resultado de 92,2\% do programado, servindo de levantamento da situação inicial e parâmetro para as ações de melhoria. Em 2007 uma decisão administrativa definiu que a meta seria avaliada de dois em dois anos. A outra meta era elevar para 30\% o índice de conhecimento institucional, tendo sido criada em 2006 e cuja mensuração se deu por meio da mesma pesquisa da meta anterior. O resultando não foi alcançado, atingindo-se 83,3\% do programado. Em 2007, uma decisão administrativa definiu que esta meta também seria avaliada de dois em dois anos.

Considerando a perspectiva processos internos como um todo, que engloba os objetivos de elevar a produção de julgados, acelerar o trâmite processual e manter em patamares elevados o conceito do Tribunal perante a sociedade, os resultados não foram alcançados. O desempenho nessa perspectiva foi fortemente influenciado por fatores externos, ligados à demora na substituição de ministros, ao aumento de processos em tramitação e à elevação da demanda perante o Judiciário, bem como por fatores pontuais relacionados à greve de servidores e atuação em processos mais antigos e complexos. Evidencia-se, contudo, a necessidade de definição de ações de caráter continuado para fazer frente a esses objetivos, com metas escalonadas de longo prazo. Considerando que os objetivos relacionados a esta dimensão estratégica têm forte impacto no desempenho institucional do STJ, mostra-se necessária também uma maior articulação interna e externa em torno das ações e programas a ele relacionados.

O objetivo estratégico de contribuir para a modernização do judiciário foi parcialmente alcançado, registrando média percentual de cumprimento de $85,5 \%$. A meta de integrar as informações processuais de pelo menos oito organizações com o STJ não foi alcançada, atingindo $81,3 \%$ do programado nos dois anos que foram analisados. A dificuldade apresentada para o alcance da meta foi atribuída à disponibilidade e interesse dos Tribunais para adoção dos procedimentos de integração apresentados pelo STJ. A meta de garantir apreciação nas comissões do Congresso Nacional de $80 \%$ dos projetos de lei de interesse do STJ não foi alcançada em 2006. No entanto, em 2007 a meta foi alcançada 
plenamente.

O objetivo de desenvolver competências foi plenamente alcançado, atingindo média 145,6\% no período analisado, considerados os desempenhos obtidos nas duas metas vinculadas a esse quesito. A meta de convergir 100\% dos processos e instrumentos aplicados no desenvolvimento de pessoas para o modelo por competências não foi alcançada em 2007. O principal motivo apontado para o não cumprimento foi a dificuldade de integração do software adquirido para implantar a gestão por competências com os sistemas existentes no Tribunal. Já a meta de horas de treinamento por servidor foi plenamente alcançada em todos os anos, mesmo considerando-se as revisões dos percentuais estabelecidos: 20h/servidor em 2005; 30h/servidor em 2006; e 40h/servidor em 2007. Essa performance evidencia a prioridade que vem sendo atribuída pelo Tribunal ao investimento na capacitação de seu corpo de servidores e ao modelo de gestão por competências.

O objetivo estratégico de melhorar o clima organizacional foi parcialmente alcançado. Esse objetivo envolve apenas uma meta: obter $80 \%$ de satisfação do servidor na pesquisa de clima organizacional. O resultado alcançado situou-se em 91,9\% do parâmetro estabelecido. Em resposta ao não atendimento da meta em sua plenitude, foi criado um comitê gestor do clima, que se reúne mensalmente e tem adotado ações de melhoria nos fatores comunicação, gestão de processos, liderança, condições ambientais, relacionamento e motivação.

Considerando a perspectiva aprendizado e crescimento como um todo, que engloba os objetivos de contribuir para a modernização do judiciário, desenvolver competências e melhorar o clima organizacional, o resultado foi alcançado plenamente, atingindo 115,65\% em média. Essa performance foi determinada, principalmente, pelo desempenho no quesito relacionado a horas de treinamento, que é vinculado ao objetivo de desenvolver competências e cujo resultado situou-se muito acima do esperado. Esse esforço no sentido de sensibilizar o quadro de servidores, através do treinamento e de outras ferramentas aplicáveis, para o desenvolvimento de competências, certamente terá impacto positivo sobre o desempenho dos demais objetivos e perspectivas estratégicas. Esse efeito ainda não pôde ser verificado no período de abrangência deste estudo, já que coincidiu com a fase a implementação dos demais programas e ações vinculados aos demais objetivos estratégicos. É de se esperar, contudo, um significativo impacto nos períodos subseqüentes, desde que as ações apresentem continuidade. 
foi plenamente alcançado, atingindo índice de $103,52 \%$ do planejado, já englobando o resultando das quatro metas vinculadas. A meta de economizar 3\% na utilização dos recursos orçamentários foi plenamente alcançada em 2004, 2006 e 2007. As metas de aplicar 99\% dos recursos orçamentários em 2004 e 2005, e 100\% em 2006 e 2007, também tiveram desempenho satisfatório. Em 2004 o resultado foi plenamente alcançado e a média anual de cumprimento, considerando-se todo o período, situou-se em 99,2\%. A meta de incrementar os recursos para investimentos em 5\%, com relação ao exercício anterior, através da implementação de ações estratégicas, não foi atingida em 2006. No primeiro semestre de 2007 foi implementado o Escritório Corporativo de Projetos do STJ, que visa corrigir as distorções relacionadas ao controle orçamentário dos projetos. Em 2007 a meta foi atingida, superando em muito o estabelecido, totalizando 64\% de incremento, comparativamente aos 5\% fixados. Finalmente, a meta anual de diminuir em $10 \%$ o custo do processo judicial, até dezembro/2007, não foi alcançada nos anos analisados. O percentual médio de cumprimento da meta situou-se em 78,8\%. Com o intuito de aperfeiçoar o gerenciamento desse indicador, foi iniciada em 2007 a implantação do projeto de Avaliação de Custos, proporcionando melhorias na gestão financeira e possibilitando o levantamento de indicadores de custo mais detalhados. O projeto não chegou a ser concluído em 2007 e o impacto das ações deverá ser visualizado a partir de 2008.

Conseqüentemente, foram plenamente alcançados os resultados vinculados à perspectiva orçamento, que envolve apenas esse objetivo estratégico o de assegurar e gerir recursos orçamentários e financeiros. O desempenho obtido nessa dimensão estratégica evidencia eficiência na utilização dos recursos públicos no âmbito do STJ. Ressalte-se, todavia, o baixo resultado alcançado com relação ao objetivo de reduzir o custo do processo judicial, indicador de grande importância e visibilidade no tocante à atuação do Tribunal. Entretanto, é importante notar que houve pronta reação visando reverter esse desempenho através das ações corretivas, que certamente irão influenciar os resultados dos períodos posteriores. Essa correção de rumos é um importante indicativo da aplicação dos princípios da Administração Estratégica, na prática. 


\section{5 - Conclusão}

Procurou-se avaliar neste trabalho os resultados obtidos na gestão estratégica do STJ, bem como a sua efetividade. Mesmo considerando as dificuldades na aferição de alguns indicadores e levando-se em conta o período de abrangência reduzido, foi possível deduzir um quadro avaliativo global para o período de 2004 a 2007, que retrata não só efeito da gestão estratégica sobre o desempenho da Instituição, bem como a sua utilização na prática como instrumento capaz de viabilizar o cumprimento de sua missão institucional. O ano de 2008 não foi abrangido pela análise, tendo em vista que o relatório de gestão desse período ainda não está disponível.

Inicialmente foram analisados os resultados obtidos em cada uma das vinte metas estabelecidas no planejamento, atribuindo-se o índice de cumprimento de cada uma delas em relação ao programado. A seguir, os resultados foram agrupados, atribuindo-se os índices de desempenho para cada um dos nove objetivos estratégicos que abrangem aquelas metas. Finalmente, foram atribuídos os índices de desempenho em nível de perspectiva, segundo a classificação observada no planejamento, a saber: “Orçamento”, “Aprendizado e Crescimento”, “Sociedade” e "Processos Internos”. Os resultados foram analisados em bases anuais e considerando a média do período.

Os resultados foram plenamente alcançados no que se refere às perspectivas estratégicas “Aprendizado e Crescimento” e “Orçamento”. Os resultados vinculados à perspectiva "Sociedade” foram alcançados parcialmente e os relacionados com "Processos Internos”, por sua vez, não foram alcançados.

Em termos de desempenho global, considerando as quatro perspectivas, a média anual dos resultados alcançados situou-se em $89,8 \%$ do programado.

As perspectivas estratégicas que tiveram seus resultados plenamente alcançados (Aprendizado e Crescimento e Orçamento) são os que estão mais diretamente vinculados a ações diretas do Tribunal, com menor grau de interveniência externa. Destacam-se os desempenhos acima do esperado no tocante aos objetivos de desenvolver competências e de aperfeiçoar e otimizar a gestão dos recursos orçamentários. Ressalte-se que os resultados alcançados nesses objetivos certamente terão importância significativa sobre o desempenho dos demais objetivos e perspectivas estratégicas, para períodos subseqüentes, considerando o efeito intertemporal das ações e programas implementados. Mesmo assim, alguns objetivos relacionados à perspectiva estratégica “Aprendizado e Crescimento” ainda apresentaram 
desempenho parcialmente alcançado, a exemplo da melhoria do clima organizacional. Além disso, embora na perspectiva estratégica “Orçamento” o único objetivo a ela vinculado tenha apresentado desempenho global de plenamente alcançado, a meta diminuir em $10 \%$ o custo do processo judicial não foi alcançada nos anos analisados.

Com relação à perspectiva estratégica “Sociedade”, os resultados foram influenciados por questões operacionais e metodológicas verificadas na pesquisas de satisfação do usuário externo e por uma possível incompatibilidade da meta de redução da taxa de reforma interna da decisão. Mesmo assim, evidenciou-se a necessidade de intensificar os programas e ações relacionados a essa dimensão, bem como a necessidade de maior articulação dessas ações e programas com os demais objetivos do planejamento estratégico.

Já no tocante à perspectiva estratégica "Processos Internos” o fraco desempenho foi influenciado por fatores externos, tais como a demora na substituição de ministros, aumento de processos em tramitação e à elevação da demanda perante o Judiciário, bem como por fatores pontuais, tais como greve de servidores e atuação em processos mais antigos e complexos. Evidencia-se, contudo, a necessidade de definição de ações de caráter continuado para fazer frente a esses objetivos, com metas escalonadas de longo prazo. Considerando que os objetivos relacionados a esta dimensão estratégica têm forte impacto no desempenho institucional do STJ, mostra-se necessária também uma maior articulação interna e externa em torno das ações e programas a ele relacionados.

A gestão estratégica no STJ vem sendo conduzida com efetividade e aplicação dos aspectos metodológicos recomendáveis. Todavia, é necessário que o processo de gestão estratégica e as ações dela resultantes apresentem continuidade e que os diversos objetivos sejam tratados de forma integrada. Nesse sentido, cabe destacar a utilização, pelo STJ, do Balanced Scorecard, ferramenta de gerenciamento e aferição da gestão estratégica, cuja aplicação vem possibilitando essa visualização integrada dos resultados e a pronta adoção de ações corretivas.

Por fim, cabe destacar a importância de se intensificarem ações voltadas para a divulgação interna dos resultados obtidos em nível de metas, objetivos e perspectiva, de forma a obter o envolvimento e articulação de todas as áreas do STJ no processo de planejamento e gestão estratégica, bem como uma maior participação e comprometimento dos servidores nas ações e programas deles decorrentes. 


\section{REFERÊNCIAS}

ALBERTON, L. Análise da implantação da qualidade total em uma instituição pública de educação. 1999. Dissertação (Mestrado em Eng. de Produção) - Universidade Federal de Santa Catarina. Disponível em <http: //www.eps.ufsc.br/disserta99/alberton/cap5.html>. Acesso em: 9 set. 2008.

CARBONE, P. P. et al. Gestão por competências e gestão do conhecimento - 2. ed. - Rio de Janeiro: FGV, 2006

CHIAVENATO, I., 1929 - Planejamento Estratégico / Idalberto Chiavenato, Arão Sapiro. Rio de Janeiro: Elsevier, 2003

FREITAS, M. E. Cultura Organizacional: evolução e crítica. São Paulo: Thomson Learning, 2007.

GODOY, A. S. Introdução à pesquisa qualitativa e suas possibilidades. Revista de Administração de Empresas. São Paulo, v. 35, n. 2, p. 57-63, mar/abr. 1995.

GODOY, A. S. A pesquisa qualitativa e sua utilização em administração de empresas. Revista de Administração de Empresas. São Paulo, v. 35, n. 4, p. 65-71, jul/ago. 1995.

GÜNTHER, H. Pesquisa qualitativa versus pesquisa quantitativa: Esta É a Questão? Psicologia: Teoria e Pesquisa.Brasília, v.22, n. 2, p. 201 - 210, maio/ago 2006.

KAPLAN, R. S.; NORTON, D. P. A Estratégia em Ação: Balanced Scorecard. Tradução Luiz Euclydes Trindade Frazão Filho. Rio de Janeiro: Campus, 1997.

Mapas estratégicos convertendo ativos intangíveis em resultados tangíveis. Tradução Afonso Celso da Cunha Serra. 8. ed. Rio de Janeiro: Elsevier, 2004.

KOTTER, J. P., 1947 - Liderando mudança/John P. Kotter; tradução Fallow-Up Traduções e Assessoria de Informática. - 6. ed. Rio de Janeiro: Campos, 1997

KUNSCH, Margarida M. Krohling. Planejamento e gestão estratégica de relações públicas nas organizações contemporânea, Análisi, São Paulo, v. 34, p. 125-139 2006.

LEAL FILHO, J. G. Aprendizagem organizacional e gestão estratégica participativa: Teoria e prática para criação de organizações que aprendem. - Curitiba: Juruá Editora, 2005.

LEITÃO, D. M. Administração estratégica; abordagem conceitual e atitudinal. Rio de Janeiro: SENAI/DN, PETROBRAS, 1995. 
LÜDKE, M.; ANDRÉ, M. L. Métodos de coleta de dados: observação, entrevista e análise documental. In: Pesquisa em educação: abordagens qualitativas. 6 reimp. São

Paulo: EPU, 1986.

MINTZBERG, H.. Safári de estratégia: um roteiro pela selva do planejamento estratégico / Henry Mintzberg, Bruce Ahlstrand, Joseph Lampel: trad. Nivaldo Montingelli Jr. - Porto Alegre: Bookman. 2000.

OLIVEIRA, D. P. R. Planejamento estratégico: conceitos, metodologia e práticas. 21. ed. - São Paulo: Atlas, 2004.

PRIETO, V. C. et. al. Fatores Críticos na implementação do Balanced Scorecard. Gestão \& Produção. v.13, n.1, p.81-92, jan.-abr. 2006

REZENDE, J. F. Balanced Scorecard e a gestão do Capital intelectual: Alcançando a performance balanceada na economia do conhecimento. 2a . ed. Rio de Janeiro: Elsevier, 2003.

SENGE, P. M. et. al. A dança das mudanças/Peter Senge; tradução de Bazán Tecnologia i Lingüística. - Rio de Janeiro: Campos, 1999 Tradução de The dance of change 1. Mudança organizacional.

SILVEIRA JÚNIOR, A.; VIVACQUA, G. Planejamento Estratégico como Instrumento de Mudança Organizacional. 2. ed. São Paulo: Atlas, 1999.

SINOTTI, J. Balanced Scorecard Um resumo dos principais conceitos Disponível em: HTTP://www.terraforum.com.br/sites/terraforum/paginas/biblioteca/bsc.aspx - 27k Acesso em 31/10/2008.

SUPERIOR TRIBUNAL DE JUSTIÇA (Brasil). Plano Estratégico: 2004 - 2006. Brasília, 2004. 33 p.

SUPERIOR TRIBUNAL DE JUSTIÇA (Brasil). Plano de Gestão: 2006 - 2008. Brasília, 2006. 49 p.

SUPERIOR TRIBUNAL DE JUSTIÇA (Brasil). Relatório de Gestão: 2005. Brasília, 2006. 78 p.

SUPERIOR TRIBUNAL DE JUSTIÇA (Brasil). Relatório de Gestão: 2006. Brasília, 2007. $143 \mathrm{p}$.

SUPERIOR TRIBUNAL DE JUSTIÇA (Brasil). Relatório de Gestão: 2007. Brasília, 2008. $139 \mathrm{p}$.

SUPERIOR TRIBUNAL DE JUSTIÇA (Brasil). Plano de Gestão Relatório de Desempenho - 
Ago/2006. Brasília, 2006. 33 p.

SUPERIOR TRIBUNAL DE JUSTIÇA (Brasil). Plano de Gestão Relatório de Desempenho Set/2006. Brasília, 2006. 33 p.

SUPERIOR TRIBUNAL DE JUSTIÇA (Brasil). Plano de Gestão Relatório de Desempenho Out/2006. Brasília, 2006. 33 p.

SUPERIOR TRIBUNAL DE JUSTIÇA (Brasil). Plano de Gestão Relatório de Desempenho Nov/Dez/2006. Brasília, 2006. 33 p.

SUPERIOR TRIBUNAL DE JUSTIÇA (Brasil). Plano de Gestão Relatório de Desempenho Jan/2007. Brasília, 2007. 33 p.

SUPERIOR TRIBUNAL DE JUSTIÇA (Brasil). Plano de Gestão Relatório de Desempenho Fev/2007. Brasília, 2007. 33 p.

SUPERIOR TRIBUNAL DE JUSTIÇA (Brasil). Plano de Gestão Relatório de Desempenho Mar/2007. Brasília, 2007. 32 p.

SUPERIOR TRIBUNAL DE JUSTIÇA (Brasil). Plano de Gestão Relatório de Desempenho Abr/2007. Brasília, 2007. 32 p.

SUPERIOR TRIBUNAL DE JUSTIÇA (Brasil). Plano de Gestão Relatório de Desempenho Mai/2007. Brasília, 2007. 32 p.

SUPERIOR TRIBUNAL DE JUSTIÇA (Brasil). Plano de Gestão Relatório de Desempenho Jun/2007. Brasília, 2007. 8 p.

SUPERIOR TRIBUNAL DE JUSTIÇA (Brasil). Plano de Gestão Relatório de Desempenho Jul/2007. Brasília, 2007. 8 p.

SUPERIOR TRIBUNAL DE JUSTIÇA (Brasil). Plano de Gestão Relatório de Desempenho Ago/2007. Brasília, 2007. 9 p.

SUPERIOR TRIBUNAL DE JUSTIÇA (Brasil). Plano de Gestão Relatório de Desempenho Set/2007. Brasília, 2007. 8 p.

SUPERIOR TRIBUNAL DE JUSTIÇA (Brasil). Plano de Gestão Relatório de Desempenho Out/2007. Brasília, 2007. 7 p.

SUPERIOR TRIBUNAL DE JUSTIÇA (Brasil). Plano de Gestão Relatório de Desempenho Nov/2007. Brasília, 2007. 9 p. 
SUPERIOR TRIBUNAL DE JUSTIÇA (Brasil). Plano de Gestão Relatório de Desempenho Dez/2007. Brasília, 2007. 8 p. 
Anexo A- Mapa estratégico do Plano de Gestão 2004-2006

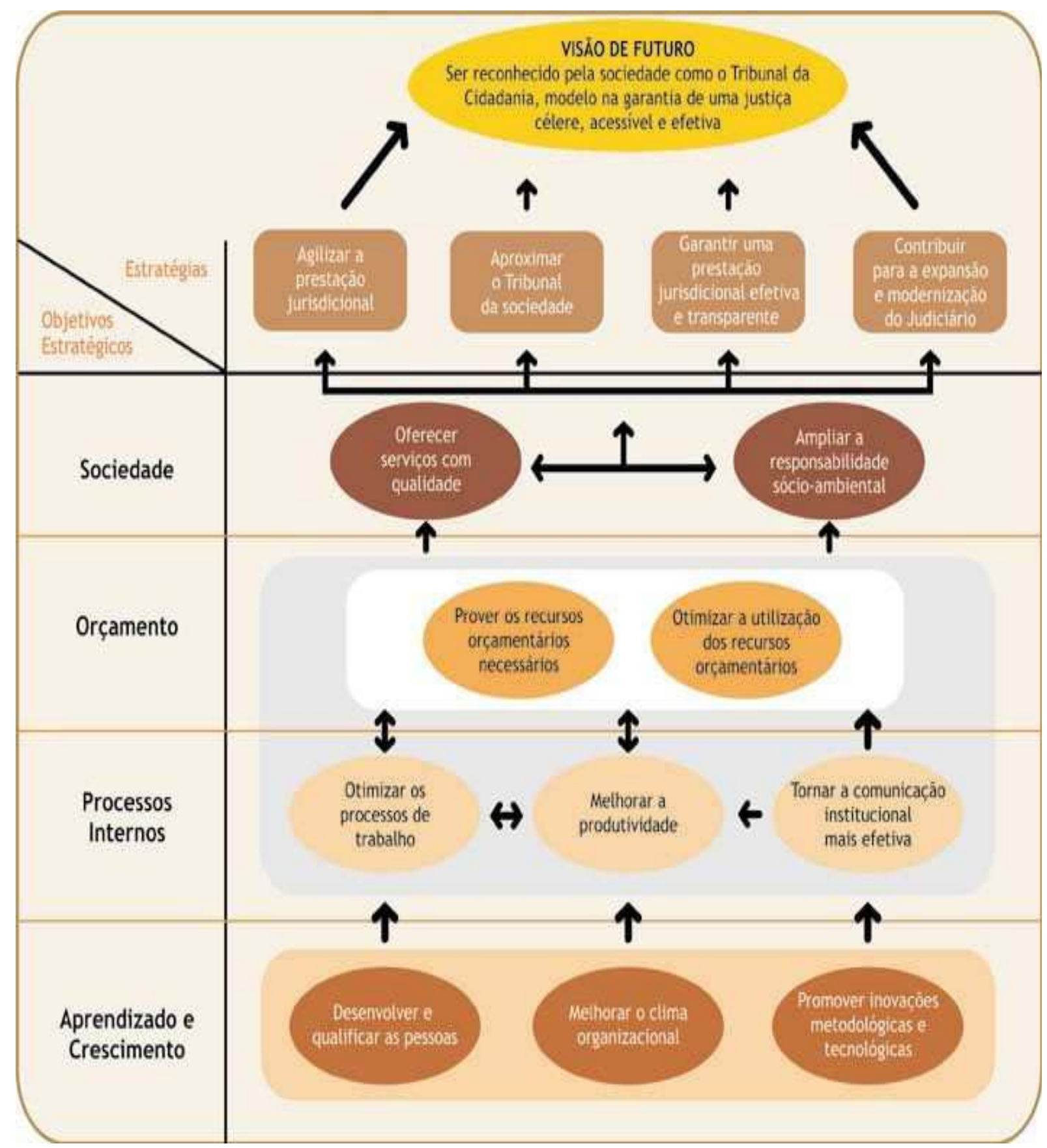

Fonte - Plano de Gestão 2004 - 2006 
Anexo B - Mapa estratégico do Plano de Gestão 2006-2008

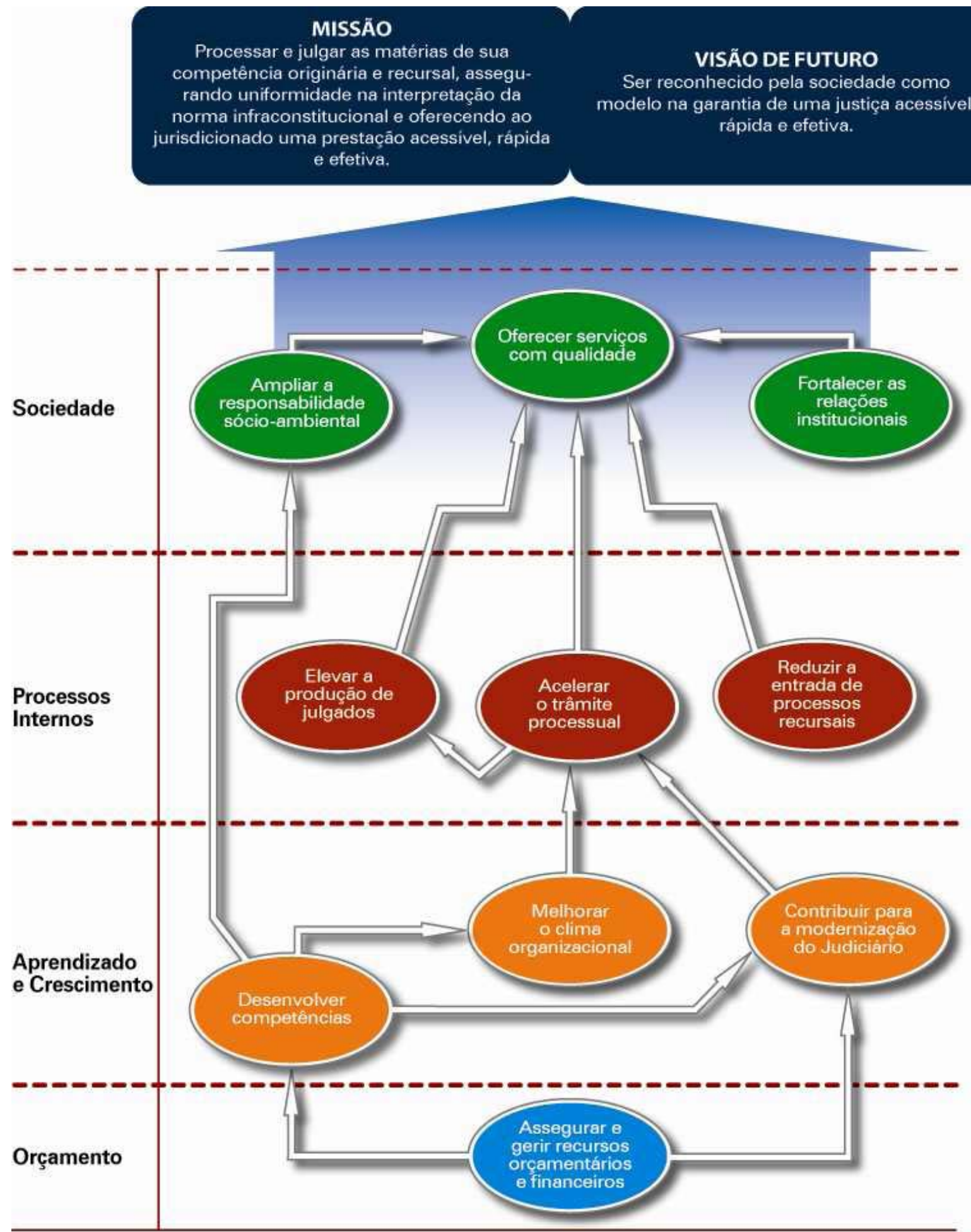

Fonte - Plano de Gestão 2006 - 2008 


\section{Anexo C - Estrutura Básica do Superior Tribunal de Justiça}

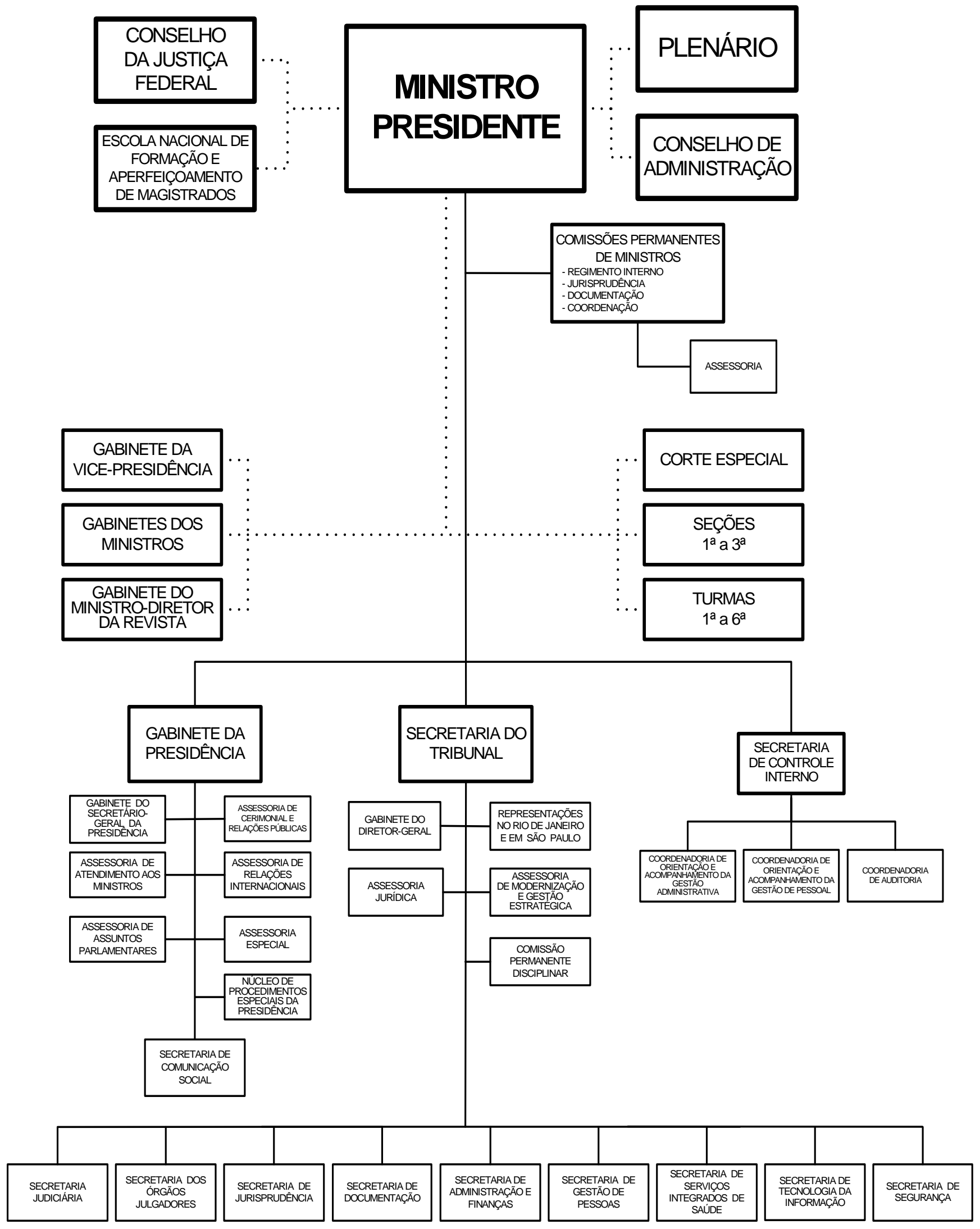

Fonte - Relatório de Gestão Exercício 2007. 